\title{
Late Victorian Sexuality and Spiritualism: The Place of the Paranormal in Queer Erotic Partnerships
}

\author{
Sharon E. Kelly
}

Follow this and additional works at: https://researchrepository.wvu.edu/etd

\section{Recommended Citation}

Kelly, Sharon E., "Late Victorian Sexuality and Spiritualism: The Place of the Paranormal in Queer Erotic Partnerships" (2018). Graduate Theses, Dissertations, and Problem Reports. 5960.

https://researchrepository.wvu.edu/etd/5960

This Dissertation is protected by copyright and/or related rights. It has been brought to you by the The Research Repository @ WVU with permission from the rights-holder(s). You are free to use this Dissertation in any way that is permitted by the copyright and related rights legislation that applies to your use. For other uses you must obtain permission from the rights-holder(s) directly, unless additional rights are indicated by a Creative Commons license in the record and/ or on the work itself. This Dissertation has been accepted for inclusion in WVU Graduate Theses, Dissertations, and Problem Reports collection by an authorized administrator of The Research Repository @ WVU.

For more information, please contact researchrepository@mail.wvu.edu. 


\title{
Late Victorian Sexuality and Spiritualism: \\ The Place of the Paranormal in Queer Erotic Partnerships
}

\author{
Sharon E. Kelly \\ Dissertation submitted \\ to the Eberly College of Arts and Sciences \\ at West Virginia University \\ in partial fulfillment of the requirements for the degree of \\ Doctor of Philosophy in \\ English Literature
}
Dennis Allen, Ph.D., Chair
John Lamb, Ph.D.
Lisa Weihman, Ph.D.
Ryan Claycomb, Ph.D.
Lisa DiBartolomeo, Ph.D.
Department of English

Morgantown, West Virginia

2018

Keywords: Victorian, fin de siècle, Queer Theory, Sexuality Studies, Identity, Spiritualism, Mesmerism, Possession Copyright 2018 Sharon E. Kelly 


\title{
ABSTRACT \\ Late Victorian Sexuality and Spiritualism: The Place of the Paranormal in Queer Erotic Partnerships
}

\begin{abstract}
Sharon E. Kelly
This dissertation argues that fin de siècle navigations of emerging categories of sexual identity were partially expressed in literary representations of supernatural connections, transformations, events, and practices. I build on Sexuality Studies and Queer Theory foundations by such scholars as Foucault, Halberstam, and Warner along with New Historicist scholarship about spiritualism in the nineteenth century to examine the connections between aberrant erotic desires and alternative forms of spirituality. Through readings of the anonymous Teleny (1893), Oscar Wilde's The Picture of Dorian Gray, Richard Marsh's The Beetle, and the poetry of Michael Field, I assert that queer sexual identities and acts, unspeakable, unfixed, and nebulous in the late Victorian years, were supported, represented, and navigated in these works through the use of spiritualism of various kinds. I conclude my project by examining how the Neo-Victorian Showtime series Penny Dreadful (2014-2016) reshapes Victorian practices into a new resource for the modern LGBTQ + community, demonstrating the continuing importance of spiritualism and sexual desire in non-traditional identity and relationship building.
\end{abstract}




\section{Acknowledgements}

To Dennis Allen, whose humor, frankness, and guidance have helped me through the $\mathrm{PhD}$ process both intellectually and emotionally. I am so grateful to have had such a down-toearth mentor whose levity made this whole process as enjoyable as it could have been. Thanks, $\mathrm{D}$, for helping me realize I can do theory, and that scholarship can be fun.

To my committee: John Lamb, Lisa Weihman, Ryan Claycomb, and Lisa DiBartolomeo. Your varied expertise helped push me beyond the center of the Venn diagram of our interests, and this project is the stronger for it. You encouraged me to think of new things and in new ways, polished my prose, and helped me identify patterns and habits in my writing. Thanks for celebrating my strengths and helping me improve my weaknesses.

To WVU's English Department, whose Graduate Teaching Assistant positions and Ludlum Doctoral Fellowship award financed my professional development and my research.

To Danielle Petrak, whose chance call for applications from the English department led me to five summers with the Watts Museum and a wonderful friendship. I'm so thankful for how flexible you were as a boss and how enthusiastic you've always been about my work. I hope I can be as supportive of your $\mathrm{PhD}$ program as you were of mine.

To Dr. Valerie Ann Surrett, who constantly inspires me with her composure and professionalism, her fun research interests, and ability to juggle life and scholarship. Our crafternoons have kept me sane, and I'm so glad we were put in G23 together all those years ago.

To Maria Barron, whose other Victorian interests made for some wild conversations about sex, magic, trauma, and country houses. Your contemporary popular lit recommendations are always stellar, and helped me stay balanced while I worked on this dissertation. From the beginning of our program and coursework, when we were roommates, lifting buddies, and cackling banshees in the classroom, through the dissertation process and planning a wedding, you've been my rock. Thanks.

To Rebecca Norton, who was always curious about my research and willing to listen to me ramble about the most recent cool thing I read. RAN, our love inspired Chapter 4.

To my sister Susan, whose perspectives on LGBTQ issues and language has been invaluable, and whose insightful and probing questions about Queer Theory have helped me understand it and her and myself a little better. Thanks, Sus, for helping me be a better person, and for encouraging me to bring my academic interests more directly into conversation with daily life. 
To my parents, Donna and Phil, without whose support I would not have been able to complete this project. Thank you for the emotional, intellectual, and sometimes financial boost - you have always been there for me, no matter which I needed. Thank you for understanding when work didn't allow me to come home for a visit, and thank you for always welcoming me home when it was possible. Thank you for your confidence, and for sharing in my joy. Read this at your own risk.

To my husband, John. We met while I was in coursework, moved in together when I was preparing for book list exams, and planned a wedding in the middle of my dissertation-I'm so excited to see where life takes us now. Thank you for your eternal patience when I had intense writing days and was completely anti-social. Thank you for listening to me talk about gay sex and mesmerism and all sorts of things. Thank you for good-naturedly promising to read The Beetle and everything else I told you you just absolutely must read. Thank you for feeding me, and for supporting us financially. Thank you for your unconditional love and for always being "impressed, but not surprised" by my accomplishments - thanks for your confidence in me. 


\section{Table of Contents}

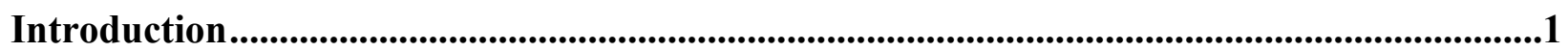

Sex and Magic

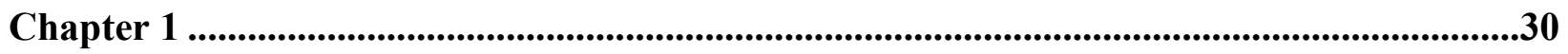

Teleny, Telepathy, and the Gay Counterpublic

Chapter 2

Possession and The Picture of Dorian Gray: "The Terrible Pleasure of a Double Life"

Chapter 3 .

The Beetle's Mesmeric Language of Queer Desire

Chapter 4 .

The Aesthetic Marriage of Michael Field

Chapter 5 .

Identity in Penny Dreadful: "Without Limits"

Epilogue

Have a Cigarette

Works Cited. 


\section{INTRODUCTION: SEX AND MAGIC}

"Then—in the very midst of my vision—-the pianist turned his head and cast one long, lingering, slumberous look at me, and our glances met again. But was he the pianist, was it Antinoüs, or rather, was he not one of those two angels which God sent to Lot? Anyhow, the irresistible charm of his beauty was such that I was quite overcome by it" (Teleny 7). Thus says Des Grieux, in describing his first encounter with the musician Teleny, shortly before he and the piano's tune climax together in mystical union. Teleny's inspired playing is "entrancing," "enthralling," and has a "sensual element" that causes the vision Des Grieux describes above (5). Because “a latent spell [...] pervades every song,” Des Grieux can experience an erotic crescendo along with Teleny's musical one, but he is unsure what, exactly, holds power over him. Des Grieux narrates, "I was spell-bound; yet I could hardly tell whether it was with the composition, the execution, or the player himself" (6). Teleny, the anonymously-published gay erotic novel of 1893, explores the question of being "spell-bound" by same-sex desire as Des Grieux gradually comes to accept his attraction for the pianist behind the music. As illustrated by this early scene, the theme of same-sex desire is intrinsically linked to unexplainable experiences or supernatural occurrences. In addition to new sensations of desire, Teleny inspires repeated visions in Des Grieux. He struggles with his passion for the young musician, although it is ultimately irresistible — in part because of their supernatural connection.

The opening quote here demonstrates the important overlap of spiritualism and sexuality during the fin de siécle, which is the main focus of this project. For example, the vision centers on the Roman emperor Hadrian's friend, advisor, and lover, Antinoüs, who the novel suggests 
died for Hadrian's love. ${ }^{1}$ In the real world of the concert hall, Teleny's "slumberous look" operates in two ways: first, "slumberous" brings to mind the bed(room) and associated private sexual activity. Second, "slumberous" could mean a half-awake, trance-like state akin to hypnosis - a word grounded in the Greek word for sleep. Language that conflates the sexual and spiritual abounds in Teleny, such as when the narrator calls semen "holy water" (122), and the novel inspired me to investigate other literature that explores queer desire and the supernatural. Why, I wondered, is the literary use of paranormal events or powers tied so closely to desire? What does alternative spirituality do for alternative sexuality? In the case of Teleny, the two are linked as community- and identity-building factors that help Des Grieux navigate the fin de siécle world of persecution and skepticism to bring him a "pleasurable harmony of all the senses" (106). In other cases, I found that the combination of queer desire and spirituality works in different ways, but that the pairing always works together to push the boundaries of lateVictorian norms.

Des Grieux's resistance to his love for Teleny (and men in general) illustrates hegemonic social pressure of the time, which forced queer subcultures into secrecy. Before encountering Teleny, we are meant to understand that Des Grieux does not consider himself "homosexual," and indeed discusses the social and religious pressures to resist what the novel repeatedly calls his "nature." But his mystical experiences with the pianist make his same-sex desire undeniable and irresistible. When Des Grieux finally gives in and accepts his love for Teleny, Des Grieux's

\footnotetext{
${ }^{1}$ For more on Antinoüs and his popularity as a figure of homosexual (pederastic) love in the Victorian age, see Sarah Waters' “'The Most Famous Fairy in History': Antinoüs and Homosexual Fantasy."
} 
description of their second kiss (after vowing to love each other exclusively "for ever" "and ever") represents their mystical and physical bond (93). Des Grieux narrates, "a kiss is something more than the first sensual contact of two bodies; it is the breathing forth of two enamored souls" (93). The body/soul duality was a central concern for some Victorians, ${ }^{2}$ and in Teleny the two are united through passionate love.

Teleny and Des Grieux as fictional characters reveal several important things throughout their relationship: the musician represents the type of "sodomite" who accepts himself and his sexual preference, seeing it as natural. Des Grieux stands for questioning men, perhaps in denial about their erotic attractions or socially trained to resist them on moral or cultural grounds. The more experienced Teleny brings Des Grieux into his world of priapic worship and male intimacy, echoing pederastic power balances of experience and innocence. Several themes of the short novel reinforce this Classical echo, not least of which is the reference to Antinoüs cited here-As Linda Dowling has established, Hellenism in the fin de siécle was virtually a code for homosexual love. Similarly, décor and details described throughout the novel (lamps in Teleny's rooms and Briancourt's house, for example) point to Orientalism, which Joseph Allen Boone argues in The Homoerotics of Orientalism is another contemporary indicator of taboo erotics. My claims about their relationship, then, rely on important historicized contexts as well as close readings and the application of modern scholarship.

\footnotetext{
${ }^{2}$ The divide between the physical and spiritual worlds is of central concern to most scholars who explore Victorian spirituality, elaborated upon below. See, for example, Anna Neill's Primitive Minds or Sarah A. Willburn's Possessed Victorians.
} 
Using a New Historicist approach and a queer theoretical platform, I implement close readings to illustrate the important connections between the flexibility of sexual orientation and a variety of spiritual experiences beyond Teleny as I explore the intersections of aberrant erotic relationships and the fascination with mysticism in late Victorian works. The texts I examine reveal that these associations allow queer individuals to experience the validation of their otherwise unsanctioned feelings and actions through the bonds formed by metaphysical powers. Because of the variety of identity options and contexts available, these chapters evaluate a range of similar bonds formed around the two fundamental principles of sexuality and spirituality. I conclude that queer sexual identities and acts, unspeakable and unfixed in the late Victorian years, were supported, represented, and navigated in these works through the use of spiritualism of various kinds. By analyzing the constructive aspects of fluid sexuality and spirituality of the period, I also demonstrate the connection-building potential of a more varied and inclusive formation of identity not based on binary conceptions of sexuality in our modern world.

Clearly, the specific context of this undertaking is pivotal to my understanding of these terms and communities: Teleny was published in 1893, but we can see interest in the qualifying and pathologizing of sexuality somewhat earlier-Foucault identifies this as beginning around 1870 , when "the sodomite had been a temporary aberration; the homosexual was now a species," a quality or lifestyle instead of an act, "a personage, a past, a case history, and a childhood [...] a type of life, [and] a life form" (43). In the latter half of the Victorian era, then, as science and medicine became increasingly interested in all aspects of life, the term "homosexual" came into use with the publication of psychological (Krafft-Ebing's Psychopathia Sexualis, 1886) and medical (Sexual Inversion by Havelock Ellis and J. A. Symonds, 1897) theories of sexuality. Because, as Foucault explains, sexological categories were just emerging, we can understand 
sexuality of the fin de siécle as much more fluid than the current binary allows: men and women with same-sex desires were more free to create loose associations between the way they selfidentified overall (which may have placed more emphasis on class, occupation, or location) and their sexual practices or object preferences.

Scholars often use 1885 as a way to delimit the fin de siècle interest in sexuality because of the passing of the Criminal Law Amendment Act (also known as the the Labouchere Amendment), which made illegal all homosexual acts and speech (public and private) in addition to child abuse and molestation (Dellamora 199). Essentially, the law extended the criminalization of the public act of sodomy to include private acts, thoughts, and feelings, thereby classifying same-sex desires between men as more than a physical action just as Foucault describes: after 1885, a "sodomite" legally became something a man was, rather than sodomy being an act that he did. The Labouchere Amendment also resulted in "enhance[d] police power in working-class neighborhoods" as private sex lives were monitored, which facilitated extortion and blackmail (Dellamora 199). ${ }^{3}$ The new legal concern with the private sexual identity rippled out across contemporary culture, and "sodomite" was often used as a slur, most famously on the card left for Oscar Wilde by the Marquess of Queensberry accusing him of "posing as a Somdomite [sic]" in 1895. But Matt Cook explains why using 1885 as a distinct origin point for such change is problematic: "There was not a wholesale revolution in attitudes or a sudden coherence in perspective in this year, and different views and experiences necessarily co-existed" (4). The 'coexistence' continued into the early twentieth century, when the categories of

\footnotetext{
${ }^{3}$ Cook elaborates, saying, "between men in search of sex, blackmailers, park keepers, the police and watchful bystanders, a circle of vigilance was established" (66).
} 
heterosexual and homosexual currently in use started to solidify. I focus on this period of adjustment and uncertainty, roughly framed by the 1885 amendment and the end of the century, to look at a concentrated period of contexts, influences, queer desires, and spiritual interest.

Like Cook, who points out the coexistence of differences in opinion and experience, many have argued that through the mid-1890s, "sodomites" or others who had queer sexual preferences had wives, children, status, and lifestyles based on heterosexuality, thus illustrating that identity formation was not determined (solely) by sexuality. For example, in his reading of the Wilde trials, Ed Cohen identifies that Wilde "evoked [...] ways that Wilde's aesthetic/personal style directly challenged the dominant interpretations of, among other things, the patriarchal family, class difference, male sexuality, and the politics of writing" (2). Three out of these four things (family, class, and writing) are not inherently tied to erotic object preference at all. ${ }^{4}$ Following pivotal texts by Marcus, Sedgwick, and Dellamora, ${ }^{5}$ I argue that the ideas and ideals surrounding sexuality and identity at the turn of the century were somewhat flexible, while acknowledging the stigma and dangers associated with aberrant desire. Furthermore, identity flexibility allowed portrayals of queer relationships in literature of the time to experiment with links to spiritualism, an area not generally linked to modern sexual identity. The two communities (aberrant sexualities and alternative spiritualities) attracted members despite some

\footnotetext{
${ }^{4}$ This is, of course, excepting the reliance of the family on (heterosexual) biological reproduction: I make this exception because many people with same-sex desires participated in normative marriage and had children, including Wilde.

${ }^{5}$ Namely, Between Women by Sharon Marcus, Between Men by Eve Kosofsky Sedgwick, and Masculine Desire by Richard Dellamora.
} 
stigmatization of practices and a distinct sense of secrecy or mystery. Rather than state or public sanction, supernatural connections between lovers could have authenticated relationships or connections, or mystical expressions could serve to represent erotic encounters that were otherwise unspeakable. I argue that in such a time of flux and stigmatization, literary expressions of the emerging queer community are tied to alternative spiritualities in order to form and negotiate identities and relationships in the texts under review.

Fin de siécle interest in spiritualism and the supernatural is thus a main area of study for the entire project and also requires historicizing. Interest in scientific inquiry and materialism boomed during and after the Industrial Revolution, and Darwin's theory of evolution (which began circulating in the 1860s) put pressure on the preeminence of religious institutions and their ability to describe or define man's place in the world. But Robert F. Geary explains that for Victorians, "the enlightened world of science, despite its contrary claims, offers an incomplete picture of reality: there is another realm — perhaps higher, certainly more encompassing, maybe more terrifying, but not restricted to the prevailing confines of what passes for truth" (105). As science emerged as a dominant field in the nineteenth century, ever refining itself against the unexplainable, many people sensed that something was missing. Although common knowledge of the time claims that the Victorians (in general) went through a mass secularization, more recently the shift away from Christianity has been reframed in scholarship as a shift toward a wide assortment of alternatives. The "other realm" of spiritual alternatives that Geary describes is set apart from our realm by contrast; it is only by looking at what is supernatural that we understand what is meant by the "natural" or, as Geary puts it, the "true." These alternative spiritual experiences and approaches to the supernatural expanded the ways that Victorians thought about god(s), the afterlife, and perhaps most importantly, their own place in the world. 
The sheer variety of positions and practices, like the variety of sexual experiences described by Cook, reveals a "millennial restlessness," which may have led to individuals seeking meaningful connections in new and atypical ways (Oppenheim 65). Spiritualism, then, was a turning-away from dominant Christianity and scientific ideologies in order to seek personal enlightenment or spiritual knowledge. Karl Beckson explains, "in the final two decades of the [nineteenth] century, a reaction to the increasing materialism of the age arose in the widespread interest in the occult—secret knowledge that had ancient and mysterious sourceswhich provided 'Adepts' with confirmation that the cosmos consisted of an eternal order beyond the world of the senses" (320). Groups like the Hermetic Lodge (the London 'chapter') of the Theosophical Society founded by Madame Helen Blavatsky followed ancient Eastern occult teachings and pursued supernatural experiences as evidence of their truth (Beckson 322). "Magicians" demonstrated their connections to the mystical world by channeling spirits and invoking automatic drawing, ${ }^{6}$ levitations, sound-manifestations, table-rapping, ${ }^{7}$ and seances (Beckson 322). ${ }^{8}$ A similar group, The Hermetic Order of the Golden Dawn, explored the mystical Hebrew cabala, which they believed "contain hidden mysteries and magical powers" and drew famous artists and intellectuals like the Rosicrucians, W. B. Yeats, Florence Farr, John Todhunter, Maud Gonne, and even Mrs. Oscar Wilde (Beckson 325). The appeal of spiritualism was powerful: there were over 200 associations, clubs, and societies based on spiritualism, and

\footnotetext{
${ }^{6}$ See Willburn for facsimiles of some of this art.

${ }^{7}$ See Willburn for extensive examples of table-rapping and table dancing, hovering, disembodiment, spirit photography, and more.

${ }^{8}$ I examine the séance scene (S1 E2) in Penny Dreadful at length in Chapter V.
} 
people from all classes were represented (Oppenheim 49). Disagreements among members that splintered such groups, the establishment of multiple chapters, and the wide variety of mystical demonstrations make spiritualism of the fin de siécle heterogenous to an extreme.

As there were many groups and belief systems, relationships with normative Christianity among spiritualists varied; though they (mostly) rejected Christianity and/or science and materialism, there were a wide variety of options and beliefs. Catholics disavowed the practice altogether, but other Christian sects understood the value of spiritualism because it could serve as an ally for Christianity in many ways; Oppenheim says, "The marvels of spiritualism, in short, might be just what was needed for the wasting sickness of the Anglican church" (Oppenheim 81). Belief in life after death, a central tenet of spiritualism, confirmed Christian dogma, and, in fact, spiritualism minimized many of the differences between sects of Christianity because of its simple focus on improving the soul for the afterlife and belief in the inherent equality of all people. However, not all spiritualists embraced such kinship with Christianity; for some, Christianity was precisely what they wished to avoid. Oppenheim says that normative (Anglican) religion was "scarcely secure" in Victorian cultural hegemony and that "refugees from Christianity" were searching for "some incontrovertible reassurance of fundamental cosmic order and purpose" $(1,159,2)$. Anti-Christian spiritualists "abhorred the doctrine of eternal punishment" and since they rejected the concept of inherent sinfulness, they had no need for salvation (Oppenheim 92). A focus on achievable progress in this life meant that anti-Christian spiritualists believed in the power of the individual. Indeed, their spiritualist doctrine held that anyone could achieve salvation as long as they worked to improve themselves.

There were several types of people interested in alternative spiritualities, ranging from true believers, like Christian and anti-Christian spiritualists or members of the Theosophical 
Society and Order of the Golden Dawn, to those who viewed the supernatural as opportunity for scientific inquiry. Members of the famous Society for Psychical Research, or SPR, were such science-oriented researchers, dedicated to investigating the nature of so-called supernatural events. Alison Winter explores in detail one of the earliest practices that was simultaneously science and superstition in her book Mesmerized. As I address in Chapter III, Franz Anton Mesmer created quite a stir with his theory of Animal Magnetism, and although he first proposed its efficacy as a medical treatment at the end of the eighteenth century, Victorians created two waves of renewed popularity for mesmerism, which was renamed hypnotism in the 1840 s, as both a public entertainment phenomenon and an object for serious study by medical professionals and the SPR. From its beginning, mesmerism had undertones of sexual intimacy and generated questions about power, identity, and agency. Mary Elizabeth Leighton explains that these concerns became central for (mostly negative) literary representations of mesmerism. Similar to mesmerism, I explore the ways that possession brings up the same questions. Sarah A. Willburn says that the myriad meanings of possession can create "radical roles, or body uses, [that] often work toward achieving such values as love, equality, beauty, pleasure, natural order, domination, subordination, promiscuity, \& collectivity within a single body" (2). Like mesmerism, then, a touching of minds can mean a touching or merging of bodies and identities.

Another popular movement that combined a spiritual belief with the influence of science was Spiritual Darwinism, which values the evolution of the soul or individual over the evolution of the physical body. Rather than the implied physical touch of mesmerism and possession, one faction of this theory focused on the role of literal sexual intercourse. Willburn explains that the theory pioneered by Lois Waisbrooker "believed that the only way to salvation and spiritual enlightenment is through refined sex acts in which spiritual (rather than material) fluid is 
exchanged" (73). The Waisbrooker theory, then, believed in Dorian Gray's mantra of "cur[ing] the soul by means of the senses, and the senses by means of the soul" (155). Waisbrooker's theory "foregrounds the role that physicality plays in a quest for salvation and enlightenment," thereby bringing together my two central concerns of the sexual and spiritual (Willburn 73). Just as people with same-sex desires had to navigate a culture dominated by heterosexual systems and norms, spiritualists were forced to define and arrange themselves in relation to Christianity and science. Combining the science of Darwinism with spiritual evolution and sex served to legitimize the beliefs of Waisbrooker followers as they faced the dominant ideologies of Christianity, materialism, and chastity. I apply Waisbrooker's theory at more length in Chapters II and III.

Because of the wide variety of beliefs, experiences, and groups that are often combined or conflated in scholarship on spiritualism of the nineteenth century, it has been necessary to narrow my focus to the specific kinds of mystical events under consideration in each chapter. Specifically, I address telepathy and visions, ${ }^{9}$ possession or mesmerism,,${ }^{10}$ and time crossings (possession across time, ${ }^{11}$ community across time, ${ }^{12}$ reincarnation, ${ }^{13}$ etc.). In Chapter IV I also include Paganism: though it is an organized religion, its occult-like rituals and position outside normative Anglican worship make it "mystical" in similar ways to the spiritualism in other

\footnotetext{
${ }^{9}$ Mostly in Chapter I

${ }^{10}$ Chapters II, III, and V

${ }^{11}$ Chapters II, IV, and V

${ }^{12}$ Chapters I and IV

${ }^{13}$ Mostly in Chapter V
} 
chapters. In describing these unexplainable or unnatural occurrences and beliefs, I use the terms supernatural (in the sense of unnatural, above or outside nature) or magical (often triggered by, or linked to, an object or person); similarly, I use the more general term "mystical" for any "transcendent" events "beyond the intellect," along with common colloquial synonyms (OED). ${ }^{14}$ Like other scholars of the field, I use the term "spiritualism" as the blanket term to cover belief or participation in practices outside an organized, normative (Anglican) framework—but beyond Oppenheim's careful consideration of religious-like belief, I also use "spiritualism" to include any sincere belief in the paranormal.

Like the heterogenous "spiritualist" movements and communities described here, there are many terms and classifications that can be applied to sexual identity. The solidification of the homosexual/heterosexual binary shortly after the fin de siécle led to the stagnation of viable sexual identity options for much of the twentieth century. This ideological shift has resulted in some of the unavoidable classifications I make in the following chapters when I describe such falsely-monolithic concepts as the "gay counterpublic" or use anachronistic labels such as "lesbian." As nearly every scholar discussing sexuality of the period points out, these "understandings of sexuality [...] cannot simply be imposed retrospectively," since theories no longer in circulation, such as inversion, would perhaps be more accurate (Cook xiv). ${ }^{15}$ While I do not deny the occasional (and necessary) application of modern conceptions of sexuality onto a

\footnotetext{
${ }^{14}$ For a much longer discussion about the differences between these terms, and others such as "paranormal," see the first chapter of Glen Cavaliero's The Supernatural and English Fiction, "The Joker in the Pack."

${ }^{15}$ See Heike Bauer for an in-depth investigation of Victorian inversion.
} 
period of much less fixed sexual identity, I prefer instead to use the more nebulous term "queer" to describe the variety of individual choices and expressions of desire at the fin de siécle. As George E. Haggerty explains of his own use of "queer," "sexuality needs to be rehistoricized in a way that will undo some of the obfuscation that twentieth-century understandings of sexuality have imposed" (20). I use "queer," then, to attempt to reinstate the variety of experiences and desires beyond binaristic understandings of sexuality. "Queer Theory" also names the specific critical approach I apply to the fin de siécle period. I use a series of applicable types of queer theory to illustrate, as Marcus does in Between Women, that the sexual expressions and experiences which I examine were always already queer in that they were "aberrant" and not restricted to or categorized as only/either homosexual or heterosexual.

The application of queer theory to the selected texts also assists in bridging the differences between male and female same-sex desire by opening the possibility for object preference to a variety of gendered expressions and other traits. Marcus argues for the range and variety of women's relationships, and similarly, Sedgwick's Between Men and Dellamora's Masculine Desire attempt to address the myriad options for male relationships. Sedgwick, however, portrays a "mortal antagonism" between the homosocial and the homosexual, and Dellamora perhaps does not rectify this limitation in his expansion on the topic (Marcus 260). Marcus makes a much more inclusive argument and clarifies that our modern conceptions of relationships as defined by the homo-hetero- binary limit our understanding of late-Victorian same-sex desires. These problems demonstrate the usefulness of queer theory because it resists definition and categories that create "antagonism" and binaries. Though I am, of course, a product of my own time and thus think in terms of such binaries, the following chapters seek to 
undo the primacy of sexological categories by highlighting the other factors (spiritualism in particular) that foster and permit queer couplings or a broader range of erotic expression.

I rely on an intentionally general concept of "queer" throughout most of the following chapters, following Carla Freccero's essential description in Queer / Early / Modern, where she uses the word for its "strategic usefulness as a term" that is "relatively undefinable" (5). As her book does, so too the current project “urge[s] resistance to [queer's] hypostatization, reification into nominal status as designating an entity, an identity, a thing, and allow[s] it to continue its outlaw work as a verb and sometimes an adjective" (5, italics original). Dorian Gray serves as an obvious example: his desires are various, promiscuous, unspoken, and undefinable. In Chapter III I rely on "queer" to describe the Beetle, whose gender and sexuality are liminal and fluid, and in Chapter IV I describe the queer desires of Katherine Bradley and Edith Cooper as the women break gendered norms of sexual attraction and attachment. "Queer," then, becomes a way of looking aslant, looking obliquely, allowing uncertainty to remain—indeed, celebrating and exploring the potential of the unknown. Rather than trying to define the aberrant, I follow Sedgwick's "principal strategy" in Epistemology of the Closet, which is "repeatedly to ask how certain categorizations work, what exactments they are performing and what relations they are creating, rather than what they essentially mean" (27, emphasis original). ${ }^{16}$ Without attempting

\footnotetext{
${ }^{16}$ This method is in direct response to the issue Sedgwick identifies as Axiom 1: "People are different from each other. It is astonishing how few respectable conceptual tools we have for dealing with this self-evident fact. A tiny number of inconceivably coarse axes of categorization have been painstakingly inscribed in current critical and political thought: gender, race, class, nationality, sexual orientation are pretty much the available distinctions" (Epistemology 22).
} 
to strictly define "homosexual" for the fin de siécle, which would be colored by my own ideological standpoint, I look at the relationships, interactions, groups, and spiritual beliefs of people with various desires, allowing them to remain "queer." In addition to the general sense of “queer” Chapters I, II, and V, deploy more specific theories of queer communities, queer time, and queer failure, respectively.

However, the queer is always already defined by its opposition to normative categories of action or identity. As Judith Butler might say, norms are revealed by their transgressionsthereby setting up the aberrant as the "other" category despite its resistance to categorization. This Derridean formulation of the queer clearly indicates its usefulness in literature, as it can serve to reinforce normative behavior by contrast or titillate by presenting new possibilities (as I propose The Beetle does), thereby simultaneously enforcing and questioning dominant social ideologies. As the following chapters developed, it became clear that one genre that closely parallels these queer concerns is the gothic: the twin appeals of repulsion and attraction of the unheimlich or the abject echo the push and pull of normative and aberrant desire. Haggerty's Queer Gothic takes this as its premise, and he says, "gothic fiction offered a testing ground for many unauthorized genders and sexualities [...]. In this sense it offers a historical model of queer theory and politics: transgressive, sexually coded, and resistant to dominant ideology" (2). At the same time, the gothic also provides a "testing ground" for alternative spiritual beliefs and the supernatural. Geary explains, "the ghost story became a vehicle not only for entertainment but also for expression of the uneasy fluctuations of belief on the part of a cognitive minority no longer content with the Christian supernatural yet appalled by the new scientism whose presuppositions they sought to reject or soften" (105). Such spiritual belief was generally categorized across the binary of Christianity or science, as Geary's formulation demonstrates, 
just as sexuality was beginning to fall into the binaristic categories of homosexual and heterosexual. But using the general definition of "queer" established above, we can see that the gothic is doubly queer as it is inherently interested in the liminal and undefinable of both sexuality and spiritualism. Each chapter explores a different version of these factors, connecting queer sexualities to mysterious phenomena such as telepathy, possession, and mesmerism.

The widespread interest in spiritualism and the complex sexual landscape of the fin de siécle overlap in important ways: the intersections of the two historical trends point to particular formulations of late Victorian identity. While scholars, such as those cited above, have investigated homosocial networks, normative sexuality, male homosexuality, lesbianism, sexual inversion, Spiritualist movements, the SPR, Catholic and foreign mysticism, ghost stories, and more, virtually none of them puts the two fields into conversation. Even texts like Haggerty's Queer Gothic and Jack Halberstam's Skin Shows, which demonstrate the role of sexuality in supernatural stories, generally don't highlight the influences or interactions between the two, focusing instead on sexuality alone by exploring genre conventions. Other texts, like Winter's Mesmerized, historicize spiritual practices including their sexual and gendered implications, but of necessity avoid discussing sexuality at length. Interestingly, though, my thesis parallels Winter's: her driving argument is that mesmerism follows the formation of modern scientific process and thought, helping the new field of 'science' define itself by contrast to the fields of phrenology, hypnosis, and more. My thesis, similarly, is that spiritualism of various kinds follows the formation of modern sexual identity markers, helping the emerging categories of sexual desire define themselves through relationships of body and spirit. These two complementary fields, sex and spiritualism, have common underlying motivations for individual 
expressions of navigating the self and other, coping with materialism and exploring dualism, relations to science and the impulse to classify or pathologize. Thus, I argue queer sexualities were expressed through spiritualism or used spiritualism as a mechanism for exploration of possibilities.

As discussed above, aberrant erotic desires were increasingly targeted for persecution and prosecution during the late Victorian period, so one main draw of the spiritual was, perhaps, that spiritualism could be public where queer sex couldn't. As I explore in Chapter 5 especially, spiritualism's widespread popularity meant that seances and table-rapping, automatic writing, mesmerism, and more could be found in parlors and posh drawing rooms all across London. Mediums were invited to entertain guests at parties, and stage-shows demonstrated the powers of hypnotists. Although there was a "gay counterpublic," as I establish in Chapter 1, men with same-sex desires did not have the same ability to travel in public as these spiritualists. ${ }^{17}$ As depicted in literature, at least, these queer men could amplify or express their erotic desires by using the language and experiences of the supernatural.

Two other important resources for public same-sex desire were the vocabularies of Orientalism and Hellenism. While scholars like Joseph Allen Boone and Dowling make clear, indisputable connections between queer erotic desire and Orientalism and Hellenism, respectively, they largely neglect the spiritual aspect I draw into the conversation. For example,

${ }^{17}$ Because of the gendered public/private divide, I necessarily focus on male same-sex desire here; women were generally more free to express homosocial attachment and so were scrutinized less for same-sex erotic desires, but I do explore roughly the same argument about public display in Chapter IV on Michael Field. 
Cook explores the ways that homosexual men could navigate the (public) cityscape of London using Hellenic markers and coded locations, like the Classical statuary collection in the British Museum, in his chapter, "The Hellenic City," and one of the most popular artistic characters of the age was Antinoüs, Hadrian's young lover mentioned above in Teleny. ${ }^{18}$ Similarly, other scholars (such as Oppenheim and Stefano Evangelista) focus on the spiritual potential of importing or reviving alternatives to Christianity, but make no connection to the implied sexual undertones. I use the fields of Orientalism and Hellenism to explore both their contextual sexual implications and the alternative spiritual practices each potentially offered to Victorians.

What I certainly do not mean to argue is that spiritualism was simply a public mask for queer erotic desires at the fin de siècle — not only is this false, but it dramatically oversimplifies the intersections between sexuality and spiritualism that could have as many expressions as individuals. By examining the idea of public, visible circulation, I mean to highlight the fact that being openly gay was essentially not an option for men at the time, and that, in the literature I examine here, spiritualism provided a metaphysical bond for queer couples that could support their relationships despite public disapproval, facilitate the pursuit of queer desires, or even simulate marriage. Certainly not all spiritualists or psychical researchers were homosexual, and not all homosexuals were interested in spiritualism. What I am saying, instead, is that there is a noteworthy body of literature that represents the overlap of the two fields in interesting and telling ways that can help us understand identity and relationships of the time.

\footnotetext{
${ }^{18}$ For more, see Waters' “'The Most Famous Fairy in History’: Antinoüs and Homosexual Fantasy."
} 
I also do not mean to claim that queer relationships need supernatural support in order to be successful or validated; rather, I mean to demonstrate that there are various ways people navigate sexual identity, especially in the face of social prejudice. The addition of spirituality to queer erotic desire ultimately demonstrates the failure of binaristic sexual identity formulations because it illustrates one of the many ways people use different approaches to their sex lives and relationships. There are as many sexual and spiritual experiences as there are individuals, who form identities with various highlighted elements, like the telepathic pianist, immortal prettyboy, shape-shifting beetle, Pagan artists, and demon queen. In each of the following chapters, I examine the ways that spiritualism can represent, inform, or support a character's identity while they explore their queer sexuality.

Chapter I, “Teleny, Telepathy, and the Gay Counterpublic," uses the framework established by Michael Warner's Publics and Counterpublics to examine the possibility of multiple publics coexisting in Victorian London. Warner's now commonly-understood theory of heteronormativity coupled with Nancy Fraser's conceptions of strong publics and weak publics result in what Warner describes as the difference between a dominant public and a subordinate public (a "counterpublic"), most often defined in direct relation to each other. Warner's dominant, heteronormative public serves as a backdrop for nearly every counterpublic, and counterpublics are defined, at least in part, by the ways they oppose or subvert heteronormativity. The more colloquial term "subculture" is comparable in meaning, and these community groups do imply a homogenized population of members, but I use the terms more as a loose association between individuals who have at least one pivotal aspect in common, and, as I describe in the chapter, have established procedures for initiation and membership activity. 
Tensions with the dominant public are often related to the individuals' subaltern status or participation in a specifically taboo subculture like homosexuality in the 1890 s. Warner emphasizes the counterpublic's ability to create "a horizon of opinion and exchange" because counterpublics are not limited by hegemony (57); instead, they create new norms based on their members' needs and desires. One of Warner's focal points is the counterpublic created by the gay community, which others (such as Matt Cook on the Victorians and Samuel R. Delaney on recent trends) have written about at length. Because the community is established based on selfselected members using male homosexuality as the core commonality, I use the term "gay" as an adjective repeatedly in the chapter despite its being anachronistic.

In Teleny, the gay counterpublic intersects and interacts with mystical events that indicate an extensive and established community of spiritualists as well. This combination, then, perfectly encapsulates the potential of the overlap of queer sexuality and alternative spirituality. The opening scene quoted above illustrates one aspect of the supernatural in the novel: Teleny's music causes Des Grieux to see elaborate visions while becoming inexplicably sexually aroused. Meanwhile, the presence of Des Grieux among the thousands of attendees impacts Teleny greatly: after the performance, he says backstage, "I felt that somebody was listening to me" (11); he means a "sympathetic listener," implying intimate connection despite the crowd (11). I use scenes of intersection such as these to discuss the potential impacts of the supernatural on gay identity and relationship formation, and argue that the unexplainable elements that bring Des Grieux and Teleny together are what help validate their relationship despite Des Grieux's initial hesitation to identify as gay.

The metaphysical connection between Teleny and Des Grieux allows them to develop their queer erotic relationship into one that is not only acceptable, but is also more meaningful 
than a merely physical relationship. Close readings of the supernatural and erotic scenes reveal a fervently religious aspect to their physical encounters, establishing the important role of spirituality in sex. Teleny's mystical powers are established through descriptions of his spelllike incantations, mesmerizing eyes, and “electric” touch. Des Grieux's mystical vision repeatedly connects him to Teleny, especially in moments of arousal. When the two men come together and come together, their ecstasy unites "the flesh, the blood, the brain, and that undefined subtler part of [their] being" (93). Ultimately Des Grieux and Teleny's relationship ends in tragedy when Des Grieux finds Teleny having sex with his mother. I argue that Teleny's ensuing suicide indicates the anxieties of the authors and the gay community about hegemonic condemnation of gay lifestyles, "passing" as straight, and performing culturally-compulsory heterosexual acts without love, anxieties exacerbated by the repression or betrayal of spiritual connection. However, the end of their romance also reveals a very normal anxiety about fidelity which validates familiar emotions despite difference in sexual object, and the bold portrayal of same-sex love throughout the novel provides hope and sympathy for a queer audience, creating a community of readers as well.

Teleny is often attributed in part to Oscar Wilde, and The Picture of Dorian Gray is a fitting choice for chapter two. It is readily apparent that Dorian participates in and contributes to the construction of stereotypical markers for the gay counterpublic such as interest in decadence, art, fashion, and youth as much as Wilde himself does. While some (like Sedgwick) contend that Dorian is merely a part of an intensely homosocial environment, I agree with others (like Dellamora) who argue it is too difficult to clearly separate the homosocial from the homosexual, and, by extension, that Dorian's 'influence' on his peers may have included same-sex erotic encounters. Following Dirk Schulz's lead, instead of attempting to define Dorian's sexuality, I 
allow him to remain queer in order to analyze the impact of the picture and its magic on Dorian's identity-building and sexual encounters. Dorian's obsessions with collecting various commodities and experiences, in fact, support the contemporary uncertainty surrounding sexual identity and queer theory's interest in multiplicity. But I assert that Dorian's queer sexual and social choices would not have been likely without the magic of the portrait. Thus, the mystical element allows the queer sexuality to emerge and, in fact, encourages increasingly errant behavior in Dorian.

Because his picture suffers disfigurement instead of his body, Dorian feels free to experiment with queer desires. His body is suspended in time, unchanged by sin or age-but this connection to the portrait also means his soul is divided from his body. These two themes become important areas as I investigate the specific ways that the magic of the portrait and Dorian's queer desires work together: Dorian experiences “queer time” and possession or transferal of the soul/self. "Queer time," the theory of resisting "chrononormativity" by living in a perpetual present and interrupting futurity, was proposed by Jack Halberstam and further developed by Elizabeth Freeman (Freeman xxii). Dorian's unaging body and disinterest in forward-looking concerns such as taking care of his reputation and creating a family demonstrate queer time by preventing his growth, development, and attachment to normative temporal progression. Moreover, repetition of specific tropes and themes in the novel allow the reader to experience a similar temporal stagnation by creating a circular experience that keeps the reader in a perpetual present. "Time-slip," a literary trope proposed by Kingsley Amis et. al., explains such queer slippage and links queer time to supernatural time phenomena.

While queer time is linked to the magical suspension of aging in the portrait, the portrait enables such time-slippage specifically by possessing Dorian's soul. Thus, the second 
specifically supernatural element in The Picture of Dorian Gray is the curious transferal of Dorian's soul into the portrait, leaving his body uninhabited and open to possession by others. I explore how Wilde's frequent use of "influence" and fascination could indicate more a form of spiritual possession through Dorian, Lord Henry, and Basil, and the language they employ to describe their relationships. The variety of identities embodied by Dorian and his portrait further implicate his queer nature by continually emphasizing multiplicity and variety. But as with Teleny, Dorian's tragic end reveals certain anxieties tied to his lifestyle and the portrait's power. The destruction of the portrait (and Dorian) reveals a fear of being exposed as queer and an intense struggle with morality and guilt, a major concern of alternative spiritual communities. This tension between acting on what feels pleasurable or natural and what is socially or culturally acceptable illuminates the parallels between aberrant sexualities and mysticism, and it highlights the negative impact that society has on morality and individual expression which otherwise may hold positive potential. But perhaps more remarkable is that by destroying his portrait, Dorian also attempts to reassert himself in normative time and re-claim his own soul. By trying to fix his own queer identity in time and place, he undoes the very things that make him who he is, and he dies. The conclusion of Dorian Gray, then, cautions against undoing the life-giving potential of queerness.

Chapter III on Richard Marsh's The Beetle also explores the power of queer desire and possession, in this case projected onto a framework of Orientalism and rooted directly in historicized understandings of mesmerism. Late Victorian Orientalism was a source of much interest because of its potentially occult aspects, and, as Joseph Allen Boone has clearly shown, was a field that created space for experimental sexual practices as well. I argue that the use of Orientalism in The Beetle is a way of portraying the two communities of alternative sexuality 
and spirituality simultaneously, and argue that the unknown Beetle figure reveals the two subcultures by representing their unification in her body: she is the shape-shifting figure of ancient cult worship who takes part in mystical rituals, has fluid gender expressions, and has unfixed sexual object preferences. This combination of features serves to cement the affiliation of alternative queer and spiritual communities through the Beetle's participation in both.

More specifically, Marsh deploys mesmerism throughout the novel to explore the boundaries between the self and other, questions of control and agency, and dominant and submissive power structures. My chapter explores the historical understandings of mesmerism (renamed hypnotism in the 1840s) and its sexual undertones to conclude that Marsh uses the practice as a vocabulary for queer erotic desires. Even at its inception, mesmerism involved a suspicious amount of intimacy through touching, and practitioners were often suspected of taking sexual advantage of their subjects. ${ }^{19}$ The mingling of minds and the transgressions of gender, nationality, and power that the Beetle also represents make the eroticism of hypnosis queer in that she is undefinable. Thus, the Beetle combines the queer erotic subtexts of Orientalism and mesmerism with her own touching, control, and sexual abuse to present the reader with the perfect gothic monster. ${ }^{20}$ This gothic monster is meant, of course, to both

${ }^{19}$ In Teleny, for example, a doctor recounts how he was once called to massage feeling back into a woman's legs_-during treatment, she passionately cries, "But I think you are mesmerizing me, doctor!" in order to convey her willingness to be seduced by him (129).

${ }^{20}$ Halberstam says, "the monster functions as a monster [...] when it is able to condense as many fear-producing traits as possible into one body" and adds, "The Oriental" figure serves as a “generalized code of fear" (Skin Shows 21, 14). 
fascinate and repel the reader; the Beetle embodies tantalizing gender fluidity and sexual power, but wields them in terrifying ways in order to illustrate their dangers. Like Wilde and others portrayed queer relationships, actions, and communities, most Victorian narratives submit to hegemonic pressure to end in a way that ultimately condemns and stigmatizes both same-sex desire and mysticism. I demonstrate the ways that The Beetle follows this normative trend by killing the evil abhuman representative of mesmeric ability and transgressive erotics. However, I also consider at length the ways the novel allows queer desire to survive and continue to circulate in London.

While Marsh uses the coded languages of Orientalism and Mesmerism to explore queer desire, Katherine Bradley and Edith Cooper use Hellenism. Chapter IV explores how Michael Field (the pen-name of the aunt and niece) deploys Classical religion and figures to support their loving relationship. The women had "a sensual, pagan, and erotic mode of being" which combined same-sex desire and alternative spirituality to fortify their unique partnership (Thain, Vadillo 27). The pagan aspect of their lives was integral to their understanding of love, identity, and art; they repeatedly use Classical imagery and modes in their writing, reimagine dramas from earlier periods and channel Sappho. Their volume of poetry from 1889, Long Ago, which completes Sapphic fragments, is the featured work in the chapter, and I argue that 'the Michaels' use Sappho as a lesbian-poet-mother touchstone for exploring their own textual and sexual connections. Supported by Dowling's pivotal work on Hellenism, it becomes clear that Field's interest in Sappho and other Classical figures (such as Tiresias) is part of a larger trend that used Hellenism as a code for homoerotic attraction and as an escape from the restrictive morality of the fin de siécle. 
With its twin subtexts of pagan religion and same-sex desire, Hellenism is an important area for study of Field scholars, but my chapter also explores the importance of their artistic collaboration to their life-long writing partnership. As Wayne Koestenbaum and Jill Ehnenn have argued, collaboration is akin to sexual connection; the mingling of minds is like the touching of bodies, ${ }^{21}$ and collaboration is thus both sexually suspect and especially productive. Putting these things into conversation, I coin the term "aesthetic marriage" to describe the indissoluble bond the women form, which is sexual, intellectual, and spiritual. This bond, symbolized by their unity under the masculine pen-name Michael Field, is expressed in the language of pagan celebration and longing and lived in maenadic worship and the fiercely independent identities that the two women built around their fluid gender and sexuality. Additionally, Sappho's role in Long Ago helps describe and define aesthetic marriage: her sexuality is fluid, her worship is pagan, and her identity centers on her art. Field de-crypts Sappho to use her voice, uniting across time to collaborate with a lesbian predecessor to create pagan art. Their artistic collaboration thus becomes a central uniting feature of their sexual and spiritual union.

To close the dissertation, I use Showtime's Penny Dreadful (2014-16) as a case-study in Chapter V to explore the ways that modern society conceives of identity and how the overlap of queer and supernatural identity markers compare to our Victorian predecessors. Set in 1891, the show is a pastiche of the titular Victorian press phenomenon and includes many characters familiar to readers of Victorian fiction, including Dorian Gray. I examine Dorian's

${ }^{21}$ This is similar to the argument about mesmerism I discuss in Chapter III: dissolving mental barriers implies the sexual penetration of bodies as well as minds. 
characterization in much the same way as the original in Chapter II, concluding that the debauchery Dorian enjoys serves to create visibility for the modern audience and to encourage acceptance. Another main character, Vanessa Ives, is not based on a single fictional Victorian character, but rather embodies a combination of popular contemporary imaginings of mesmerism, divination, occult magic, and possession. In the cases of both Dorian and Vanessa, unique and supernatural qualities are brought out by, result in, or are otherwise significantly related to erotic episodes, many of which are queer. Additionally, the dark, traditionally gothic nature of the show serves to demonstrate the lingering fear and stigma surrounding alternative sexualities and spiritualities, while their very portrayal on television reveals increasing acceptance of their public appearance. Our changing perceptions of sexuality and acceptance over time bring in unique challenges studied by Neo-Victorian scholars. Similar to John Kucich and Dianne F. Sadoff, I argue that the resurrected Victorian/gothic/horror/penny dreadful milieu gives modern viewers the opportunity to re-evaluate our own beliefs from the safe distance of more than a century.

Using this Neo-Victorian contextual and ideological backdrop, my main consideration is how sexuality and the supernatural are intrinsically linked for Vanessa: her first sexual encounter (aberrant in partner choice, though heterosexual) is portrayed in a flashback, and triggers what we know to be a life-long struggle against demonic forces that continually try to possess her soul. I examine specific episodes in Season 1 to explore the other times Vanessa is seen having intercourse, and immediately before or after each episode, she experiences another supernatural attack. The show is heavy-handed in linking sex to Vanessa's paranormal abilities, seeming to argue that women who have transgressive sex will inevitably suffer for their sins. I argue, however, that the sex ultimately falls somewhat beside the point: the viewer is encouraged to 
relate to Vanessa as the protagonist, she is strong-willed, fiercely independent, and uses her demonic powers for good (most of the time). I conclude that although sex is certainly linked to Vanessa's supernatural abilities, the show's focus is on her struggle in the war between good and evil, demonstrating that sexuality does not necessarily have to hold the primacy that modern ideologies give it. This de-emphasizing of her heterosexuality allows Vanessa to form her own identity, which is the central concern of the show.

In Season 3, however, Vanessa rejects the responsibility to define herself and briefly succumbs to her dark side before she is killed by Ethan Chandler. I use Halberstam's theory of "queer failure" to describe Vanessa's death and decision to opt out of the struggle for her soul. Halberstam proposes a radical rejection of normative, forward-looking life by discussing the potential of choosing failure instead. Rather than continuing the exhausting struggle between good and evil—that is, rather than struggling with heteronormative ideas of morality, femininity, and family to be herself: powerful, independent, and supernatural—Vanessa opts to die. Halberstam says, "failure allows us to escape the punishing norms that discipline behavior and manage human development," like moral and sexual conformity ( $Q A o F 3)$. Failure, then, provides us with a radical way of rejecting established systems of choice. Vanessa's death creates "a shadow archive of resistance, one that does not speak in the language of action and momentum but instead articulates itself in terms of evacuation, refusal, passivity, unbecoming, unbeing” (Halberstam QAoF 129). As Halberstam's theory makes clear, this “archive of resistance" is possible — even necessary—in the real world of Penny Dreadful's audience as a social and political mode. Similarly, the visibility of Dorian's alternative sexuality in the show may encourage progress toward seeing the potential of queer sexualities and spiritualities, and perhaps will enable us to break the limitations of the homo- /hetero- binary and embrace variety 
in the twenty-first century. These admittedly optimistic readings of the show demonstrate its importance in the dissertation project, as it concludes the work by bringing the Victorian texts of earlier chapters into conversation with actionable modern social and political projects of navigating heteronormativity using sexuality and spirituality. 


\section{CHAPTER 1: TELENY, TELEPATHY, AND THE GAY COUNTERPUBLIC}

There are other novels and short stories circulating at the fin de siècle with gay or queer themes, erotic scenes, and mysticism, but Teleny stands alone in its graphic portrayal and heightened treatment of these topics as intrinsically linked. The combination of the gay erotic and the mystical is central; the fusion of the two reveals identity-building on an individual level and unites two queer spheres (the gay community and the community dedicated to alternative spiritual belief) to create a strong bond between individuals and members of both groups. The supernatural elements of Teleny reinforce and support the central gay relationship and the identities of the two men at the center of the story. The unexplainable phenomena that bring Des Grieux and Teleny together are what help validate their relationship despite Des Grieux's initial hesitation to identify as gay. Their metaphysical connection allows them to develop their queer erotic relationship into one that is not only acceptable, but is more meaningful than a merely physical (or state-sanctioned) relationship.

The contemporary context of fin de siècle London defines many of the communities Teleny addresses and navigates. ${ }^{1}$ Written by a group of anonymous authors, Teleny was first published as set in Paris, but it is evident that the locations described are in London, and the publisher, Leonard Smithers, admitted that he had changed the setting only to appease British readers' sensibilities (Hyde, History 143). While other books, such as Sins of the Cities of the Plain, and events, like the Cleveland Street Scandal made London citizens widely aware of the gay community's presence, queer individuals of various sorts were still ostracized, scorned, and even occasionally prosecuted. This atmosphere, largely created by the Criminal Law

\footnotetext{
${ }^{1}$ For a more on these contexts, see the Introduction.
} 
Amendment Act (also known as the Labouchere Amendment) of 1885 and the increasingly pathological treatment of sexuality, features in Teleny in many ways which will be explored shortly.

Meanwhile, the supernatural bond between lovers was a well-established literary trope as well: many Victorians used unexplainable connections and events to add veracity or interest to relationships, and many ghost stories are subtly erotic. Vampire novels and stories, and ghost stories by such authors as Vernon Lee and Sheridan Le Fanu include the element of paranormal romance in their pairing of living and dead partners and details like calling a vampire's bite a "kiss." Even canonical authors like Charlotte and Emily Brontë, who have their lovers connected across time and distance, Christina Rossetti, who writes of Goblins and death, Swinburne, who links love to ancient gods and powers, and Wilde, who will be discussed at greater length in the next chapter, all address the role of the supernatural, metaphysical, or paranormal in love. ${ }^{2}$ However, Teleny stands out as a novel that fixes its central axis on the intersection of the mystical and erotic rather than using the trope as merely one event among many or as backstory to another narrative.

\section{The Gay Counterpublic}

Michael Warner's theory of counterpublics informs my study of the gay community in Teleny. Beginning with Habermasian conceptions of public and private spheres and Nancy

\footnotetext{
${ }^{2}$ Specifically, consider Jane Eyre, Wuthering Heights, “Goblin Market," Swinburne's Poems and Ballads and Wilde's short stories. Chapter II focuses on Wilde's The Picture of Dorian Gray.
} 
Fraser's conceptions of strong publics and weak publics, Warner's Publics and Counterpublics examines the possibility of multiple publics coexisting. Warner describes the difference between a dominant public, which he calls heteronormativity, and subordinate publics or counterpublics, often defined in relation to each other and the dominant public. These counterpublics challenge the norms and are "defined by their tension with a larger public" (Warner 56). The tensions with the dominant public are often related to the individuals' subaltern status or participation in a subculture. Warner emphasizes the counterpublic's ability to create "a horizon of opinion and exchange" because counterpublics are not limited by hegemony (57); instead, they create new norms based on their members' needs.

Teleny serves as an especially good example of Warner's publics and counterpublics interacting, as the novel's gay and mystical communities overlap and work together to challenge the dominant public of Victorian society. In Teleny, the primary counterpublic is the gay underworld of London, a queer space in both senses of the word, liminal and yet quite active and encompassing many members. The other counterpublic in Teleny is the widespread belief in mysticism. Although not portrayed as an organized group in the novel, the mystical movement at the end of the nineteenth century was well-known; this counterpublic subverts the dominant Christian public. Combining these two groups, Teleny helps create a negative definition of the dominant public - what heteronormative Christianity is not is accepting of other sexualities or religions. Because these two identities fall outside (or counter to) the dominant public, they become counterpublics. Authoritative social rules are made by the agreements of the members of a community, which are often defined by their negation: transgressions reveal what is being transgressed. The dominant public determines as a group what is "normal" or acceptable in society at large, thus drawing the line which counterpublic crosses (though individual 
counterpublics may also have internal socially-agreed upon norms and modes). A counterpublic group is made up of those who push the limits of identity as defined by the dominant public and are thereby rejected by hegemony.

In Teleny, we see the struggles of gay men to live within the bounds of society's heteronormative constraints while also confronting their own inner desire to belong to a public. The gay underworld of London, as it constitutes a counterpublic, highlights the dominant public as heterosexual. We also see individuals immersed in a Christian society experiencing undeniably non-Christian phenomena and even anti-Christian rhetoric. The counterpublic of mysticism, likewise, helps define Christianity. ${ }^{3}$ In each case, resisting the norms of society to form an individual self and to address private needs highlights the greater connections that are being created or tested. The two resulting counterpublics in Teleny, united by homosexuality and mysticism respectively, each individually puts pressure on the dominant public, and also work jointly to challenge heteronormativity. The most obvious space of overlap is in the two primary characters, Teleny and Des Grieux, who participate in both counterpublics.

Although the focus of Teleny is clearly the homosexual London underground, there are passages that directly challenge the dominant public of Victorian society. Warner says, "dominant publics are by definition those that can take their discourse pragmatics and their lifeworlds for granted" (122). The novel examines these default norms from an outsider's

\footnotetext{
${ }^{3}$ Certainly it must be noted that "Christian Mysticism" is also widespread and could constitute its own counterpublic/subculture. The mysticism in Teleny generally makes no mention of Christian influences, and indeed, Des Grieux often criticizes the dominant theological stance on homosexuality, so I will not be addressing Christian Mysticism in any detail.
} 
perspective and is critical of the general public. Society's ideals are often treated with derision in the novel: after Teleny sulkily imagines that his lover might eventually grow tired of him and want to marry a woman and start a family, Des Grieux says, “"A family!' I burst out laughing. 'Is that encumbrance so very necessary to a man's happiness?'” (143). Des Grieux is similarly critical of normative religious reactions to sodomy, and he frequently criticizes social norms based on Christianity as hypocritical and favors "nature" or his "constitution" as justification for his sexual preference.

As established by Des Grieux's constant sarcastic and negative portrayals of the dominant public, the reader is encouraged to sympathize with the plight of the homosexual in Victorian society. ${ }^{4}$ Des Grieux appeals to a reader's logic and empathy by emphasizing that he tried to resist his homoerotic urges throughout the novel; for example, before succumbing to Teleny's charms, he says things like "I had been inculcated with all kinds of wrong ideas, so when I understood what my natural feelings for Teleny were, I was staggered, horrified; and filled with dismay, I resolved to stifle them" (47). It is important to note the subtle use of the word "natural" in this passage especially_the novel repeatedly insists that homosexuality is no less "natural" than heterosexuality. Des Grieux's resistance, however, also reveals the difficulty of acknowledging - much less acting according to - his gay nature. The social stigma assigned to sodomy and its (often stereotyped) associated lifestyle meant that men in Des Grieux's position were socially conditioned to abhor their "natural" feelings.

\footnotetext{
${ }^{4}$ Warner says, "publics act historically according to the temporality of their circulation," emphasizing that counterpublics are necessarily rooted in their individual contexts (96).
} 
Personal guilt and internal struggle were not the only negative consequences in Victorian England: as Des Grieux experiences firsthand, blackmail was an ever-present reality for gay men after passage of the Labouchere Amendment. Being "branded" (to use the graphically violent word with which Briancourt threatens Des Grieux) a sodomite in the eyes of society was a serious danger that could lead to prosecution and even imprisonment. Des Grieux describes the receipt of the blackmail note very clearly, calling it a "horrible, infamous, anonymous threat, in all its crude harshness" (110). Blackmail was especially dangerous for the upper classes, whose entire social identity often relied on reputation. The Labouchere Amendment thus helped solidify binary sexual identity by linking sexual practice with the social interactions or standing of "sodomites" and left gay individuals vulnerable to blackmail and other attacks. ${ }^{5}$ Teleny resists this movement by portraying the humanity and happiness of gay men within their underground community, and simultaneously critiques the social constructs that link personal identity to sexuality by pointing out their hypocrisy.

While adult sodomy was a punishable crime, especially after the Labouchere Amendment passed, same-sex encounters and experimentation were the well-known but commonly hushedup norm among adolescents at boarding schools and in the military. ${ }^{6}$ Accounts of sodomy

\footnotetext{
${ }^{5}$ Indeed, communications like blackmail constitute part of Warner's definition of a counterpublic, which involves "both personal and impersonal" speech (76). The blackmail note is personal (directed at Des Grieux) and impersonal (representative of blackmail that could happen to any homosexual).

${ }^{6}$ For more on historical accounts of school-age and military sodomy, see Kaplan, "Part Two: Love Stories.” Boys were often punished and their sexual activities stopped upon discovery, but
} 
among young men were so common that many saw the practice as a sort of right-of-passage, necessary for character- or male-bond- building exercise, or even as a precursor or practice for sex with women. Des Grieux and other gay men were especially critical of this kind of hypocrisy: turning a blind eye to childish indiscretions while blaming the grown man for merely continuing a common practice seems irrational. Des Grieux's mother is well aware of the practices at public schools, and he narrates, "I had never been put as a boarder into any school, for she knew that such places of education are — as a rule — only hot-beds of vice" (34). So, in Teleny, the authors present Des Grieux as largely innocent of adolescent experimentation: this portrayal perhaps works to fetishize his sexual inexperience as novelty or to emphasize his innocence in the sense that he was a virtuous man, despite his same-sex desire. This second reason would also reinforce the idea that sexual preference is not at the center of identitybuilding; by the time he embraces his sexuality, Des Grieux sees himself as honorable and true to his own nature — things any person might strive for — rather than the socially-projected sinful degeneracy associated with sodomites, who likely made up the entire original reading audience. Thus, he disassociates his core identity and values from his object of sexual preference.

Teleny, though, is undeniably about gay men as gay men. While it puts pressure on forming an identity solely around sexual preference, it emphasizes the positive aspects or potential of allowing same-sex desire to influence self-formed identity and to create a community or counterpublic. Des Grieux's mother's concern about his exposure to boyhood experimentation in sodomy hints at the existence of such a community, as does his first

they were not permanently socially discredited or even severely chastised: rather, the situation was usually covered up as quickly as possible to avoid scandal. 
appearance in the green room during the intermission of a concert where he first sees Teleny. This scene includes a mostly empty room, containing only “a few dandies," Briancourt, and Teleny (9). Briancourt is described for the first time in a short passage that highlights his "conspicuous" way of dressing and his "ogling," not just of women, but of "everybody" (9). In combination with the "dandies" grouped around him, we can deduce that the small group gathered in the green room is a group of gay men, a hint of a larger community. ${ }^{7}$ Teleny stands in their midst, and as Briancourt introduces the two men, Des Grieux gets an erection. Teleny is part of the gay counterpublic by association, and their first handshake acts to let Des Grieux into the secret that the community exists.

Des Grieux resists full membership in the community, though, and denies his same-sex desire for Teleny for a long time. As mentioned above, this hesitation is largely due to his social conditioning, and Des Grieux struggles to do what is "right" before realizing what is "natural" cannot be wrong. When Des Grieux submits to his feelings for Teleny and they have a rapturous first night together, the auditor suggests he might feel some (socially-conditioned) shame, and he replies, "Why? Had I committed a crime against nature when my own nature found peace and happiness thereby?" (107). Thus justified to himself, his listener, and the reader, he embraces his love for the pianist as an individual and reshapes his self-defined conception of his identity; we can see that in Des Grieux's experience, his self-recognition and identification with a label (like "sodomite") acts to reclaim the label from the stigma of the dominant public. Thus equipped

\footnotetext{
${ }^{7}$ Briancourt's small group, chatting behind stage, emphasizes Warner's first parameter for counterpublics, "a public is self-organized," as designating "a space of discourse organized by nothing other than discourse itself" (67).
} 
with “peace and happiness," Teleny encourages Des Grieux to join the community of others who have same-sex desires.

Each of the participants in the publics described in Teleny and in the London homosexual underground self-selected as members of those publics. Warner describes this 'essential circularity' as not just a subscription-like membership, where one signs up and promptly forgets all about the group $(67,69)$. Instead, active participation is required for a public to form (Warner 69). Opting in is much more meaningful than being a part of a group by default or by chance. An initiation ceremony is a clear way of presenting a new member to a group while ensuring that the new member is conscious of their act of joining. Des Grieux's initiation occurs at Briancourt's “symposium,” an exclusive gathering of men (though some are dressed as ladies) for a night of debauchery. He is initially hidden behind a screen, and then masked: obvious attempts at remaining a "stranger" to other members of the counterpublic. ${ }^{8}$ Other guests try to guess who he is, and finally one guesses correctly and his mask is removed: the revelation of his identity is greeted by offers of kisses and groping hands. While he observes the assembled men, he is not an active member but an outsider; it is not until his face is revealed and he is acknowledged by the others that he is fully admitted into their community. Such a ceremony, complete with naming and physical confirmation of acceptance, formalizes membership in the gay counterpublic.

Des Grieux's masked entry, the guessing game played about his identity, his naming, and finally his acceptance at Briancourt's party create a ceremony that is part of the pageantry

\footnotetext{
${ }^{8}$ This detail emphasizes Warner's second parameter for counterpublics, that (counter)publics are “a relation among strangers" (74).
} 
associated with the gay community. Even within the dominant public, the gay man as a Foucauldian "species" stereotypically performed a more flamboyant presence than his straight counterpart. ${ }^{9}$ Richard Dellamora theorizes that this particular expression of identity is a direct result of an imbalance of work and leisure, where too much leisure tips the scales toward effeminacy. The contemporary term "invert" thus might indicate a man with same-sex desire or a man whose gender performance was too feminine. The two became tied together for gay men and thus the stereotypical gay dandy was formed. ${ }^{10}$ The aesthetic concerns of the dandy and his associated pageantry became symbols of the gay man, though his preference for sodomy - the factor that defined his sexuality — was often the most closely-kept secret imaginable because of the threats of blackmail and social scorn addressed above. This combination of pageantry and secrecy meant that the counterpublic found underground venues for their most visibly flamboyant expressions, like the party at Briancourt's.

Briancourt's "symposium" further illustrates, through the gratuitous displays of group sex, that the emphasis in homosexual society is the collective, not the individual: "its emphasis on multiplicity and exchange seeks to subvert the construction of the 'homosexual' as singular and identifiable and to replace the certitudes of individuation with the pleasures of anonymity and collectivity" (Gray, Keep 201). Some members of the group are familiar faces, some are

\footnotetext{
${ }^{9}$ From his first appearance in the text, for example, Briancourt's performed identity is an indication of his membership in the gay counterpublic; Warner says that there is "a performative dimension of public discourse" that attracts the knowing attention of other members (114).

${ }^{10}$ For a much more in depth discussion of masculinity and inversion, see Heike Bauer's English Literary Sexology: Translations of Inversion, 1860-1930 (2009).
} 
perfect strangers, some are surprising reveals, but all participate on a similar level and are part of the whole. The homosexual counterpublic, made up of self-selected individuals, is heterogeneous and made up of relative strangers made into a unified group of equals. In its representation of Teleny and Des Grieux and their milieu, the novel creates a parallel to all homosexual relationships and a microcosm of the greater homosexual community of London. Members of that community at large would be tied together by their commonalities as defined by the larger group of society and their interactions with each other and with outsiders. Moreover, the anonymous group of (most likely gay) authors who wrote Teleny undoubtedly formed such a community, and the original (most likely gay) readers of the book reflects the larger gay counterpublic as well. Such bonds of community belonging, as in the novel, are defined in contrast to hegemony, but they carve out their own space and create their own counterpublic to encompass others with shared interests.

One way of defining a counterpublic or creating safe spaces for openly sharing same-sex interest is by creating socially-agreed-upon physical meeting places that allow for expressions not permitted within the dominant social sphere. Briancourt's house serves as the most obvious example, as it is a place of gathering and active sexual engagement. Matt Cook, who discusses gay spaces at length, says that city bachelor homes provided "rooms and habits of life that were separate from, and not to be questioned by, his household and family" - that they provided relative freedom and privacy for same-sex erotic acts (31). We are to understand that Briancourt is unmarried and his father is, strangely, present at his party, so his home is less an escape from his normative family and more a private oasis of same-sex erotic activity, safe from the prying eyes of the public. Like other private rooms kept by gay men (Cook 31), Briancourt's hall is described as lavish and dark with closed, heavy curtains and artificial light, heavily perfumed; 
Des Grieux says, "it seemed to me as if I were in some rank jungle," and "I had been transported into the magic realms of fairy-land" $(123,121)$. As Cook explains, "fresh air and light, the conduits on Victorian health and vitality, were absent, and the public gaze was shut out" (57). These gay spaces were thus set apart from the dominant public in almost every way.

The green room, backstage at Teleny's concerts as discussed above, also hints at a type of safe gay space. Cook says, "the theatre was frequently represented as a liberal and radical arena, where sexual hypocrisy might be challenged and difference affirmed" (29). Teleny's profession as a musician serves to highlight the space where he circulates within the gay community, and Des Grieux's presence backstage at the theater/music hall hints at his eventual initiation. Cook says that public gay spaces "figure homosexuality as both outside but also dangerously within mainstream urban culture," the physical spaces helping the counterpublic to overlap with the dominant public (55).

Beyond the theater, there were also outdoor spaces that served as meeting places for gay men: for example, Des Grieux, following the familiar figures of Teleny and Briancourt home one evening, is walking through the park and is propositioned by strangers who are unquestionably part of the homosexual counterpublic. Although this occurs before Des Grieux's initiation, he recognizes the group that the men belong to: "some signs are so evidently clear and full of meaning that no initiation is needed to understand them" (85, emphasis mine). He recognizes a kind of kindred nature in the male prostitutes and says that he is not appalled, but fascinated by their approaches; he says "the scene was so entirely new that I must say it rather interested me" 
(86). ${ }^{11}$ His narrative musing indicates that Des Grieux recognizes strangers as members of the same counterpublic, despite their strangeness, in part because of their location. Matt Cook names Piccadilly Circus, Hyde Park, the West End, public toilets, Turkish Baths, bookshops around SoHo, and more as important sites for the circulation of alternative sexual encounters. Spaces like the park in this scene were "places of confluence rather than separation," an important distinction to a group so stigmatized by the larger cultural authorities, and they fostered "a shared circuit [of] subcultural knowledge" (Cook 45, 36).

Space, then, is necessarily part of creating the community portrayed in Teleny despite its transferal from London to Paris when published. Cook argues that "the city appeared to be a vital element in the genesis of sexual abnormality" (78), even beyond London to other major cities, creating an "urban circuit of homosexuality" (86). The importance of cruising and having public places for gay presence like parks, theaters, hotels, streets, markets, etc. allowed for a "sense of permanence and belonging" in gay culture, and these locations "indicated a series of places in which prevailing conventions and ideologies might be exploited, adapted or resisted" (Cook 22). Samuel R. Delaney documents similar spaces and their uses in Times Square Red, Times Square Blue, arguing for the continued importance of such places for the gay community even 100 years later in New York City. He says that the social functions of safe spaces for gay erotic activity, like movie theaters, drew an "incredibly heterogeneous" group whose interactions were full of "charm, sociality, and warmth" $(15,25)$. The identities, needs, histories, lifestyles, etc. of the men seeking out safe gay spaces were various, emphasizing the multiplicity of

\footnotetext{
${ }^{11}$ Warner's fourth parameter for counterpublics is that "a public is constituted through mere attention" (87).
} 
individuals in the gay community, while their common membership in the group was confirmed by their interactions in these spaces. The usefulness of gay meeting places is highlighted in Teleny as Des Grieux embraces his sexuality and learns to enjoy the company of likeminded men.

In addition to creating the physical outlines of the counterpublic and helping shape the identities of its members, space is also deployed in Teleny as a metaphor: Orientalism, and its fascination with the spaces of the east or Middle East, operates as shorthand for sex, sensualism, and superstition. ${ }^{12}$ Joseph Allen Boone's "Vacation Cruises, Or, The Homoerotics of Orientalism" documents this trend, citing travelogues and letters from famous travelers such as E. M. Forster, Oscar Wilde, and Gustav Flaubert as well as other "non-literati," all rich with accounts of homoerotic escapades in North African and Near Eastern countries (90). Boone says, "the possibility of sexual contact with and between men underwrites and at times even explains the historical appeal of orientalism" ("Vacation Cruises" 90). Cook agrees, noting that many gay figures "transgress boundaries, between public and private and east and west, for example, but they also reaffirm them, since it is the act of transgression itself which is rendered erotic" (116). Knowing this code, we can see that Teleny's Hungarian origin makes him an exotic erotic object and hints at his aberrant sexuality. Briancourt's home is decorated in lavish eastern wares, and Des Grieux's narration goes on for pages about his tapestries, furniture, vases, and more. The space, layered in Orientalist finery, indicates the queer sexual activity that goes on there. Similarly, the location of the visions shared by Teleny and Des Grieux are exotic and

\footnotetext{
${ }^{12}$ I explore Orientalism in relation to sexuality and spirituality at great length in Chapter III, and consider its usefulness in expanding the project in the epilogue.
} 
easternized, layering the coded meanings of Orientalism on the already-potent symbolism of the figures in the visions themselves.

\section{II. "The Mysteries of Love"13}

Des Grieux not only criticizes the general public's treatment of sodomites, but also touches on Christianity sarcastically for its role in opposing homosexuality and its narrowminded approach to spirituality: "are we not born with a leaden cowl—namely, this Mosaic religion of ours, improved upon by Christ's mystic precepts, and rendered impossibly perfect by Protestant hypocrisy" (49). ${ }^{14}$ Later, he 'curses' dominant norms, an aspect of secular society and religion together, saying, "I cursed this beautiful world of ours - this paradise, that man has turned into a hell. I cursed this narrow-minded society of ours, that only thrives upon hypocrisy. I cursed our blighted religion, that lays its veto upon all the pleasures of the senses" (89). Des Grieux describes the straight-laced and proper public as "mealy-mouthed," "over-nice," and "demurely prim," all in the same paragraph, which ends, "at any cost, appearances must be saved" (111). The negative portrayal encourages the reader to sympathize with the homosexual counterpublic already discussed, but also to foster understanding of an alternative spiritual

${ }^{13}$ A phrase used in Teleny, emphasis mine (36).

${ }^{14}$ In an insightful moment of religious reflection with the auditor, Des Grieux actually posits that sinful men (in this case, sodomites) are actually closer to the Christian God than virtuous men, because "it is the sinner and not the saint that needs a Saviour, an intercessor, and a priest; if you have nothing to atone for, what is the use of religion to you?" (136). 
community. This second counterpublic included members who were interested in superstitions, belief in phenomena like telepathy, haunting, prescience, and other unexplainable events.

It is no surprise that supernatural connections play a central role in Teleny: Victorians were very interested in mystical and supernatural concepts, which revolved closely around the ways people are tied to each other and how those ties are organized or strengthened. Pamela Thurschwell, for example, describes this trend as "questions [...] about what separates one mind from another and what separates the living from the dead" (2). She goes on to say, "Occult ways of imagining cultural transmission and communication [...] are used by a wide variety of writers of the period to create phantasmatic spaces in which they redefine intimate, sexual, familial and national ties between people against the usual patriarchal models" (2). While mysticism encouraged the testing of boundaries of social norms, agreed upon by hegemonic authority, it opened a venue for the creation of new modes, new authorities, and allowed for new "supernaturally enhanced intimacy" between members of new communities (Thurschwell 3). Most important to Teleny were contemporary concepts related to these connections and communication between connected individuals, or, as Teleny says, "the transmission of thought, of feelings, of sensation" (15). The term "telepathy" had just recently been coined (in 1882) and had connotations of communications between lovers and "the desire for complete sympathetic union with the mind of another" (Thurschwell 14). The "sympathetic union" between Teleny and Des Grieux is obvious, as is the link between their telepathic abilities and their erotic love. The bonds, created by their love, solidify their communion via the supernatural.

Mysticism's popularity is also evidenced in Teleny by a brief but important historical reference to the Society for Psychical Research (SPR), or, as it is called in Teleny, the "Psychical Society" (57). This reference legitimizes Teleny's inclusion of the mystical counterpublic by 
tying it to its real-world counterpart through naming this contemporary society. In fact, the passage in which this reference occurs attempts to normalize mystical occurrences such as telepathy just as much of the novel attempts to normalize homosexuality, since it points out the skepticism of the auditor and counters doubt with science. The SPR and psychical researchers at large approached the supernatural with a critical, scientific eye, but there were many others who practiced alternative spiritualities with sincerely-held belief. Janet Oppenheim says that the central commonality of the different spiritual groups was a "yearning to realize the universal brotherhood of man," a desire that would legitimize the lives and practices of gay men and, indeed, encourage their (sexual) union as the ultimate expression of sameness (108). Sarah A. Willburn adds that spiritualism could provide "places for communal life in extra spheres apart from the public and private spheres of the real world" (1). So Teleny and Des Grieux fulfill the aims of many alternative spiritual practices with their supernatural connection: they are united in body and mind, and their partnership extends even beyond the gay counterpublic into the "extra sphere" of metaphysical experience.

Alternative spiritualities were common and often sincerely-held beliefs, but they were still alternative in that they did not follow or agree with dominant Anglican beliefs. Though Oppenheim describes several groups in harmony with Christianity, spiritualists were not, by definition, Christian. ${ }^{15}$ Because of their place outside normative culture, spiritualists were often criticized or caricatured by skeptics. In Teleny, this skeptical role is filled by the auditor, who seems to represent the reactions of the dominant public. As discussed above, he asks Des Grieux repeatedly whether he is ashamed of his gay acts, and he also doubts Des Grieux when he

\footnotetext{
${ }^{15}$ For more on these groups, see Oppenheim.
} 
describes his supernatural experiences. This skepticism provides the reader (either contemporary or modern) with an outlet for their own doubt, and by addressing it within the frame story, the reader is persuaded to continue suspending disbelief. More importantly, though, the parallel establishes the connection between the gay and spiritual counterpublics, creating solidarity and sympathy between the two outsider groups, each faced with social stigma.

The individual figures of Teleny and Des Grieux serve to unite the gay community and Spiritualist community within their own relationship such that in the novel the spiritual counterpublic is less a community and more a party of two. But the presence of the historical interest in spiritualism and the brief mention of the SPR help create the sense of community where the portrayal is lacking. Additionally, the visions that Teleny and Des Grieux share create a small community of individuals tied together by the supernatural conflation of their identities: Adrian/Hadrian, Antinoüs, "those two angels which God sent to Lot," perhaps even the populations of Sodom and Gomorrah all become one with Teleny and Des Grieux (7). Much later, Briancourt's desire to paint his lover as "Christ, erect, clasping John" and his proposed title, "Socrates - the Greek Christ, with Alcibiades, his favorite disciple" further involves these historic and religious icons in the small community dedicated to alternative spirituality and same-sex love (119). In Unlimited Intimacy: Reflections on the Subculture of Barebacking, Tim Dean asserts that the modern practice of "bareback" gay sex creates kinship ties between and across wide populations of men and allows connection to a history of other sexual actors via the physical transmission of fluid and the associated actions of community-building across generations. Thus, even though Teleny and Des Grieux specifically engage in alternative spiritual practices in the novel, the gay community and the spiritualist community serve to 
enhance each other via the connections made between the men in the novel and the historical figures they echo.

One of the most frequent historical references in the novel to a specifically gay spiritualism is through the figure of Priapus; common euphemisms for gay sex acts refer to the Greek god of male genitalia. For example, after being told by Teleny to sit down in preparation for sex, Des Grieux narrates, "He first knelt down to say his prayers to Priapus" (105). But the euphemism becomes a more extended form of alternative spirituality, too-rather than just indicating an act, the "worship" of Priapus becomes real dedication, at least for Teleny and Des Grieux, who represent the pinnacle of unity between the two counterpublics. During the beginning of their relationship, Des Grieux tells the auditor that he spent the night with Teleny and that "As true votaries of the Grecian god, we poured out seven copious libations to Priapus - for seven is a mystic, cabalistic, propitious number" (109). Though it is clear throughout that both men are believers in the supernatural, their Priapism heightens their physical, erotic connection as well as their mental and emotional unity. Additionally, the direct connection to the Greek pantheon, popular in many Victorian works, ${ }^{16}$ further ties the men to the larger community of alternative spiritual and gay practices across history.

The characters in these visions and ceremonies help expand the community of supernatural believers, but they also operate as supernatural foreshadowing by combining the identities of complementary individuals - the literary device becomes a form of fortune-telling

\footnotetext{
${ }^{16}$ See Linda Dowling's Hellenism and Homosexuality in Victorian Oxford for an in-depth review of Hellenism and its connections to the gay community. I use Hellenism as a central trope and explore its impact and uses particularly in Chapter IV.
} 
and a form of possession. The connection between the story of Hadrian and Antinoüs and that of Teleny and Des Grieux is so heavy-handed the reader cannot help but draw the comparison and predict the ending of Teleny and, at times, we cannot help but wonder if the spirits of the Greeks are re-living their tragedy in new bodies. The first shared vision the lovers have is that of Hadrian standing on the shore of the Nile, and Des Grieux narrates, "I now began to understand things hitherto so strange, the love the mighty monarch felt for his fair Grecian slave" (6). Des Grieux's "understanding" comes as a sort of sympathy or unity with the ancients, and it aligns him with Hadrian, since his is the love Des Grieux can feel. At the time, Teleny jokingly says, "Who knows, perhaps I shall die for you one day!" (15). Later, Teleny reminds Des Grieux of the vision, saying he is concerned with his "fate" and calling it "prophetic;" Teleny says, "it was something more than idle fancy" (151). Teleny's sense of the vision reinforces their roles, since he clearly sees himself in the doomed Antinoüs. Des Grieux also gives Teleny a ring with the likeness of Antinoüs on it as a love token and they discuss how much it looks like each of them, and near the end Des Grieux even proposes that they escape Europe, suggesting that they "go to the East, where I must surely have lived during some former life," indicating the extent to which he believes himself aligned with historical figures (152). Ultimately, like Antinoüs, Teleny commits suicide.

The vision of Hadrian and Antinoüs is not the only case in which supernatural events have real, physical ramifications, though. There are many examples of Teleny's mystical presence having real effects on Des Grieux: for example, the first time they meet, Des Grieux is inexplicably drawn to the green room and he "felt a strange flutter within," and then is mysteriously immobilized before being "attracted onwards" toward Teleny, who "seemed to be slowly drawing [Des Grieux] to him” (9). Teleny’s power over Des Grieux is not only mental 
and emotional, but physical as well. The mystical connection is reciprocal, though, and we find out that when Des Grieux is attempting to avoid his feelings for Teleny, the pianist suffers and is physically unable to play concerts to the best of his ability: Des Grieux narrates, "from the very day I had ceased to attend his concerts, he had been playing wretchedly" (81). On the other hand, when the lovers are in each other's presence and good graces, their supernatural bond can enhance their love, their talents, and their lives; it is life-giving and creates art, demonstrating the ways the supernatural can influence the real.

The mystical can clearly have physical impacts, but supernatural effects can also sometimes be traced back to physical causes: in Teleny there are many references to the specific conditions surrounding the cases of spells, trances, and mesmerism. When Teleny and Des Grieux first meet, they shake hands without gloves on, and the touch of bare skin seems to physically allow for some kind of magical transmission; ${ }^{17}$ Des Grieux calls Teleny's hand "magnetic" and says, "I actually felt I was being taken possession of, and I was happy to belong to him" (11). This last detail—his willingness to be possessed—is an important factor in actual possession, during which a medium must have special conductive properties: Willburn clearly says, "becoming possessed is a certain physical ability" (6, emphasis mine). In addition to the mesmeric subject's acceptance, the power of the physical touch is integral to a spiritual "touch"-bodily intimacy encourages intimacy of the mind. This mental influence is what allows Des Grieux and Teleny to share visions.

${ }^{17}$ In Chapter V, I discuss a similar, gloveless touch in Penny Dreadful that develops sexual tension and spiritual transmission between Vanessa Ives and Dorian Gray. 
During the very first time that Des Grieux attends one of Teleny's concerts, they share a vivid hallucination. Des Grieux acknowledges that he has the same vision as Teleny readily enough, and Teleny passionately compares their interests to prove that their connection is supernatural, too - that they are perfect for each other. During this first vision, importantly, the two men lock eyes across the concert hall. Teleny's eyes are frequently described in terms of their prescience and mesmerizing abilities. When Teleny is walking Des Grieux home after their first meeting, Teleny looks into his eyes with "demoniac fascination” and, a moment later, "stepped back, and shuddered as if he had received a strong electric shock," faint and weak as if he has just put forth some kind of exertion, as if he were mesmerizing Des Grieux just by looking into his eyes (17). ${ }^{18}$ This electric connection is what begins to unite them, and a moment later, Teleny emphasizes the importance of their eyes and their union: "our glances met, and then there was a current between us, like a spark of electricity running along a wire" (18). Teleny's eyes continue to be a source of mystical fascination throughout the novel, though, far beyond this first shocking contact. In fact, his eyes are the first thing Des Grieux fixates on when recounting his story; his "glances" are the earliest hint we get that the men will have a connection, and then Des Grieux tells the auditor all about his eyes, “dreamy,” with a "penetrating power," and although usually composed, his eyes betray that he occasionally has "a scared and wistful look, as if he were gazing at some dreadful dim and distant vision" (5). Here is our first indication that Teleny can see the future.

\footnotetext{
${ }^{18}$ For an in-depth discussion of Victorian mesmerism, including the importance of eye contact and touch, see Alison Winter's Mesmerized. I discuss mesmeric practices in greater detail in Chapter III.
} 
Teleny's hands, eyes, and even speech are all part of his magic: in addition to the possessing handshake and his eyes already discussed, Teleny uses his native language to entrance Des Grieux the evening of their introduction. After they agree to be great friends, Des Grieux narrates, "thereupon he clasped me again to his breast and muttered in my ear some words of an unknown tongue, so low and musical, that they almost seemed like a spell" (18). ${ }^{19}$ It is, of course, only the skepticism in Des Grieux, or only his unwillingness to appear too superstitious, that prevents it from being a spell instead of "almost seeming" like one. And with any unexplainable phenomenon, the "seeming" might as well be "being" because the effect is one and the same: Des Grieux is transfixed and madly in love with Teleny. Indeed, the next morning he is lovesick for the pianist and wakes with his own sort of incantation: "The name of Réné [Teleny] was ever on my lips. I kept repeating it over and over for dozens of times” (22). Throughout that day, Des Grieux continues to feel the effects of the spell, saying, "[Teleny] actually haunted me, his voice [...] was ever repeating in those unknown accents," so Teleny's “spell” lingers in Des Grieux's mind, emphasizing its power and their supernatural connection, and he complains that the pianist has "bewitched" him $(27,26)$. The language of spell-casting helps reinforce the supernatural bond between the two men, adding to Teleny's mystical sight and electric touch.

Teleny emphasizes Des Grieux's willing participation in the relationship (after his first reluctance), but this "spell" cast by Teleny could be read as a form of coercion or dominance. In

\footnotetext{
${ }^{19}$ Later, the "spell” is repeated; after saving Des Grieux from jumping off the bridge, Teleny "whispered softly, in that unknown tongue of his, some magic words which seemed to sink into my soul" (90).
} 
her introduction to the novel, Amanda Caleb is careful to point this out, saying that the spell "does help to explain why [Des Grieux] is so drawn to [Teleny], despite having had no former homosexual experiences or clear longings," and further explains that according to the SPR, such a spell or hypnosis can lead to other mystical transmissions, like the visions that happen throughout the novel (xv). But I would argue that aside from establishing the power roles of the relationship (Teleny is experienced and has a dominant personality, while Des Grieux reluctantly and shyly enters the relationship and gay community), Teleny's possible spell only serves as the catalyst which draws the men together and enables their connection, not some kind of magic that makes Des Grieux suddenly gay. ${ }^{20}$ Rather, the men are mutually infatuated with each other. Teleny's early realization that he has found a "sympathetic listener" for his music and his obsession with seeing Des Grieux in his audience prove that Teleny needs Des Grieux as much as vice versa (11).

Many of the visions and metaphysical connections between the men are reciprocal or allow one to simultaneously sense the other, and there are many qualities that create a sameness or equality between them. Through their visions, they are connected despite physical location, and are united as a sort of single being, not individual but joined by supernatural bonds into communion. Their metaphysical bond is dependent on their shared sameness. This doubling effect is paralleled by the men's physical appearance, which is described several times in terms of similarity or likeness: for example, Des Grieux says, "I stared at myself within the looking-

${ }^{20}$ Des Grieux repeatedly tells his auditor that he has never been attracted to women. For example, when he tells the auditor of his first attempted romance, he concludes, "the fact is, I had really never cared for her or for any other woman" (32). 
glass, and I saw Teleny in it instead of myself" (23). Their shared tastes also make them doppelgängers: when they first meet, Teleny guesses that Des Grieux's favorite scent is "Heliotrope blanc" because it is his own favorite scent; he says, "all our tastes are exactly the same, are they not?" (16). Indeed, the novel frequently discusses doppelgängers and their superstitious importance; Teleny says, “you are, perhaps, my doppelgänger? Then woe to one of us! [...] In our country they say that a man must never meet his alter ego, it brings misfortune to one or to both; [...] I am superstitious, you know" (114). Membership in this spiritual counterpublic, then, is illustrated by the admission of belief in the importance of "superstitions." Because the men give weight to their mystical experiences and discuss them in dialogue, they self-select into the larger group of spiritualists. Despite this superstitious fear of doppelgängers, Teleny and Des Grieux dress alike to go to Briancourt's party and are seen so often together that the general public "ended by not being able to think of one apart from the other" (138). Thus, even observers consider the two men a unified pair.

The unity of Teleny and Des Grieux as doppelgängers has a number of ramifications within the story itself. For example, after Teleny's tryst with his duet partner, she conceives a child who looks like Des Grieux (62), ${ }^{21}$ and Des Grieux is said to look like his mother (142), which could partly explain or excuse Teleny's willingness to have sex with her. But perhaps more important are the implications for careful readers: as the party at Briancourt's house

21 Though Des Grieux narrates repeatedly that he and Teleny were similar-doppelgängers, even - the novel is very clear that the baby looks like Des Grieux. This textual paradox may be evidence of the shifting authorial voice scholars point to when discussing Teleny's collaborative origins. 
signifies the importance of multiplicity and fluidity in the gay community, so the doppelgänger theme reveals the potential of a supernatural bond for creating a multiplicity of identities, conflated identities (like with the historical figures discussed above), and even a single identity shared between two bodies. Willburn develops this theory of "Possessed Individualism," in which one body does not equal one person, and calls it "synchronic complicity," indicating that the shared identity necessarily also shares time and space, which would assist in things like their shared visions (14). Teleny and Des Grieux thus become paradoxically symbolic of both multiplicity and supernatural unity within the gay community, in mind and body.

\section{The Union of Bodies and Minds}

The two counterpublics of mysticism and homosexuality overlap in the figures of Des Grieux and Teleny and are complimentary because of their similar marginal status and the ways each supports the self-defined identity of the main characters. The authors of Teleny may have been keenly aware of the counterpublics they were representing and creating: the title of the novel encompasses both. The name "Teleny" bears marked resemblance to "Telepathy," which, as I noted above, was a recently-coined buzz word referring to experiments in popular mysticism and pseudoscience. The alternative title, "The Reverse of the Medal," is a reference to "the back side" or anus, indicating male homosexuality (13). Alternatively, "the back side" can indicate the reverse of the medal of society: the title tells us that this is a novel not of the public, but of the counterpublic. Now that we have investigated each counterpublic individually, let us turn to their union.

The connection between Des Grieux and Teleny is complex; although more erotic and less religious per se, the lovers find their own transcendental experiences through the exploration 
of their mystical visions and supernatural connection. Caroline Spurgeon describes this as "“erotic mysticism,' that is the love and attraction of the soul for God, and of God for the soul, expressed in the terms of the love between man and [man]" (113). Teleny and Des Grieux are bound together with and by love (or Love) and are bound within several groups, each connection affecting the others. Indeed, when Teleny saves Des Grieux from jumping off the bridge, Des Grieux sees him in very biblical terms: "Was he my guardian angel or a tempting demon?" (89); furthermore, the end of their story could be compared to the death and resurrection of Christ in Des Grieux's (failed) self-sacrifice, and the subsequent suicide of Judas as Teleny stabs himself. But even beyond the Christian story we can see the spiritual importance of their erotic love: Willburn calls this "Spiritual Darwinism," a "spiritually sexual" route to salvation or fulfillment, and she describes the Waisbrooker subset of Spiritual Darwinism, which proposes a path to spiritual enlightenment via sex; she says "spiritual (rather than material) fluid is exchanged" by lovers (72-3). Both of these theories center on the idea that "the mind's advancement relies on the body having sex," and we can clearly see the exchange of visions, identity formation, conceptions of morality, etc. between Teleny and Des Grieux (Willburn 73).

Speaking about several fin de siècle authors, Thurschwell says that "writers employ magical thinking as a powerful tool to expand the potential effects of consciousness and the possibilities for intimate ties and identification" (7). Thus, the telepathic communications, prescient and metaphysical visions, and deep erotic connections that Teleny and Des Grieux share foster mystical bonds and a sense of communion. Similarly, their sexual experiences within the framework of spiritualism "make a single identity impossible and replace it with a plural one," compounding their doppelgänger nature (Willburn 88). Their sex and their magic blur distinctions between self and other, individual and community, and even definition and 
vagueness: their membership in each community "enables different types of social and selforganization" (Willburn 117). Gray and Keep are worth citing again here, as what they say of the gay community easily also applies to the supernatural ties between Teleny and Des Grieux: the "emphasis on multiplicity and exchange seeks to subvert the construction of the [identity] as singular and identifiable and to replace the certitudes of individuation with the pleasures of anonymity and collectivity" (201). Thus, Teleny and Des Grieux have opportunities to shape their relationship and their position in the two counterpublics because of the flexibility and decentralized natures of identity definition. The interactions of the two groups, which build upon each other, demonstrate the productive potential of combining the spiritual with the erotic.

The initial meeting and first shared vision of Teleny and Des Grieux, which sets the stage for their entire relationship, combines supernatural hallucination and sexual arousal such that the telepathic connection is equated with its erotic subject. The mysterious vision of Antinoüs shared by Teleny and Des Grieux is spontaneous but loaded with meaning: the story of Hadrian's relationship with Antinoüs is an example of "the narratives and fantasies around which the literary homosexual community structured and powered itself" (Waters 195). ${ }^{22}$ As described above, the comparison with historic figures adds to the scope and perceived validity of the gay community. Moreover, this first vision sets the standard for prescient and supernatural visions; in this case it is a darkly foreboding vision of love and death. Thurschwell says that telepathy is an "erotic fantasy of minds and bodies merging," and so the romantic aspects ("minds") of the Antinoüs vision prophesy their intensely intimate physical relationship ("bodies") (8). The

\footnotetext{
${ }^{22}$ For more on the story and Victorian fascination with Antinoüs, see Sarah Waters's article “"The Most Famous Fairy in History': Antinoüs and Homosexual Fantasy."
} 
"merging" of their bodies and minds in this mystical way echoes their physical likeness and creates a mental or spiritual doppelgänger effect. Thurschwell's assertion that telepathy is, by definition, erotic is easily evidenced by the times telepathy occurs in Teleny.

The first time he ever hears Teleny play, Des Grieux describes his experience, saying "I was spell-bound [...] the strangest visions began to float before my eyes" (6). He sees eastern lands, symbolizing, as he says, "the blasting lust of men," and then the vision of Antinoüs (6). The visions are accompanied by Teleny's piano and cause physical lust to stir in Des Grieux as a phantasmagoric hand caresses his lap and his "brain began to reel" (7). Des Grieux ejaculates as the music reaches its crescendo - the synchronized effect is directly caused by the pianist himself. This episode comes almost immediately upon the start of the novel; it gives readers the first vision, revealing the inclusion of mysticism in the story, and it also gives us the first erection and climax, graphically portrayed. The two themes are thus solidly united from the very beginning (of the novel and of Teleny and Des Grieux's relationship) and indeed, each major instance of supernatural activity is accompanied by sex. Mysticism and eroticism are tightly interwoven to illustrate the potential power of spirituality to enhance or validate the gay relationship and each man's self-defined identity.

The vision of Hadrian and Antinoüs symbolizes the love Des Grieux feels for men, but there are numerous occasions when the visions he (and Teleny) have are seemingly heterosexual. However, largely due to their doppelgänger natures and their reciprocal telepathy, I argue that the opposite-sex erotic acts can also be read as same-sex acts with possessed or haunted substitute figures, which aids in our understanding of the link between mystical and gay identities and the ways in which Des Grieux especially navigates identity formation and 
counterpublic membership. Though sexuality was not yet entirely central to identity, ${ }^{23}$ morality and social standing were key concerns, and Des Grieux's struggles with his same-sex desire and its social stigma play out via these heterosexual scenes and, as he narrates, "what is morality but prejudice?" (46). The telepathic link thus becomes a way for Des Grieux to passively convert his self-conceptions of sexuality from socially- and morally-acceptable (heterosexual) to what he feels is "natural" (homosexual), while also providing commentary that would have reassured the contemporary gay audience of their own life choices.

The night that he meets Teleny, Des Grieux has a disturbing dream about having sex with his (non-existent) sister. The dream is lightly foreshadowed when Teleny gives Des Grieux his white heliotrope button-hole and hopes that the smell of the flowers will make Des Grieux dream of him (16). Des Grieux begins to describe the dream as if Teleny is the central sexual object, saying, "it seemed to me that Teleny was not a man, but a woman; moreover, he was my own sister" (18). Establishing a parallel between a lover and a sibling helps draw attention to their doppelgänger natures as described above because of the perceived sameness between siblings. More important, though, is the taboo against incest, which helps Des Grieux work through his taboo desires for Teleny while still clinging to heterosexual trappings. He resists his desire for his dream-sister, just as he resists his same-sex desire for Teleny, based on social stigma and the perceived moral problem. But the dream, like the novel, ends with Des Grieux's capitulation and

\footnotetext{
${ }^{23}$ Foucault places the solidification of the "deployment of "sexuality" "at "the end of the nineteenth century," saying that it was made possible "with the development of the juridical and medical control of perversions," and that it was not until then that the concept "spread through the entire social body" (122).
} 
ultimate relish in ravishing the object of his desire and then, suddenly, his mother's involvement bringing about the complete ruin of his joy. While this ending could foreshadow the end of his relationship with Teleny, the conflation of incest and homosexuality acts as a more immediate way for Des Grieux to grapple with his love for Teleny and his shifting opinions on "a most heinous act," with which he eventually comes to peace (18). The role of the supernatural in this dream sequence is two-fold: the dream is a type of projection of Des Grieux's feelings for Teleny into the body of a sister, and the dream itself is perhaps a magically-induced sleeping vision caused by the suggestive spell of Teleny's button-hole. Furthermore, the dream amplifies the established doppelgänger pattern by conflating Teleny with the sister, and by using a sister figure to indicate sibling sameness. At the end of the dream, Teleny is transposed onto Des Grieux as well; when he wakes, Des Grieux wonders, "was this stiff rod I was holding in my hand, mine or Teleny's?" (21). The multiplicity of bodies are all possessed by just one, dreaming Des Grieux - or perhaps we can say that Des Grieux and his dreams are possessed by Teleny. In either case, the sister dream illustrates the potential for heterosexual acts in the novel to be coded homosexual acts and to further link the supernatural to the erotic.

Very similar forces are at work during the episode of the Countess. Though Des Grieux is still resisting his love for Teleny at the time, he follows him home one night and haunts the scene. He narrates, "my mind was so intently fixed upon Teleny that my inward self seemed to disintegrate itself from my body and to follow like his own shadow the man I loved" (50). Because of Des Grieux's projection into Teleny's "shadow," the men are mentally or spiritually linked, and the transmission is reciprocal. And once again, the heterosexual encounter is queered: when Teleny thinks of Des Grieux, he becomes a much more passionate lover. Des Grieux knows that he is foremost in the pianist's thoughts, narrating, "I felt that my image had 
always been present before his eyes" and, later, he wistfully admits he would like to be in Teleny's arms instead of the countess, and "the image which had formed itself within my mind so vividly was all at once reverberated within Réné's brain; and he thought, if instead of this lady's mouth those lips were my lips; and his phallus at once stiffened and awoke into life" (56, 60). The men are mystically linked, and it enhances the sexual encounter largely because rather than having sex with the Countess, Teleny sees himself having sex with Des Grieux. The latter's ability to project his own ideas into the former's head proves that their visions flow both directions. In fact, the auditor and Des Grieux discuss the phenomenon during this scene: the auditor suggests that Des Grieux had merely fallen asleep and dreamt it, but Des Grieux corroborates the story later with Teleny and adds, "there was [...] a strong transmission of thoughts between us," and that their "natures seemed to be bound to one another by a secret affinity," allowing the shared visions $(57,60)$. The "transmission of thought" also results in the Countess having a child that looks like Des Grieux rather than Teleny, again pointing to the metaphysical possession of multiple bodies by one individual and many individuals in one body. Thus the seemingly heterosexual sex is actually supernaturally-enhanced gay sex with the same multiplicity of bodies discussed in regards to the sister dream.

Where Des Grieux's dream-sister reveals anxieties about social norms, Teleny's encounter with the Countess explores the option of Platonic love. She is hesitant to commit adultery, and asks Teleny, "Could we not love each other with a Platonic love? Is that not enough?" to which Teleny replies, "is it enough for you?" (53). She is easily seduced because she understands that her desire goes beyond chaste attraction. Though this scene is ostensibly about heterosexual sex, it also serves to explicitly address why love between men cannot survive without physical connection via the erotic, and they are thus unable to be bosom friends but not 
sodomites. The opposite is also clearly portrayed: sex without love is doomed, especially if the loveless sex goes contrary to natural sexual desires (i.e., straight, loveless sex is the worst option for a gay man, and can only end badly). Though told as a side-story and not involving the spiritual link to include Teleny, the case of Des Grieux's housemaid illustrates the dangers of dabbling in sex without love, and it ends with her death. The point is reinforced by the act of mercenary sex between Teleny and Des Grieux's mother to the extent that Des Grieux attempts suicide and Teleny kills himself. The latter's tryst with the former's mother may also argue that sex without the supernatural connection is also doomed, since it is during this critical moment that Des Grieux's visions fail.

By showing the dangers of sex without love and sex without spiritual connection, Teleny makes a case for the importance of the mystical erotic encounter. The added elements make sex not merely physical and emotional, but transcendent. During what would be their last night together, Des Grieux describes that after their orgasms, they "feel [sic] into that divine prostration which follows shattering ecstasy" (149). Describing their bliss as "divine" emphasizes the spiritual aspect of their union. Dean outlines the potential of gay sex to foster interpersonal relationships and as a way of transcending the individual or corporeal self in Unlimited Intimacy. He says that the transcendent nature of sex causes important psychological and social impacts by breaking down barriers between the self and other. Like the metaphysical multiplicity of identity during telepathically-shared sex with others, the sex between Teleny and Des Grieux also unites them: Des Grieux narrates that after climax, the men were "unconscious of everything save the pleasure of feeling each other's bodies, which, however, seemed to have lost their own individuality, mingled and confounded as they were together. Apparently we had but one head and one heart, for they beat in such unison and the same vague thoughts flitted 
through both our brains" (149). Similarly, after their first night together Des Grieux says, "lust was now the overflowing of the heart and of the mind - the pleasurable harmony of all the senses," indicating not only a physical desire, but an emotional and spiritual need as well (106, emphasis mine).

The union of disparate bodies and the subsequent mystical union of spirits, hearts, minds, etc. also illustrates what Willburn describes as the function of both bodily expression and spiritual expression: "radical roles, or body uses, often work toward achieving such values as love, equality, beauty, pleasure, natural order, domination, subordination, promiscuity, and collectivity within a single body" (2). In its broadest sense, also espoused by Dean, "promiscuity" is the very openness to these experiences and the unity with the other felt by Teleny and Des Grieux. "Promiscuity," then, is about a multiplicity of experiences and their eventual reconciliation within and improvement of the self. Additionally, Willburn says that “mystical personal expression can contribute to aligning society with imaginary spiritual harmony or confronting society with an exiled other" (2). Thus mystical and sexual promiscuity opens the self to the other and the possibility of the unity of the self and other- - or, in other terms, the dissolution of the self and the other. The potential for self-guided identity formation after the dissolution of a socially-constructed sense of self has infinite potential, especially for "exiled" gay individuals.

When attempting to find harmony with the dominant public, one of the most central concepts gay lovers have to grapple with is heteronormative marriage. The concept of monogamy is at odds with much of the multiplicity, group focus, and promiscuity already discussed within the context of the gay counterpublic. Furthermore, the normative religious nature of state-sanctioned marriages precludes alternative spiritual expression. Even though their 
relationship is far from normative, Teleny and Des Grieux often refer to marriage in very conventional ways because conceiving of their love within the dominant framework helps reconcile their feelings of outsider status with a desire for belonging. Des Grieux describes their first kiss, so passionate that their lips begin to bleed: "it seemed as if this fluid, rushing up from our two hearts, was bent upon mingling together to celebrate in that auspicious moment the old hymeneal rites of nations - the marriage of two bodies, not by the communion of emblematic wine but of blood itself” (90). ${ }^{24}$ Their second kiss Teleny calls an “oath,” Des Grieux gives him a ring and calls it a "pledge," and at Briancourt's party they are considered on their "honeymoon" $(93,114,126)$. Similarly, by describing the union in terms of formal promises and more, the novel urges readers to recognize the legitimacy of gay love. Des Grieux himself struggles with the difference between a "criminal infatuation" and "real, heart-sprung, genuine love," but he realizes that the former is only a culturally-damned version of the latter (63). Indeed, it is because the couple is not heterosexual that the authors emphasize so strongly the parallels to straight marriage and reinforce the bond between the men with supernatural events. Doubly supported by normative language and a mystical connection, readers cannot help but accept the legitimacy of Teleny and Des Grieux's union. The novel even goes beyond mere marriage: Des Grieux narrates after their second kiss, "was an oath needed, when we had given ourselves to one another with such a kiss?" and, later, "had our union been blessed by the Church, it could not have been a closer one" $(93,138)$.

${ }^{24}$ The mingling of their blood also echoes Tim Dean's assertions about the meaning of sharing body fluids (in the form of semen) to physically unify bodies. 


\section{A Gay Community of Authors}

Given these readings, Teleny's publication history is noteworthy in that it creates a mirror for the queer community it portrays. The novel was published by Smithers, but Charles Hirsch was the source of the rumor of Oscar Wilde's involvement, as he spread the story of the novel's (supposed) origins, perhaps to drum up demand for the work: Hirsch, a book shop owner and publisher himself, said that Wilde left a wrapped package at his shop with instructions to expect others bearing his card to pick it up (Gray, Keep 194). A second man came, got the package, and then shortly returned and repeated the instructions to Hirsch, and "this procedure was repeated several times over the next few months, until, on one occasion, Hirsch's curiosity got the better of him" and he took a peek at the contents, Teleny (Gray, Keep 194). Another account says that at one point the package was returned merely wrapped in a ribbon, and Hirsch caught a glimpse of its contents in that way (Hyde, History 142). The manuscript, "written in chain-letter fashion," was clearly the work of multiple authors, not even necessarily in direct contact with each other (Gray, Keep 194).

The novel's non-standard authorship reflects the group of "non-standard" (gay) men and the connections it represents. It creates a new space for subversive connections to be made because of its departure from certain socially agreed-upon norms about relationships, agency, and identity. Teleny is especially interesting because it was birthed in the very hey-day of the "monolithic regime of the author" and a time of new and exciting copyright law (Stone, Thompson 15). But the group of writers stands for the larger community of homosexuals, and the process of writing similarly "offers an alternative not only to models of the author as individual 'genius' but to theories of collaborative writing largely modeled on the sexual dynamics of the heterosexual couple" (Gray, Keep 196). Instead of dominant/giving and 
submissive/receiving collaboration partners, Teleny's round-robin group of equals create a homoerotic novel never meant for wide dissemination is subversive. This group of equals operates like Briancourt's secret party, which highlights multiple erotic partnerships and group participation. Thus the creation and text itself are both bound to groups other than dominant. Mirroring Teleny and Des Grieux's long-distance psychic connections, the authors of Teleny were also bound by something metaphysical: perhaps ideologies, desires, or opinions, perhaps just the understanding that they were all members of a specific group with communally agreed upon expectations and rules.

Robert Gray and Christopher Keep come to an important conclusion: "if Hirsch's account is to be believed, Teleny's anonymity preserved not the unique and consequentially vulnerable identity of a specific artist but instead served to acknowledge that the text was, in effect, the work of a community" (194, emphasis mine). Indeed, Gray and Keep go on to say that by naming Wilde the sole or even primary author severely limits the power or authority that the text has as speaking for and among the homosexual community. They say, "Teleny's heteroglossia stands in marked contrast to the individuating tendencies of the 'official' discourses concerning both homosexuality and authorship in the late-Victorian period," discourses which attempted to delimit and describe single or centralized definitions of identities (195). Rather than creating a species out of a temporary aberration (to paraphrase Foucault), Teleny's authorship refuses to be centralized or unified; the writing of the novel varies in style so dramatically that its authors cannot be made into a homogenized type. Simultaneously, since the authors are each writing a part of the same story, they are necessarily united in purpose - as Warner might say, they actively form a group that can only be defined by their own opting-in to the group. These 
seemingly opposing forces make one important thing clear: identity is self-formed, multifaceted, and fluid in Teleny's world.

Furthermore, the mystical and erotic connections between Teleny and Des Grieux echo the connections among the circle of authors, and the underground circulation of the published work parallels the underground network of homosexuality in London at the time. The mixed styles included in the text itself expose the plural authors, emphasizing multiplicities of identities and forcing the reader to consider the disunity of the self. Marjorie Stone and Judith Thompson add, "one cannot consider the couplings of authors without also considering those performed by readers, critics, and literary historians" (Stone, Thompson 23). Stone and Thompson's idea of collaboration as reflected in writing embodies the different levels on which Teleny works: the novel represents a narrative, but it also contains society, the circle of writers, the underground community of homosexuals, and mystical connections between each level. Teleny is well described as a "fin-de-siècle gay-porn chain-letter novel [...which] operates as a textual and sexual meeting place, as well as a space of oriental fantasy and desire where authorial and sexual proprieties are tested and effaced" (Stone, Thompson describing the conclusions of Gray, Keep 30). This "meeting place" is the juncture of several crossroads: not only the gay and spiritual counterpublics portrayed, but also the authors, characters across history, and readers.

If this same "place" is both "textual" and "sexual," does that imply that, to some degree, textuality is sexuality? In this case of multiple authors writing against dominant culture norms, and writing about subjects that are also subversive, this "meeting place" is self-referential. This creates a metacosm of (probably) homosexual men in a writer's circle community writing in a circle about homosexual desires and communities. Indeed, within the novel itself, there is a metacosm in the frame story of two homosexual lovers talking about two other homosexual 
lovers within the context of the homosexual community. Gray and Keep have also come to this conclusion, saying, "the very form of the novel, as a dialogue between men, [...] serves as a model for its communal or collective authorship" (198). They go on to describe the specific techniques used to involve the reader directly, saying, "the use of the second-person pronoun [...] allows the point of reference to slip from the transcriber to the reader [...] The community by and for which the text was written is thus inscribed in the text" (198-9). ${ }^{25}$ This sort of circular reference, author to co-author to written word to character to reader to community and back again, reinforces the bonds within the gay counterpublic and allows for the inclusion, by proxy, of the reader.

The authorship and position of the auditor also allows the reader to participate directly in the multiplicity of identity (a form of possession) described in several scenes above: the reader becomes the auditor via the use of the second-person pronoun and witnesses the sex acts throughout the novel just as Des Grieux watches through telepathy. For knowing, contemporary readers, this may have been a welcome opportunity to hold discourse with the rest of the gay counterpublic. The for-us, by-us style of the novel is presented throughout in ways I mention briefly above: messages of self-acceptance, rejection of social criticism, and openness to samesex love abound in Des Grieux's narrative commentary. On the other hand, the modern reader is not part of the fin de siècle, necessarily gay, or even male, so engaging the reader with the community of Teleny reinforces the message of flexibility and promiscuity of identity formation carried in the novel.

${ }^{25}$ Warner says that "a public is the social space created by the reflexive circulation of discourse" (90). 
The frame story that surfaces again and again in Teleny operates in a similar way to engage both the original audience and modern readers: it emphasizes the existence of the gay community by portraying Des Grieux's current male lover while also creating simultaneity of past and present in a coexisting chronology. Indeed, when we add the fact that the auditor is frequently referred to in the second person, the reader is added to the gay community by identifying with "you," and if we consider that the reader necessarily reads the work after its writing, the act of reading unites past (Des Grieux's relationship with Teleny), present (his telling of the story to the auditor) and future (the story being read after it has been told). Thus, the contemporary (most likely gay) readers could understand their own position within the novel metaphorically as Des Grieux's auditor-lover, literally as erotically involved in the arousing scenes of the story, and within a larger continuum of a gay community across time.

Another pertinent contextual aspect is the fascination of the late Victorians with the text as a material object. Texts have a certain authority regardless of author status (anonymous, singular, plural, or other). Because texts are so closely related to the moment that produces them, they can be considered "a spirit medium" for communication across time and space (Wolfreys xii). A manuscript written in the fourteenth century in England can be read as a new edition in America in the twenty-first century, and so these texts seem to "haunt" us as modern scholars because when we interact with the texts we lend them "life and volition" (Wolfreys xiii). The temporal and spatial ground covered by a text gives it an aura of permanence and authority and helps form connections between all the disparate origins and audiences exposed to the text. In this way, the publication history of Teleny represents both the gay community (in its authorship) and an analogous alternative spirituality (in the spirit of the text itself). 


\section{Conclusion}

While the formation of an individual identity is largely portrayed as self-constructed, as evidenced by the overarching struggle of Des Grieux to come to terms with his homosexuality, it is always shown in relation to dominant norms, just as the counterpublic community of individuals is always formed in relation to a dominant public. Because of this constant referencing back to hegemonic norms and perhaps the authors' Victorian realism, the conclusion of the novel does not promise sunshine and rainbows to gay men despite its passionate and positive portrayal of them throughout. For Teleny and Des Grieux, what holds their relationship together is their supernatural bond, and once the "uninterrupted current" is broken, the relationship falls apart (18). We see hints of this core dependency early in the novel when Des Grieux is avoiding Teleny's performances in the hopes of suppressing his love for the pianist: Teleny's playing suffers, evidence that disruptions in their mutual love have drastic, real consequences. This episode is minor, though, because the two have not yet become lovers and united to their highest potential both sexually and spiritually. Once they are fully united, their separation is all the more disastrous: Teleny's dishonesty and Des Grieux's inability to see Teleny and his sex partner via their telepathic connection results in the deaths of both men and their relationship.

The novel sets up several episodes of shared visions, and one especially important precedent to the final scene: that Des Grieux was able to see Teleny having sex with the Countess from the street via their telepathic connection. Since Teleny later confirms the entire story, we can trust that Des Grieux is truly able to see Teleny having sex even when he is not in the room. In contrast, the final scene is set with irony when Des Grieux tells the auditor he had paid Teleny's debts but that "Fate_blind, inexorable, crushing Fate" prevented him from telling 
Teleny so (153, emphasis mine). There is also a dark omen just before Teleny leaves for the train station: Des Grieux jokes (sincerely) that he is worried Teleny will be unfaithful and mentions his own mother, and just then Teleny drops a mirror, which shatters. ${ }^{26}$ The combination of "Fate" and the "dreadful omen" indicate that Des Grieux, at least, is still a believer in the supernatural, but that perhaps he has lost the ability to control or invoke his own participation in it (153).

Then, for the final scene during which Teleny is having sex with Des Grieux's mother, Des Grieux's mystical vision fails. Instead of knowing Teleny is at home, Des Grieux first sees a faint light on in his house. And, much more importantly, he watches at the keyhole for several minutes without knowing with whom Teleny is having sex-or even if it is Teleny. Des Grieux narrates, "Was I dreaming_-was this a dreadful nightmare?" and "I could not feel sure that I was alive and awake," proving that his ability to navigate his visions has completely failed him (159); he is suspended between reality and vision, and confuses the two. But he comes to his senses and says, "this was, then, no illusion-no vision," clearly admitting that his connection to Teleny has failed (159). The eventual realization that it is Teleny and his mother sends Des Grieux into a shocked panic, and he runs from the house into the street. Thus, the end of the novel is disastrous for both men after their connection fails.

Yes, both Teleny and Des Grieux die - they cannot live without each other. Each commits suicide in his own way: Des Grieux jumps from the same bridge he contemplated jumping from before entering the relationship with Teleny, creating a frame for their time

\footnotetext{
${ }^{26}$ This detail also may foreshadow Teleny's death, as, like Dorian Gray, he breaks an image of himself.
} 
together bordered by death. He narrates, "I found myself standing on the bridge — nay, on the very same spot on which I had stood some months before" (164). His death is only symbolic, though, as he is saved by his doppelgänger, his "own image," "exactly like" himself, and he wakes in the morgue (164). ${ }^{27}$ This resurrection, as discussed above, reinforces the deeply spiritual connection the men have by linking their lives and deaths to that of Jesus and Judas. Furthermore, at the time of Des Grieux's attempted suicide, Teleny is still alive and so, it could be argued, Des Grieux is unable to truly die while his love lives. But their connection has been interrupted, and they cannot survive together without the mystical union. Des Grieux's attempted suicide demonstrates despair in betrayal, a link to normativity readily understood by any reader - the novel illustrates how dangerous dishonesty, infidelity, and financial problems are, regardless of sexual object preference. The relatability of the causes of the downfall of their relationship help normativity reclaim the end of the novel while simultaneously proving that the commonalities between gay men and the dominant public are significant, thus also legitimizing gay love.

Unfortunately, Teleny's suicide reinforces some of the most dangerous normative aspects of the dominant public and his death allows them to reassert their preeminence. While it could be argued that, like Des Grieux, Teleny dies of despair at lost love, several factors contribute to a different reading of his death: he is the transgressor, having lied to Des Grieux, he is the adulterer, and he waits three days before committing suicide. That he is at fault suggests that his

\footnotetext{
27 The stranger who saves him seems to be a true doppelgänger (not Teleny again, or some metaphorical internal force), and the strange recurring image of sameness being used in such different contexts is likely due to the shifting authorial voice.
} 
suicide is guilt-based, and the delay implies careful, though probably distraught, debate about what to do - not a case of passionate despair, rather a deliberate decision. Teleny is also the partner with more homosexual experience and a more firmly sexualized identity (because of his established place in the gay counterpublic), thus his death becomes a warning against these specific sins and reasserts the public obsession with straight chastity. On the other hand, Teleny's first and final transgressions are having sex with women, so the ending warns us, as Des Grieux argues many times, that going against one's sexual nature is dangerous. Sexual object preference, portrayed in the novel as innate, should not be denied or crossed. The portrayals of Teleny's sex acts with women serve to point out the dangers of sex without love, but the final episode with Des Grieux's mother also reiterates that gay men's attempts at circulating within the heteronormative public can be difficult and the results traumatic. This reading condemns society for judging the gay community as harshly as it does, but it is Teleny who ultimately gives in to normative pressures. His suicide echoes the Spahi's suicide, each death conveying the fear of social stigma and its serious consequences.

Though he lives, we find that normative social pressures have worked on Des Grieux, who says that after Teleny's death, “the earth rose against me; for if Society does not ask you to be intrinsically good, it asks you to make a goodly show of morality, and, above all, to avoid scandals" (169). But only one page later, the narrative ends — we do not see Des Grieux disgraced or exiled, we are only left with the certainty that he has learned to love again. In this way, gay men, like those in the original reading audience, are given hope by the novel: Teleny's is only an individual death, and the end of their coupling is the end of only one relationship. Des Grieux's relationship with the auditor proves that the gay community has survived and Des Grieux continues to operate within it, forming new links with new lovers and extending the 
supernatural current beyond his first romance - all the way from Hadrian and Antinoüs to the modern reader. The combination of sex and spirit allows this connectivity to operate across time, distance, and bodies: the counterpublics foster acceptance and unity while honoring individual identity and multiplicity. 


\section{Chapter 2: POSSESSION AND THE PICTURE OF DORIAN GRAY:}

“The Terrible Pleasure of A DOUBLE LIFE"1

What hasn't been said about The Picture of Dorian Gray? Oscar Wilde's only novel has generated and sustained a "busy scholarly field" since its first publication in Lippincott's Monthly Magazine in 1890 (Bristow xxxiv-v). Dorian himself, as a figure of the fin de siècle, a gothic, decadent, and aesthetic character, and (as is often argued) an extension of Wilde, is discussed in any number of contexts: his personality is psychoanalyzed, ${ }^{2}$ and he is simultaneously "the embodiment of artistic perfection" (Bristow xi), and immoral, insincere, and dangerous. ${ }^{3}$ The Faustian exchange of Dorian's soul transferred to his portrait is a "clever narrative device" (Bristow xi), or maybe it's all in Dorian's head (Tyson). And perhaps the greatest mystery of all is Dorian's sexuality: though he falls desperately in love with a woman, he is also the object of Basil Hallward's "excessive romantic passion" and captivates the attention of Lord Henry (Bristow xiii). The variety and complexity of available readings of The Picture of Dorian Gray prove that it embodies Wilde's claim in the novel's preface, added in 1891: "It is the spectator, and not life, that art really mirrors" (3). ${ }^{4}$ The "spectator" is not

\footnotetext{
${ }^{1}$ Dorian 147.

${ }^{2}$ See, for example, Wenaus on narcissism, Carroll on guilt and evolutionary psychology, and Tyson on psychological disorders such as autoscopic vision.

${ }^{3}$ For the largely negative reactions to Dorian and the novel, see contemporary reviews like those in the Daily Chronicle and especially the Scots Observer.

${ }^{4}$ Wilde also expresses this sentiment in his response to the Scots Observer review, saying, "each man sees his own sin in Dorian Gray" (qtd. in Bristow xxiv).
} 
necessarily only the critic, but also contexts, ideologies, and social norms that are reflected in the mirror of art.

In 1890s London, homosexuality was a crucial social issue, and so the "sins" of Dorian were read as sodomy. While other, more explicit books, such as The Sins of the Cities of the Plain, and events, like the Cleveland Street Scandal, made London citizens widely aware of the gay community's presence, queer individuals of various sorts were still ostracized, scorned, and even occasionally prosecuted. Additionally, The Picture of Dorian Gray is often compared to its creator, and many critics see Dorian's sexuality through the lens of Wilde's. During Wilde's trials for "acts of gross indecency" under the Labouchere Amendment of 1885, Dorian was introduced as evidence that Wilde had "designed and intended" the novel to be "understood by the readers thereof to describe the relations, intimacies, and passions of certain persons of sodomical and unnatural habits, tastes, and practices" (qtd. in Cohen 128). Ed Cohen explains that this interpretation of evidence relies on the "far from self evident" assertion that the relationships between male characters in The Picture of Dorian Gray reflect Wilde's own sexual relationships or preferences, and that it "fixes the literary work as a form of (in this case, counterhegemonic) sexual didacticism" (128). Though these are both accusations that Wilde specifically denied in his responses to reviews and in the 1891 preface to the novel, the associations between Dorian and Wilde as having same-sex desires and erotic encounters have been taken for granted. Thus, it is relatively simple to argue, as many critics do, that the reflection of Wilde in Dorian points to the character's homosexuality.

Though the novel's possible portrayal of sexual activity garnered much initial attention, the portrait itself is equally crucial in allowing the text to operate: the narrative hinges on the fantastic aging of the painting instead of the man. Dorian becomes suspended in time, an 
unchanging body undisturbed by past sins or future decay. Jack Halberstam calls this perpetual present "queer time," which is a method of denying heteronormative "conventions of family, inheritance, and child rearing," reinforcing Dorian's liminality (“Queer Temporality” 2). This suspension puts him outside linear time and its social ramifications, which Elizabeth Freeman calls "chrononormativity" (xxii). While his body is suspended in the present, the novel also indicates circular chronology in its use and re-use of certain events, tropes, phrases, and figures. These temporal disruptions help illustrate Dorian's queerness and his potential for alternative modes of being while also revealing different ways "time magic" can operate as one of the supernatural aspects of the novel. Kingsley Amis and his colleagues explain that "time magic," which they also call "time-slip," can operate to "[provide] access to remote times in which the realm of the spirit can be addressed" (134, emphasis mine). Thus, Dorian's existence outside chrononormativity reinforces the connections between liminality and the metaphysical. "Timeslip," as defined by Amis et. al., is a transition across or through time between subjects, and thus is inherently associated with transitions across and between bodies (for example, a character from the past inhabiting the body of someone in the present of a story), which links a "magical takeover of [the] body" akin to possession and queer temporality (138). So, it is not only the portrait's ability to keep him youthful that shapes Dorian; the portrait also contains his soul and creates queer time, leaving his body empty and available for possession by others.

Possession and, more generally, mysticism and alternative spiritualism were popular among the late Victorians. Spiritualists in the fin de siècle were especially interested in a "more powerful extra sphere, making the real world and civic order undesirable by comparison" (Willburn 49). Dorian's queer identity allows him to travel among many physical locations in London, and his link to the supernatural portrait grants him access to this "extra sphere" as 
well—indeed, his "real world" aging body and the "civic order" of high society are certainly not preferable to the freedom and beauty the portrait's magic brings him. But even more specifically, Dorian presents several types of spiritualism as they were practiced at the time: the novel incorporates the cultural atmosphere that was interested in exploring the connections between the material world and its metaphysical counterpart. Spiritual Darwinism is one of the belief systems that attempted to unite or at least travel between the two worlds using sexual union (Willburn 72), and Dorian's actions indicate he is a believer in using sex to experience the spiritual. Additionally, some of the fundamental questions underlying Anti-Christian Spiritualism about free will and responsibility lie at the heart of Dorian's refusal of agency. Thus, the novel not only portrays the supernatural in the magical painting, but it also engages with real spiritualist movements of its time.

Contemporary interest in aberrant sexualities and various kinds of mysticism, viewed in combination with Wilde's own fluid sexual identity and philosophies and the novel's portrayal of non-linear time, result in a fantasy that presents the potential of otherness and the advantage of multiplicity in the figure of Dorian Gray. Though Dorian seems to be the poster child of the upper classes (beautiful, wealthy, young, well-connected, etc.) his sexuality and unfixed identity push him away from central social norms and toward queer liminality. His queer position leads to a progression uniquely tied to the supernatural and magical in the novel: his intense desire to remain young and beautiful while his portrait ages creates a self-fulfilling cycle of queer activity and possession by others. Dorian's wish for his portrait to age instead of himself is essentially a wish that his queerness remain invisible; the magical internal logic of the novel, fed by related pseudo-sciences like phrenology popular in the first half of the nineteenth century, believes that a person is beautiful as a result of being virtuous. Thus, Dorian's desire to remain beautiful is a 
desire to divorce his actions from their consequences - if he were to commit the sin of sodomy, no one would know because the portrait, not his own body, would become increasingly ugly. His wish results in magic that enables Dorian to remain queer without fear of the consequences and frees him to increasingly explore his queer sexuality and identity, and by giving up his agency he welcomes the control of others, as I explore at length below. He also untethers himself from linear time, since his portrait will age instead of himself, doubly separating himself from consequence as queer time allows him to have a "stretched-out adolescence" and no adulthood (Halberstam, “Queer Temporality” 153). Though he lives through his years, they leave no mark and he does not mature.

Dorian's ability to circulate in different worlds and outside chrononormativity is an intrinsic feature of his queerness insofar as it originates in the flexibility of his identity and his desires. His queer sexuality fuels his wish to both remain within and operate outside normativity and gives him the power to create the magic that allows such circulation, opening for him the possibility of expressing and potential for exploring non-normative activities and non-singular identity. The magic of the picture erases consequences and time, allowing Dorian to freely try a variety of sensual, aesthetic, sexual, and mystical experiences. Dorian's freedom from accountability is also freedom from attachment and fixity, and his identity is not only linked to his sex acts in the novel. Indeed, his identity becomes a constellation of influences, possessions, and interests just as various as his sexual appetites, crafted and shaped by the magic initiated by his sexuality but never solidified or unified. 


\section{Dorian's Sexuality in Context}

When Dorian Gray appeared in the pages of Lippincott's, it immediately received a backlash of negative reviews. An anonymous reviewer for the Daily Chronicle comments on the novel's "studied insincerity" and calls Dorian's remorseful death a "sham moral" (qtd. in Bristow xx). But most reviews also focus on the particular aspect of Dorian's sexuality as cause for alarm. The review published in the Scots Observer is the most forthright about its complaints, specifying that the novel was suited "for none but outlawed noblemen and perverted telegraph-boys" (qtd. in Cohen 124). The spoken-unspoken accusation here refers to the infamous Cleveland Street scandal of 1889, an investigation and series of trials surrounding the discovery of a male brothel that paid post-office boys to "[go] to bed with gentlemen" at Charles Hammond's house at 19 Cleveland Street (Hyde, Cleveland Street 21). The "outlawed nobleman" of the review refers to Lord Arthur Somerset, who was mentioned in the statements of others involved at Cleveland Street but escaped his warrant by fleeing England. The implication of the Scots Observer review, then, was that Dorian's sexual habits were of the same nature as the noblemen who patronized Hammond's Cleveland Street house. Thus, from its time of publication, Dorian has been associated with male homoeroticism through contextual associations.

Indirect textual evidence also points to non-normative relationships and forms of desire: as Eve Kosofsky Sedgwick says matter-of-factly, "(biographical hindsight aside) the triangular relationship of Basil, Dorian, and Lord Henry makes sense only in homosexual terms" (BM 176). Sedgwick elaborates in Epistemology of the Closet, arguing that since it was published before Wilde was "outed," The Picture of Dorian Gray "is in a sense a perfect rhetorical distillation of the open secret" (165). Jeff Nunokawa agrees, and says that the open nature of Dorian's sexual 
secret is what gives it strength: "Made lustrous now by all the muted lighting of indeterminacy, homosexual desire cannot be contained for the very reason that it cannot be confirmed" (22). Although the novel does not openly transgress any heteronormative boundaries, we understand that it is not heteronormative; the "love that dare not speak its name" is present - spoken in its very noteworthy silence. ${ }^{5}$

Though treated as obvious, this aberrant sexual content is still silent: Dorian both is and is not "gay." The undefined nature of his sexual exploits is what allows his identity to remain flexible and open to influence and new experience. Moreover, Foucault places the solidification of the "deployment of "sexuality" at "the end of the nineteenth century," saying that it was made possible "with the development of the juridical and medical control of perversions," and that it was not until then that the concept "spread through the entire social body" (122). So, despite the contemporary reviews and continuous urge to firmly categorize Dorian's sexual identity, contemporary conceptions of self did not necessarily tie an individual to their sexual preferences. Moreover, the trouble with anachronistically mapping the gay identity in Dorian is, of course,

\footnotetext{
${ }^{5}$ Because the homosexual content of the novel is generally taken for granted, critics rarely directly evaluate textual evidence for same-sex attraction beyond a few well-known examples. Jeffrey Meyers attempts to describe the "how" of the novel's sexuality in Homosexuality and Literature, 1890-1930, but even he relies heavily on Wilde's biography and includes few textual references.

${ }^{6}$ As outlined in the introduction, I use this term knowing that it is anachronistic. The implication that Dorian has same-sex desires, though, is certainly accurate for the novel's contemporary audience.
} 
that the novel itself helped define the indicators and behaviors associated with gay men to begin with. As Dirk Schulz explains, not only is Wilde as an author and a public figure "mythologically charged" with meaning, but also "In the case of The Picture of Dorian Gray it has become received wisdom that the novel 'actually' deals with same sex desire despite providing no 'sexual' evidence for such assumptions" $(25,35)$. Indeed, Wilde himself says, "What Dorian Gray's sins are no one knows" in his response to the Scots Observer review which focused so closely on the novel's homosexuality (qtd. in Bristow xxiv). Despite the novel's inclusion in Wilde's trials, "its homoeroticism is veiled and there is no explicit disclosure of London's homoerotic possibilities. The novel instead turns on the possibility of constituting a secret, individualized map of the metropolis which reflects, endorses, but also problematizes, dissident sexual behaviour" (Cook 35$){ }^{7}$ So Schulz provides an alternative to reading Dorian as a "gay novel" and urges us to "set the record queer" by allowing indeterminacy and ambiguity to remain. Rather than reading hints and symbols, as most do (including contemporary reviewers), Schulz makes a strong case for appreciating the ways the novel is intentionally queer. Essentially, when we recognize the novel's "wilful ambiguity," it does not matter whether Dorian has gay sex (11). Despite her insistence that it is a homosexual novel, even Sedgwick admits that "it is worth reemphasizing how thoroughly the elements of even this novel can be read doubly or equivocally" (Epistemology 165).

Indications of Dorian's indiscretions are intentionally indeterminate. While endnotes can tell us that, perhaps, the cab he takes after disposing of Basil's things is heading for the seedy

\footnotetext{
${ }^{7}$ Such a "secret, individualized map" can also be found in Teleny, and I discuss spaces where the gay counterpublic circulates in Chapter I.
} 
East End, all the novel tells us is that Dorian gives the cabman "an address" and the driver replies, "it is too far for me" before being bribed to go anyway (155). Similarly, the reason(s) Dorian's friendships with Alan Campbell and Adrian Singleton come to an end are never spoken. To help allow scenes like these to remain unspecified, I follow Schulz's use of "queer" in its most broad sense (generally supported by Butler and Barthes) that indicates the liminal, uncertain, unclassified and unclassifiable (fn. 10). Far beyond the sexuality (not) depicted in the novel, there are other elements that keep it queer. Rather than a normative couple, there is a love triangle, pointing to a queer focus on multiplicity rather than pairs (of romantic attachment, binaries, etc.). This multiplicity also manifests in "the passions that crowd the life of [Lord Henry's] protégé [which] include not only the intrigues with women that the novel mentions, and the entanglements with men that it almost does, but also 'mad hungers' for other items on a shopping list as long and miscellaneous as the book itself" (Nunokawa 82-3). Nunokawa's use of the word "miscellaneous" is telling: Dorian's obsessions with commodities are listed in the novel, but they indicate such a range and variety of his interests that his general collecting impulse is queer in its inability to be classified. When we consider his "shopping list" a passion of his life, we can see that it is queer in its infidelity to one type of item; his focus is on variety. "To define is to limit," says Lord Henry, the spokesman for much of the novel's queerness, and, "Knowledge would be fatal. It is the uncertainty that charms one. A mist makes things wonderful" $(165,173)$. Dorian's infatuation with Sibyl Vane perfectly suits both a queer reading and Lord Henry's quips: she is attractive to Dorian only while, and directly because, she is not a singular personality. Schulz says, "Dorian's desire for her is initiated exactly because of her ability to transform, to change, her effortless embodiment of endless potential modes of existence" (75). As an actress, Sibyl can be anything, and Dorian loves that "she is all the great 
heroines of the world in one. She is more than an individual" (48). Thus, Sibyl embodies the same variety that makes Dorian's collecting queer: she changes her identity with each new role. Moreover, Dorian is attracted to her "wandering through the forest of Arden, disguised as a pretty boy" in the character of Rosalind. In these cross-dressing scenes, Sibyl is Rosalind, and Rosalind is Ganymede - none can exist without the other, supporting layers of queer identity that only become more complex when one considers that the original Elizabethan Rosalind would have been played by a young man. Is Sibyl the female Rosalind? Or is she both the female Rosalind and the male Rosalind? Is she the echo of a boy actor, cross dressed as female Rosalind, but then "straight-dressed" as Ganymede? Or is it the other way around? The dizzying layers of performativity draw attention to the flexibility of a queer identity, which is what attracts Dorian. ${ }^{8}$ When her identity stabilizes into "just" Sibyl Vane, Dorian is crushed and loses interest. Indeed, the novel will not allow Sibyl to live as just herself, and she commits suicide.

By emphasizing the potential that queerness creates in the text of Dorian, Schulz indirectly echoes the time before sexuality was clearly defined and made a primary aspect of identity. Knowing that conceptions of sexuality were being formed and implemented at its time of writing makes it difficult to pin Dorian down as a "gay novel," since it goes against the very fluidity that creates potential for individual identity creation. To quote Lord Henry again, "to define is to limit" (165). Dorian is therefore an object of desire for men and women and

\footnotetext{
${ }^{8}$ Cook also points out that Sibyl's cross-dressed portrayal of Ganymede is "a performance which echoes that of Boulton and Park," famous "Mary Annes" or cross-dressing gay men (37).
} 
portrayed as masculine and feminine together; ${ }^{9}$ as I discuss at length below, he is many things in one body — but he is also not only limited to his body. His multiplicity extends beyond his material self to his portrait, adding to the variety of selves and potential identities.

\section{The "Subtle Magic" of the Portrait"}

Magical objects have been common tropes in folk and fairy tales for as long as such stories have existed. ${ }^{11}$ Amis et. al. call such magical items "talismanic object[s]," which they say can cause "time-slip" (133). ${ }^{12}$ In Victorian literature both before and after Dorian, the body or its reproduction is often the site of magic or transformation: Dr. Jekyll becomes Mr. Hyde, Dr. Frankenstein brings a monster to life, and Count Dracula feeds his own immortal body on the blood of others. Each of these has important similarities to the titular character: Mr. Hyde's evil impulses have increasing power over Dr. Jekyll's good nature, Dr. Frankenstein brings an empty body to life just as Dorian's portrait is magically vitalized, and Dracula gives up his soul to be immortal while Dorian wishes his away to remain beautiful. In the case of Dorian, the embodied magic links his real body with the representation of his body in the "talismanic object" of the portrait. As with some other stories of magical objects, Dorian provides an origin story for the

\footnotetext{
${ }^{9}$ See Schulz 21 for more on gender performativity.

${ }^{10}$ Dorian 19

11 The Magical Object is one of the primary features of folktale morphologies according to V. Propp. (Morphology of the Folktale 1968).

12 "Time-slip" will be discussed at greater length below in section IV.
} 
strange magic the picture possesses. Like Dr. Jekyll's potion and Dr. Frankenstein's electricity, Basil, Lord Henry, and Dorian provide the catalyst for enchanting the portrait.

As the painter of the portrait, Basil is the literal creator of the magical object, but his adoration of Dorian also creates a sort of plausibility for the potential of the portrait. Basil says several times that he has "put too much of [himself] into it [the portrait]," and further, that he has put into the painting "the secret of [his] own soul" $(6,8)$. Basil primes the canvas, so to speak, and without his "curious artistic idolatry" (but "it was really love"), the portrait would be mere paint $(13,102)$. The "subtle influence" Dorian has on Basil and the 'intense interest' he holds for Lord Henry each contributes to their ability to play a role in Dorian's magical wish, rationalizing the magical element of the story by setting it up as a result of these relationships $(13,20)$.

Symbolically, Basil prepares the painting while Lord Henry prepares the man-a hint that the two will soon be united. Though Lord Henry says later that "art has no influence upon action," the magic and action of the story obviously revolve around and stem from these initial relationships with art. Lord Henry begins talking to Dorian while he models for the painter about living "fully and completely," including one of his more famous aphorisms, "the only way to get rid of a temptation is to yield to it" (19). The effect that this philosophy has on Dorian is immediate: the words "touched some secret chord that had never been touched before, but that he felt was now vibrating and throbbing to curious pulses" (19). In addition to the sexual overtones, the "subtle magic" that Dorian experiences is the beginning of Lord Henry's dominance over him, and it leads him to the desire to remain forever young (19).

To highlight the magical atmosphere of the studio, when Basil announces that the painting is finished, Dorian "start[s], as if awakened from some dream" (24). Dreamscapes and 
wonderlands are precisely the places we expect portraits to come alive. The magic of the portrait is initiated by a wish that the portrait ages instead of his body, which is repeated by Dorian twice, like a spell. Amis says that this feature of time magic, "flirt[ing] with the collapse of time" by making a "rash wish" to escape natural aging, "threatens to obliterate the self" $(132,137)$. The key word here is "threatens"- - showing that while departure from linear time endangers the subject, it is only "hazardous" or "menac[ing]" (132). This balancing act, a "flirt" without commitment, creates a queer subject position between existence and "obliteration," danger but not necessarily damage, suspension between safety and harm where we cannot know whether the "threat" to the self will manifest or remain mere "menace." Moreover, Dorian's body and soul seem to be separated, simultaneously emphasizing the separation of the material from the spiritual realm and their codependence, and existing in a queer, undefined state that lends Dorian's identity flexibility and unfixedness.

When Dorian discovers that his wish has been granted (after rejecting Sibyl), he suspects there is an explanation for the painting's changed appearance. The narrator speaks Dorian's mind, saying, "he found himself at first gazing at the portrait with a feeling of almost scientific interest. [...] Was there some subtle affinity between the chemical atoms, that shaped themselves into form and colour on the canvas, and the soul that was within him?" (82). The "scientific interest" Dorian shows in the supernaturally-changed portrait echoes a movement during the late Victorian age to approach spirituality as a science. The Society for Psychical Research (SPR) and psychical researchers at large approached the supernatural with a critical, scientific eye and looked at the metaphysical as an area of study. Thus, Dorian's hypothesizing about "chemical atoms" is in line with the contemporary research-inclined branch of alternative spiritual expression. Later, he meditates on his theory: "Might there not be some curious scientific reason 
for it all? If thought could exercise an influence upon a living organism, might not thought exercise an influence upon dead and inorganic things? Nay, without thought or conscious desire, might not things external to ourselves vibrate in unison with our moods and passions, atom calling to atom in secret love or strange affinity?" (91). This beautiful passage illustrates the main goal of most varieties of Spiritualism, to find the "common denominators of the universe [...] whether one stressed the links between heat, electricity, magnetism, and light, or looked for connections between mind, spirit, and matter" (Oppenheim 396). Dorian dabbles in other types of spirituality, too, including Catholicism, Darwinism, and "Mysticism, with its marvellous power of making common things strange to us" (112-3). References to actual contemporary spiritual movements and societies add plausibility to the novel's fantastic, magical portrait. Each of Dorian's spiritual interests serves to amplify his queer position as well, since his unwillingness to commit to any reinforces his multiplicity.

Beyond these hints of realistic contemporary psychical research and spirituality, Dorian's portrait is clearly supernatural, whether it is considered the "most magical of mirrors" or "the face of [his] soul" $(91,132)$. Dorian's wish says that if the portrait would age instead of his body, he would "give [his] soul for that!", implying that his soul would be taken (by the devil?) as payment for the exchange and removed by a third party from the equation (25). However, later textual evidence indicates (and almost all scholarship about the novel operates under the understanding) that Dorian has given his soul to the painting and that the aging and sin-induced ugliness the painting eventually portrays is the physical expression of Dorian's metaphysical self. While Spiritualists of many varieties focused on "the way that the divide between visible and invisible was traversed," Wilde binds the invisible soul to the visible material painting, illustrating instead the "power that the spirit realm holds in shaping the real" by showing us the 
changes in a soul reflected on the material canvas (Willburn 1, 70). Rather than "traversing" planes of existence or focusing on their separation and how to navigate either, Dorian unites the two inextricably. By un-doing the binary and combining seeming opposites, the novel emphasizes its queerness: Dorian and his painting are neither two subjects nor truly one, and the painting is neither solely material object nor pure spirit.

Just after the transfer of Dorian's soul to the canvas, Basil sees how distressed Dorian is at the thought of his portrait remaining beautiful long after his looks have faded, and the artist offers to "destroy" his work (26). Panicked, and perhaps subconsciously already aware that it contains his soul, Dorian cries, “Don't, Basil, don't! [...] It would be murder!” (26). He explains his outburst by saying the painting "is part of [himself]," and later, Basil calls it "the real Dorian" $(27,28)$. But the soul is not allowed to become truly mundane even though it is held in a commonplace material object: throughout the novel, Dorian's reactions to the picture maintain its supernatural essence. When he first discovers a change in the painting, he calls it "impossible," "monstrous," and "secret"; the portrait's changes are "phantoms" left by Sibyl's bad performance, or "the visible emblem of conscience," and the next day as he thinks about the changed portrait, "there was the unreality of a dream about it" $(78,79,81)$. When Dorian prepares to have the painting moved to his old school room, he reiterates its mystical powers, saying that it would "never die," although it would be corrupted, "the thing would still live on. It would be always alive" (101). And, later, when Dorian divulges the secret to Basil, the entire conversation about the revelation centers on the "soul": "I shall show you my soul," says Dorian, and then, "So you think that it is only God who sees the soul, Basil? Draw that curtain back, and you will see mine" $(129,131)$. Thus, while the novel experiments with uniting the supernatural and the material worlds that held so much interest for the Spiritualists, the way Dorian treats his 
portrait actually maintains the separation of the spheres and draws attention to the fact that his soul is indeed separated from his body. This, too, emphasizes its queer nature, because while the portrait undoes the binary of material and spiritual by placing a soul in an object, it also refuses to fully unite them. Instead, they remain unfixed, undefined. The portrait represents and contains the magic of the novel, though it avoids domesticating such mysteries.

\section{Time Magic}

By the end of his story, the connection between the soul and the material painting have taken their toll on Dorian. In his final moments, he emphasizes the power the portrait holds, once again calling it his "conscience" and a "monstrous soul-life" (187). He thinks, holding a knife, "as it had killed the painter, so it would kill the painter's work, and all that that meant. It would kill the past, and when that was dead he would be free" (187). Dorian's thought process at this moment represents another type of magic the portrait initiates, the magic of interrupted linear time. To kill Basil and the portrait with the same knife creates a circular pattern of events, and to "kill the past" is to live in a perpetual present. The novel's basic device that Dorian will not age is akin to suspending him in time. Though there are episodes of activity and interaction, and though years pass in the novel, Dorian himself is in a continuous present that never progresses forward into the future. His body remains roughly twenty years old, always the same, which is more and more distanced from the "real time" of his surroundings - farther and farther in the past. This chronological contradiction leads to "queer time" (perpetual focus on the present moment) and time-based magic outside chrononormativity.

The seemingly contradictory temporal schemes of the perpetual present (stagnant) and circular time (always revolving) are actually somewhat complimentary in practice: Dorian's 
beauty denies his history (the physical expressions of the sins he has committed, according to the magical logic of the novel) while also denying his future (the impact old age would have on his good looks); similarly, the circular time of the novel is expressed by repeatedly revisiting certain themes, phrases, and concepts that make up whichever moment is present without learning from the past or looking forward to the future. In the passage quoted above, Dorian uses the same knife to kill Basil and himself. Sibyl Vane commits suicide, and eventually Dorian dies at his own hand, too. The first page of the novel indicates Basil's disappearance, and then more than one hundred pages later, he actually 'disappears.' Lord Henry introduces Dorian to his mantra, "Nothing can cure the soul but the senses, just as nothing can cure the senses but the soul" early in the story, and Dorian repeats it twice on his trip to the opium den near the end of the novel $(21,155) .{ }^{13} \mathrm{He}$ repeats the adage to himself in a different form that highlights its repetition just before arriving at the East End: "passion makes one think in a circle [... the] lips of Dorian Gray shaped and reshaped those subtle words that dealt with soul and sense" (156). Moreover, the pairing of the "senses" and the "soul" also appears in Chapter XI's discussion of spiritual philosophies. The location of the picture throughout the novel is also an indicator of circular time. The school room where Dorian was educated as a child becomes the site of his visual education as the portrait instructs him about the impact his actions have on his soul.

Though these examples seem to indicate circular time by allowing the same actions and words to resurface multiple times, they also indicate stagnation because the novel cannot move

${ }^{13}$ An endnote indicates that this sentiment is borrowed from Walter Pater's Marius the Epicurean, as are many of the aesthetics of the novel. 
past them to new actions and words. ${ }^{14}$ But the perpetual present-queer time-does not mean paralysis. Indeed, it can be a time of extreme activity, such as we see with Dorian's attendance at parties and concerts, as well as his travels to the East End for sex and drugs. "For queers, the separation between youth and adulthood quite simply does not hold, and queer adolescence can extend far beyond one's twenties," Halberstam explains, and so “queer urbanites, lacking the pacing and schedules that inhere to family life and reproduction, might visit clubs and participate in sex cultures well into their forties or fifties on a regular basis" (“Queer Temporality" 174). At age forty, Dorian acts the same way as he did when he was twenty, and his unchanged appearance merely emphasizes his continued adolescence. This kind of queer time "challenges the conventional binary formulation of a life narrative divided by a clear break between youth and adulthood," undoing the differences between the two stages and leaving only a queer present state (Halberstam, “Queer Temporality” 153). Dorian’s perpetual adolescence illustrates this central concept of queer time, and his life's goal to seek out pleasure suits Halberstam's assertion that "the constantly diminishing future creates a new emphasis on the here, the present, the now, and while the threat of no future hovers overhead like a storm cloud, the urgency of being also expands the potential of the moment and [...] squeezes new possibilities out of the time at hand" (“Queer Temporality" 2). The unlimited "potential of the moment" is precisely what Dorian seeks to explore; the portrait allows him to maintain his youthful looks and his adolescent desires for new and exciting experiences into his forties.

\footnotetext{
14 This repetition could contribute to Dorian's ennui, which prompts him to seek out new and exciting hobbies and collectables - but when everything is new and exciting, nothing is, and the cycle continues.
} 
In addition to the queer time of his youthful looks and actions, Dorian has episodes of collapsed time, such as when he watches Sibyl perform badly: "During the three terrible hours that the play had lasted, he had lived centuries of pain, æon upon æon of torture” (79). Lord Henry consoles him after Sibyl's death by encouraging Dorian to continue to live only in the present, saying, "the one charm of the past is that it is the past" (87). Dorian obediently repeats the advice to Basil, saying, "what is done is done. What is past is past," but Basil interjects, "you call yesterday the past?" and Dorian emphasizes the message: "What has the actual lapse of time got to do with it?" (93). The form of the novel itself collapses twenty years into sporadic episodes each portrayed as present, like queer time. Dorian's queerness allows him to operate "outside the frameworks of conflict or mandatory continuity," emphasizing his fluid identity (Halberstam, "Queer Temporality" 185). Conflict and continuity both inherently use the logic of cause and effect, but in queer time the binary is broken into a string of causes with no outcomes, as we can see from Dorian's denial of the past quoted above. His wish that the portrait age instead of his body thus also expresses his desire to operate in queer time, separating his actions from their physical consequences. Freedom from consequence is, therefore, another expression of queer time, as it divorces causes from their effects.

Normative understandings of cause and effect lead to linear time, wherein one could predict outcomes (effects) based on inputs (causes). But in circular time, the future is still predictable, since we can understand that things that have happened before will happen again. This differs from cause and effect because it presents a string of causes, repeated. Furthermore, because the portrait creates a self-fulfilling cycle of queer activity for Dorian, the future is inevitable; the "trajectory" is in fact compressed into a queer present moment, as I will explain below. The first type of time magic based on circular repetition is prescience, and the second, 
based on inevitability, is fate. ${ }^{15}$ Dorian provides evidence of the presence of prescience and inevitability again and again. Basil describes seeing Dorian for the first time: "I had a strange feeling the Fate had in store for me exquisite joys and exquisite sorrows," and shortly thereafter, "He, too, felt that we were destined to know each other" $(9,10$, emphasis mine). Dorian says of his portrait, "It will mock me someday—mock me horribly!" and he is right, though not in the sense he means (26). When Basil offers to destroy it, as quoted above, Dorian can somehow tell that "it would be murder," and he is certainly right again—when he stabs the canvas at the end, he murders himself (26). Later, Dorian calls the portrait itself "fatal" and thinks that there is "something tragic in a friendship" like Basil's—as tragic as murder (100). In each of these examples, foreshadowing can be considered prescience; after all, the basic literary technique allows the audience, if not the characters, to predict the future of the narrative. Circularity, the perpetual present, and inevitability all play a significant role in creating Dorian's life outside chrononormativity.

These several types of time magic — queer time, which focuses on a suspended present, circularity, which reiterates actions and words without moving forward, and prescience, which can tell what will come next based on what has already happened in cyclical time—all work together to emphasize Dorian's queer identity. Additionally, Dorian experiences "time-slip"

${ }^{15}$ Both of these manipulations of time go against what some contemporary Anti-Christian Spiritualists believed, since they diminish the role of individual responsibility and agency. This sect was called "Anti-Christian" because, along these lines, they heartily denounced predestination. This logic is still based on the cause and effect binary of linear time, though, since it relies on the notion that actions necessarily have consequences. 
through possession, addressed at length below, which ties his identity to an even broader sense of time and time magic. The novel presents "ways of living aslant to dominant forms of objectchoice, coupledom, family, marriage, sociability, and self-presentation" (Freeman xv), ${ }^{16}$ and allows us to "detach queerness from sexual identity" by realizing that it is not only Dorian's unspecified sexual preferences that make him queer, but also his extended adolescence (Halberstam, "Queer Temporality" 1). The flexibility of Dorian's identity allows him to circulate both within and outside normativity. The magic of his portrait, created by his wish to experience action without consequence, is both enabled by and encourages his queer activity, putting him outside linear time and allowing his identity to become fluid and multiplicitous.

\section{Dorian's Identity: Picture and Possession}

It is fitting that the title of Wilde's novel is The Picture of Dorian Gray and not just Dorian Gray - though I refer to it throughout as Dorian, the character is almost entirely defined by his portrait and its magic. This focus may be a function of how little we know of Dorian before the portrait is painted, but the text indicates that after the picture is finished, Dorian loses agency and individuality. Dorian, then, is formed and defined by external factors: his identity is formed by the portrait's power, which sets him on an inevitable path of compressed present moments and the influence of others. After the magical wish comes true, his soul is external to himself and the picture seems to have a mind of its own. This leaves Dorian without his own

\footnotetext{
${ }^{16}$ Freeman calls these "teleological schemes" "chronobiopolitics," a sense of larger temporal belonging to state-implemented apparatuses which Dorian rejects (4).
} 
identity, but his life is filled with the influence of other people and things, highlighting his queer position as unfixed and indeterminate, and made possible by the portrait.

The inevitability discussed above in terms of its relation to time is also something that disrupts identity formation because self-formed identity relies on free will or choice. But Dorian is in a fateful feedback loop: in addition to making his lifestyle possible, I argue that the painting creates a self-fulfilling path Dorian is powerless to resist. His complete submission to the domination of the picture is shocking at times; after wondering whether Basil's love "could have saved him" from his fate, he ruminates, "but the future was inevitable. There were passions in him that would find their terrible outlet, dreams that would make the shadow of their evil real" (102). Indeed, the very thought that Basil holds the power to redirect his fate means Dorian does not believe he has the power to do it himself. Though the "passions" are "in him," Dorian feels powerless to resist their desires and so they are not internalized so much as personified, given a life of their own which controls him, all made possible by the portrait's magic. At two critical points, Dorian even directly identifies the painting as the controlling force of his life and choices: when he gets the urge to kill Basil, the narrator says Dorian "glanced at the picture, and suddenly an uncontrollable feeling of hatred for Basil Hallward came over him, as though it had been suggested to him by the image on the canvas" (133). Later, when he takes his own life, Dorian is troubled by the "living death" his soul has been put through, and concludes, "It was the portrait that had done everything" (185).

\section{Emptying Dorian}

To make room for the insertion of multiple foreign identities that supplant his own singular subjectivity, Dorian continually surrenders opportunities to make choices or chooses to 
accept alternative identities. "Dorian is himself both bifurcated and hollowed out," says Shelton Waldrep in The Aesthetics of Self-Invention; he is "neither wholly human nor ever completely more than the signifier of a split in the concept of identity as it existed at the time of the novel's conception” (19). Dorian's 'hollowness' allows him to take on disguises — both literal costumes and figurative ones, seen in his ability to take on new names ("Prince Charming") and new social personae (allowing him to navigate both the symbolic West End and East End). As Waldrep points out, "Dorian's own face is now a mask," since it is magically unaffected by the life 'underneath' on the painting (19). Dorian's body covers a void, he is hollow and empty, unwilling to actively make choices or take responsibility for things that happen to him.

Dorian also protests when anyone else tries to fix his identity or force him to claim it (i.e. to take off the mask): he uses his youthful face to deny being Prince Charming when confronted by James Vane, and when Lord Henry calls him Prince Charming shortly thereafter, he cries, "Ah! don't remind me of that" (165). In his last meeting with him, Basil tries to separate Dorian's real identity from his various masks by confronting him about circulating rumors. Dorian's immediate reaction betrays his ennui, but is also perhaps an act to divert Basil's line of inquiry: "I am tired of myself to-night. I should like to be somebody else" (126). Dorian pointedly refuses to own (or form) his selfhood, stubbornly remaining queer, a position enabled by the magic of the portrait. He also refuses to take on the identity of the antagonist when he forces Alan Campbell to dispose of Basil's body, saying "I can't help myself," "I am forced," and "I have no option" (142). And, about threatening Campbell with blackmail, Dorian says, "you leave me no alternative" and "I must send it [the letter]" (144). The intentional indeterminacy of Dorian's identity allows him to circulate as others or without agency and increasingly emboldens his non-normative actions. 
"Somebody else" is certainly what Dorian is and becomes throughout the novel. His brief but passionate romance with Sibyl helps illustrate his own identity by offering a parallel in the actress. Dorian describes her as "more than an individual," creating for her an aggregate identity which includes her characters as Dorian's identity includes his portrait, his disguises, and the influence of others. Indeed, her artistic ability is described in terms of projecting her own soul into others and Basil concedes, "If this girl can give a soul to those who have lived without one, if she can create [a] sense of beauty in people [...], she is worthy of all your adoration" (70-1, emphasis mine). Sibyl's possessive ability (translated through her acting) makes her a parallel to Dorian but also a complementary force that could fill his voided identity. Basil says, "without her you would have been incomplete," highlighting both her ability to 'complete' Dorian and Dorian's own emptiness (71). When she disappoints him and becomes a singular identity, no longer her characters but only herself, he rejects her by saying "without your art you are nothing," and later says to Lord Henry that "she never really lived," but rather that she is "less real" than the characters she played $(75,89)$. Of course, without Dorian's art—his portrait—perhaps he, too, would be "nothing" (socially), and he "never really live[s]" because his soul, arguably the part that is 'more real' than his material body, is stored in his old school room. The narrator explains Dorian's modus operandi: "Life itself [is] the first, the greatest, of the arts" (110); we are to understand Dorian's identity is just as fluid and artificial as Sibyl's "art." While Sibyl has the stage, the malleability of Dorian's identity and its refusal to be fixed are directly caused by the magic of his portrait.

The picture facilitates Dorian's queered refusal of self-definition: his identity defies categorization. The mystical power of the painting allows Dorian's queer sexuality to emerge, further complicating his identity; in fact, the picture encourages increasingly errant behavior in 
Dorian because he discovers his ability to refuse agency and avoid consequence using his youthful beauty, thereby dodging anything that would discourage him. ${ }^{17}$ Evidence for this evasion appears throughout the novel: Basil, James Vane, and Lord Henry each say they do not believe he is capable of doing the bad things they hear he has done because "sin is a thing that writes itself across a man's face" (126). Dorian absolves himself of his sins just as easily; he moves on from his role in Sibyl's suicide in less than a day and, despite his moments of regret or debate, continues visiting opium dens quite late in the novel. He admits that Sibyl or Basil could "keep [him] straight" (85), but is unable to act by himself on his desire to reform after her death:

He felt that the time had really come for making his choice. Or had his choice already been made? Yes, life had decided that for him-life, and his own infinite curiosity about life. Eternal youth, infinite passion, pleasures subtle and sweet, wild joys and wilder sins - he was to have all these things. The portrait was to bear the burden of his shame: that was all. (90)

He does eventually "spare" Hetty Murton at the end-which, of course, he admits to himself is a selfish and pleasurable act after Lord Henry's interpretation (177). In each case, the magic of the portrait or the influence of its magic forms Dorian's responses to and interactions with the world, thereby shaping his (lack of) identity. The novel even gives us hints as to what the alternatives are: without a magical portrait granting him youthful beauty, and a flexible, queer identity, Dorian would become an exiled opium addict like Adrian Singleton, or a shamed, blackmailed,

${ }^{17}$ For example, when Dorian is preparing to destroy his portrait, the action is projected onto the knife rather than Dorian: "as it had killed the painter, so it would kill the painter's work" (187). 
and ultimately dead-by-suicide Alan Campbell. Basil, the closest the novel gets to an openly gay character, is murdered by the man he loves.

\section{Filling Dorian}

The portrait gives Dorian the freedom and the ability to empty his identity, making it unfixed and queer, refusing definition. "To live as Dorian lives—at least for a time—is to exist outside the laws of nature, beyond the control of realism," and, I would add, uncontrolled by heteronormative social pressures (Waldrep 20). The magic that leads him to his fate creates queered time and enables or encourages his queer sexuality: Dorian's identity becomes a constellation of things that control him, promiscuous and ever-changing. Some of the things that possess Dorian are named, like his portrait and Lord Henry's influence, or his collections of commodities, but many of his sins remain unspecified, further queering what he fills his life with by sustaining the possibility for anything. As argued above, Dorian actively empties himself to allow multiple identities to take hold of him, and indeed the fact that his soul resides in the portrait helps ensure he is truly a tabula rasa, ready to be possessed. This possession creates another connection to contemporary fascination with mysticism, and proves Dorian is an excellent medium. According to some accounts included in Sarah A. Willburn's Possessed Victorians, women were more inclined to be, and were more successful at being, mediums who could summon and be possessed by others (65). In this way, Dorian's abilities as a medium feminize him, and since he is possessed primarily by Lord Henry, his queer sexuality is highlighted at the same time as his spiritual power. This combination is what truly forms his identity: Dorian's mystical abilities allow his sexuality to be queer, and his queer sexuality enables his participation in spiritualism. The circularity inherent in this relationship to his 
portrait reinforces his inability to be classified: there is no cause and effect, no binary of youth and age, male and female, spiritual and physical. Instead, Dorian occupies the liminal spaces between and outside each category, the combination of magic and sexuality making it possible to remain unfixed.

Basil is the one who creates the potential for the portrait's magic by imbuing it with his own feelings for Dorian, setting the stage for the supernatural transferal of his soul. Basil's passionate adoration works as the primer for Dorian's soul to transfer to the portrait. But before we learn that Dorian's soul has possessed the art, Basil admits that, in a sense, Dorian has also possessed him in spiritual and sexual ways. His "worship" of Dorian is both religious (as an aesthetic object) and erotic (99). ${ }^{18}$ He claims that "as long as [he] live[s], the personality of Dorian Gray will dominate [him]," indicating that Basil is as ready a medium for possession as Dorian himself (14). Basil's complete surrender to Dorian's influence also indicates that until the transfer of his soul to the painting, Dorian was perhaps able to project his own self into others-Basil confesses to him, "from the moment I met you [...], I was dominated, soul, brain, and power by you" (97). The power that Dorian has over Basil's "soul" can be read in two complementary ways that, together, solidify the union of sexuality and spirituality in identity formation: Basil is "dominated" by irresistible sexual desire for him, and Dorian simultaneously possesses the artist, who, while imbued with two spiritual natures within his one body, expresses

\footnotetext{
${ }^{18}$ Basil also gives us the closest thing to normative spirituality in the novel, calling Dorian's wish a "prayer" and urging him to repent and pray that his soul be restored to his body (133).
} 
the possession via the creation of art. Indeed, drawing while possessed was a very common expression of late-Victorian mystics. ${ }^{19}$

Lord Henry's possessive influence works in a similar way, though after Dorian's soul is transferred to his portrait he does not contain a spirit of his own. In particular moments, rather than possessing multiple individuals in one body (as Basil does), Dorian's body houses a split subjectivity shared between two bodies: his and Lord Henry's, where the personality originates. This possibility is discussed by Willburn, who says that "aggregate characterization" reflects the "feature of one body not equaling one person," meaning that it was possible to find "plural souls in one body" or, by contrast, that "some characters [...] share one soul between them" (41). While the novel calls Lord Henry's possession of Dorian "influence," the language that describes their relationship clearly illustrates the same "dominance" that Basil experiences. Nunokawa explains, "Lord Henry delighting behind the scenes at his knack for imposing the temperament that he claims only to observe, to form the subject whose self-determination is all he claims to care about, confirms a most paranoid vision of power, and a most appreciative one, as well" (36, emphasis mine). The "power" Lord Henry has over Dorian is, as discussed above, arguably what sets the magic of the portrait in motion, since it is Lord Henry's conversation that makes Dorian realize he wishes his portrait would age instead of his body. Combined with the inevitability or fate that the picture seems to cause, Lord Henry's influence and Dorian's wish create a domino effect that leaves Dorian a puppet or, in spiritual terms, a hollow medium ripe for possession.

As with Basil, Lord Henry's “influence” can be read as sexual as well as spiritual, once again tying the two identity-forming factors together in the main characters of the novel: "the

\footnotetext{
${ }^{19}$ See Willburn for facsimiles of possessed artwork and a discussion of the trend.
} 
more Lord Henry encourages Dorian Gray to explore how various art forms can arouse exquisite emotions, the more the young man's passions are attracted to sensations and ideas whose pleasures are taboo" (Bristow xv). The younger man is susceptible to Lord Henry's 'encouragement' because Dorian desires him sexually, and his witty aphorisms seem to affirm the viability of aberrant sexuality despite its being "taboo." Indeed, the chorus of the book, "nothing can cure the soul but the senses, just as nothing can cure the senses but the soul" is one Dorian seriously puts into practice (21). Dorian meditates on the sentiment while on his way to an opium den, where it appears twice in half a page: "“To cure the soul by means of the senses, and the senses by means of the soul.' Yes, that was the secret. He had often tried it, and would try it again now" (155). Lord Henry's principle, like the portrait and my theory of identity formation based on sex and spirituality, unites the metaphysical and the body.

Dorian's pursuit of sexual pleasures based on Lord Henry's quip aligns with a spiritual practice called Spiritual Darwinism, which places emphasis on the embodied experiences that can unite individuals physically and bring them to spiritual evolution. In this type of spiritualism, "nature cannot be understood outside of the spiritual, and it is an experimental playground that promotes not the survival of the fittest but the survival of the most spiritually sexual" (Willburn 72). Entirely in line with Lord Henry's theory, Spiritual Darwinism proposes that "the only way to salvation and spiritual enlightenment is through refined sex acts in which spiritual (rather than material) fluid is exchanged," and "the mind's advancement relies on the body having sex" (Willburn 73). Dorian's quest for physical pleasure to 'cure the soul' follows leading Spiritual Darwinist Lois Waisbrooker's theory which seeks to undo the mind-body 
binary in favor of unity, but Lord Henry's mantra maintains their separation by setting up the dichotomy in its vice-versa formulation. ${ }^{20}$

Curing the soul and the senses using the senses and the soul is the book's central aesthetic message, combining sexuality and spirituality_but it's also the prime example of Lord Henry's possession of Dorian. When he flippantly includes the aphorism in a speech in Basil's studio at the beginning of the novel, it takes hold of Dorian and steers his actions for the rest of his life. In fact, Lord Henry says just a few pages earlier, "to influence a person is to give him one's own soul. [...] He becomes an echo of someone else's music" (18). After his meeting with Lord Henry, very similar to the first meeting Basil has with Dorian, the young man is entirely "dominated" by him: beginning with their exit from the studio and throughout the novel, he obeys Lord Henry's commands: "I must go" and "I feel I must come with you," he says $(28,40)$. Moreover, Lord Henry knows he has this power, saying, "all through your life you will tell me everything you do," as if commanding a hypnotized patient, which Dorian readily agrees to: "I believe it is true. I cannot help telling you things. You have a curious influence over me," he says (46). Later, Dorian does tell him his darkest secret: that he murdered Basil.

Lord Henry's theories of influence and Dorian's own lack of agency surface again and again in the novel. Though Lord Henry claims to be interested in merely observing the beautiful youth, the narrator reveals his thoughts:

${ }^{20}$ Lois Waisbrooker wrote on spirituality and social topics beginning in the $1860 \mathrm{~s}$, so it is possible Wilde read her "widely published" work, but her manifesto on sex and spirituality, The Fountain of Life, or the Threefold Power of Sex was not published until 1893, three years after the first appearance of Dorian (Willburn 71-2). 
Talking to [Dorian] was like playing upon an exquisite violin. ${ }^{21}$ He answered to every touch and thrill of the bow.... There was something terribly enthralling in the exercise of influence. [...] To project one's soul into some gracious form, and let it tarry there for a moment; to hear one's own intellectual views echoed back to one with all the added music of passion and youth; to convey one's temperament into another as though it were a subtle fluid or a strange perfume: there was a real joy in that. (33)

Playing another as an instrument, projecting a soul into another form, transferring a temperament - the language of spiritual possession is clear. Even when Dorian is in love with Sibyl, Lord Henry sees himself in him, musing, "to a large extent the lad was his own [Lord Henry's] creation" (51). Dorian willingly takes on the spirit of Lord Henry, just as Basil accepts being possessed by Dorian. After repeating one of Lord Henry's witticisms back to him, Dorian says, "I am putting it into practice, as I do everything you say," and it is especially noteworthy that the first thing Dorian rejects when he tries to reform is Lord Henry's "poisonous theories" $(42,79)$. Of course, he sees his friend almost immediately after making the resolution and things quickly go back to normal with Dorian securely possessed by the older man. In the last portrayed interaction that they have, Lord Henry says, "You and I are what we are, and will be

${ }^{21}$ Sibyl Vane's ability to possess others is also compared to playing an instrument: "She makes them as responsive as a violin. She spiritualizes them, and one feels that they are of the same flesh and blood as one's self" (70). This passage also emphasizes promiscuous unity in the mixing of "flesh and blood" of others and "one's self," simultaneously embodied and "spiritualized." 
what we will be," trying to soothe Dorian's angst over the life he has lead (183). But what is noteworthy is the pairing of "You and I," which then becomes one word, "we"; Lord Henry sees himself so much a part of Dorian that when consoling the other man he includes himself and unites their pronouns.

Lord Henry is not the only one to possess Dorian. Sibyl, perhaps, 'completes' him as quoted above, and he claims that he is the aggregate product of his own ancestry and many historical and even literary figures. The narrator elaborates on Dorian's thoughts, saying, "to him, man was a being with myriad lives and myriad sensations, a complex multiform creature that bore within itself strange legacies of thought and passion, and whose very flesh was tainted with the monstrous maladies of the dead" (121, emphasis mine). Here, again, we can see the emphasis on embodied multiplicity: Dorian contains an ever-changing constellation of individuals within his single physical form. The most notable of Classical figures Dorian is compared to is Antinoüs, the famous lover of the emperor Hadrian (12, 18 and 98), and Narcissus, in love with his own reflection $(6,98)$. The comparison to Antinoüs is a transparent reference to pederasty and same-sex love, while the reference to Narcissus symbolizes love of the self-same, which can be interpreted as love of the same sex. But he is also called Adonis (6, 98), "Dryad-like" (34), and Paris (98).

Willburn helps conceptualize how such multiplicity works using the word "promiscuous": "promiscuity, denotatively speaking, the mixing of the unlike, such as entranced conversations between the living and the dead, or a body mingling with diverse spirits can be reconsidered as a force that enables a different type of social and self-organization for the possessed" (117). The "mixing of the unlike," the most general definition of promiscuity, helps move beyond the modern connotations of many sexual partners, but the dual use of the word 
helps illuminate Dorian's domination by others: Lord Henry's possession is certainly sexual, and many of Dorian's historical predecessors also have same-sex desire or aberrant sexualities, like his ancestors "the lover of Giovanna of Naples" who "bequeathed him [...] sin and shame," or Lady Elizabeth Devereux, of whom "strange stories were told about her lovers" (121-2). The narrator explains, "the whole of history was merely the record of his own life [...] their lives had been his own" (122). Dorian, then, is possessed by multitudes and contains parts of each of them - moreover, he believes in their power and influence. Promiscuity, like Spiritual Darwinism, encourages the creation of such mingling, "interruptive archaisms," as Freeman calls them, between individuals even across time- - whether sexual or spiritual or both (7). Such "time-slippage" emphasizes queer variety and spiritual promiscuity tied to possessive magic, as Dorian becomes multiplicitous in his incorporation of other subjectivities within his singular body, enabled by his portrait's containment of his soul.

Dorian's aggregate identity stretches across time by including historical figures, Classical characters, and his own ancestors. The coexistence of the chronologically-distant possessive identities adds to the sense of time-magic discussed above by further collapsing linear time into Dorian's singular present. It also creates circularity by allowing individuals from the past to resurface in the present by using Dorian's body. Willburn says that this "model of identity as synchronic complicity" is based on "shared time and space" (41). Furthermore, such "synchronic complicity" "make[s] a single identity impossible and replace[s] it with a plural one, [and] also turned a person from an 'is' to a 'does"' (Willburn 88). So rather than being a unified subject, Dorian becomes only actions guided by these others who possess him across time. Queer time supports the idea of fractured self as well; as Halberstam asserts, "the notion of a body-centered identity gives way to a model that locates the sexual subjectivities within and 
between embodiment, place, and practice" ("Queer Temporality" 5). Changing "from an "is' to a 'does"” (Willburn), with this focus on "practice" (Halberstam), is especially noteworthy in Dorian: as mentioned above in the context of queer time, the story unfolds as a series of moments, each shown as the present. Coherent, fixed identity across time creates a sense of self that allows one "to be" or-in other words—-makes a person an "is." Without such unity over time, a person merely "does," as is the case with Dorian. He "does" a lot of things: collecting, travelling, experimenting, and socializing. But his actions are not his own, are not cumulative, and reflect a queer focus on only the present and plural, only the 'doing,' not the 'being.' This "synchronic complicity" of possession across time is made possible by Dorian's hollow identity and the magic of the portrait.

\section{Conclusion}

Dorian's death reveals his intense struggle with morality and guilt, though ironically he is not afraid of being exposed as a sinner to the world, since he seems to believe that destroying the portrait will transfer his ugly soul back to his pristine body (or at the very least he does not care if it will). His remorse is finally strong enough to drive him into action, and attempting to destroy the portrait is the first thing that Dorian seems to choose for himself. But after a lifetime of being possessed and surrendering agency, he can only choose to die, not to live. Sibyl's death provides a parallel, since both she and Dorian end their own lives. Dorian says of Sibyl, "The moment she touched actual life, she marred it, and it marred her, and so she passed away" (89). Dorian, too, is shielded from experiencing "actual life" by surrendering his identity to the possession of others. When he tries to shake off their hold-especially the influence of the portrait itself-he is "marred" and does not survive. 
Dorian's decision emphasizes his queer time, since destroying the portrait means literally destroying his reproduction, and he is unable to reinsert himself in chrononormativity successfully. But his death brings an end to his connections to the things and people that had possessed him, thus also ending his queer time and time magic. When Dorian resolves to destroy the painting, he thinks that the action "would kill the past, and when that was dead he would be free" (187). "Free" from possession, "free" from influence; "the past" is what he feels threatened by and plans to end. His fate, on the other hand, is undeniable: indeed, just before his unwitting suicide, he breaks a mirror - the epitome of bad luck and a foreshadowing of what he is about to do: ruin his own image. Dorian's decision to destroy the portrait that possesses him is thus entirely incompatible with queer time and time magic, which emphasizes his inability to live without these mystical powers of influence. Instead, his decision indicates that Dorian has discovered personal responsibility, and his acceptance of cause and effect attempts to reinsert him into linear time and normativity. His death immediately after this discovery, though, forecloses the possibility of true free will by indicating that Dorian simply cannot live without his queer flexibility and multiplicitous identity.

Amis et. al. astutely observe, "while [...] time-slip fantas[ies] may not tell the reader much about real history, they do reveal quite a lot about the attractions of alternative outcomes, exonerating determinist causes, and supernatural agents" (144). Although Dorian does "reveal" the historical dangers of a queer lifestyle at the fin de siécle, the novel also shows us the "alternative outcomes" of potentially freeing experiences that come with opening the queer self to incorporating multiplicity and refusing definition. Dorian's potential lies in his ability to interact with in "supernatural agents," using his queer liminality to both empty himself of his soul (transferred to his portrait) and contain others (via possession). Though he seems often to 
be alone, we know Dorian is not singular; Lord Henry features in some of the action, and even when he is not present, "to a large extent the lad was his own [Lord Henry's] creation" (51). Thus, part of Lord Henry is always with Dorian, as is the haunting presence of the painting, both always driving him on in search of pleasure. The pleasure he finds is full of other things that possess him as well: his possessions, like his jewels and embroideries, his opium habit, and his sexual appetites. The promiscuity of his interests requires him to constantly empty himself of his own identity so that he may take on new names, new disguises, and new social roles. Without his portrait, he would not have experimented so liberally with his sexuality and pleasures; without Lord Henry's influence he would never have wished for his portrait to age instead of his body; without Basil's desires for Dorian the portrait would not have been capable of holding his soul. Dorian's identity, then, is not self-formed except insofar as he willingly welcomes others to form it. But it is formed, undoubtedly, from the influences of his queer position and magic.

The Picture of Dorian Gray is often read as a cautionary tale showing what can go wrong when one resists dominant ideologies of age and youth, cause and effect, and self and other since it ends with the protagonist's death. But its original critics, and perhaps modern ones as well, can see it as a tale that espouses such danger: Dorian's freedom from social norms and consequences is appealing to people who wish for such variety and unrestricted expression of promiscuous desires. For Dorian, a queer identity and sexuality are enabled by the magic of his portrait, a fantastic device that allows him to explore life's potential. For us, perhaps the novel itself can operate in a similar way, as our time-slip talisman — after all, Dorian becomes possessed by the Yellow Book; why should we not embrace being possessed by Dorian? The book operates as a mystical conduit, like all of literature, allowing the time it was written and the 
life it was written about to be experienced by reading it in the present. ${ }^{22}$ But Dorian also believes that the Yellow Book is a "prefiguring type of himself. And, indeed, the whole book seemed to him to contain the story of his own life, written before he had lived it" (108). Every time a reader picks up the novel, the cycle of influence continues. We, the modern readers, can perhaps see ourselves 'prefigured' in Dorian, as we also strive for queer potential by opening ourselves to the same queer time and possessive magic that he experiences. As Freeman says, we can "min[e] the present" reading experience "for signs of undetonated energy from past revolutions" in the story (xvi). Dorian's addictions, his erotic exploits, his binges and parties can become our own strategies of resisting normativity using queer multiplicity and the supernatural.

${ }^{22}$ Indeed, Amis et. al. frame their "time-slip" theory primarily around "the romance of the archive," claiming that such literary connections to the past (and subsequent possession by the written work) are the cause of time-slippage in many stories. 


\section{Chapter 3: The BeEtLE’s Mesmeric Language of QueEr Desire}

While some Victorian writers explore supernatural events and include queer characters or communities, the narratives often submit to hegemonic pressure and end in a way that ultimately condemns and stigmatizes non-normative desires and remains skeptical or ambiguous about mysterious metaphysical events. Tidy, normative endings of potentially subversive works reinforce the status quo and gesture toward the thick fog of social and cultural anxiety that surrounded questions of sexuality and the supernatural. The Beetle, by Richard Marsh, portrays these anxieties more directly: the story uses mesmeric occult ritual and bizarre erotic acts to terrorize characters and readers alike. The context of The Beetle is especially important because of this obvious unease: it was published in 1897, after the Wilde trials and the same year as new vampire novels ${ }^{1}$ which betray similar cultural fears of degeneracy, moral decay, and promiscuity. Marsh's novel also relies heavily on Orientalism for its ability to generate contemporary interest, relation to foreign mesmeric practices, and driving narrative devices: The Beetle projects a slew of negative characteristics onto a foreign body, revealing the potential of those characteristics to disrupt normative British identity. Though the novel ends in a seemingly-normative way that kills the evil outsider, closer examination finds lingering subversion in the heart of London.

Late Victorian Orientalism was a source of much interest because of its influential alternative spiritualities and occult aspects, and, as Joseph Allen Boone has clearly shown, orientalism was a trend that provided an arena for experimental sexual practices as well. The emphasis on Orientalism in Marsh's novel is a way of portraying the two communities of

\footnotetext{
${ }^{1}$ Bram Stoker's Dracula and Florence Marryat's The Blood of the Vampire were also published in 1897.
} 
mysticism and queer desire simultaneously, and the unknown Beetle figure reveals the two subcultures by representing their unification in her body: she is the shape-shifting figure of ancient cult worship who takes part in mystical rituals and is described as ambiguously gendered, and takes both men and women as sexual objects. Edward Said argues that Orientalism can mean many different things at different times (and even at the same time), ${ }^{2}$ and the context of The Beetle helps expose the critical intersection of sexuality and spirituality that Orientalism potentially means in the novel. Marsh uses the flexibility inherent in Orientalism to transform the language of occult mysticism into a code for queer sexual desires. Thus, while Orientalism sets up conflict between self and other, foreign and domestic, male and female, straight and queer, and magic and science, the intersections and overlap of these categories in mesmerism tellingly reveal that the aberrant is always already inside the normative.

Within the trappings of Orientalism, The Beetle is a mystery thriller, part horror, part cautionary tale, and wholly gothic. Set in the foggy streets of London, our Brave Heroes seek to find and vanquish the evil, mysterious foreigner. Gothic texts, whether at the end of the eighteenth or nineteenth century, project those fears which represent threats to society into the terrifying monster, the ghost, or the abhuman figure. Kelly Hurley aptly describes why this

${ }^{2}$ Importantly, Said describes how he uses the term, which I will echo: "Orientalism is the generic term that I have been employing to describe the Western approach to the Orient; Orientalism is the discipline by which the Orient was (and is) approached systematically, as a topic of learning, discovery, and practice. But in addition, I have been using the word to designate that collection of dreams, images, and vocabularies available to anyone who has tried to talk about what lies east of the dividing line" (73). 
might be the case, saying that the genre "reemerg[es] cyclically, at periods of cultural stress, to negotiate the anxieties that accompany social and epistemological transformations and crises" (5). Jack Halberstam explains, "the monster itself is an economic form in that it condenses various racial and sexual threats to nation, capitalism, and the bourgeoisie in one body" (Skin Shows 3). The Beetle, in combining the Oriental other and the gothic monster in the antagonist, creates a clear set of 'bad' characteristics - qualities which line up neatly with the outcast other and serve as a negative example at a time of sexual and spiritual uncertainty. The text operates as a cautionary tale that literally demon-izes the foreigner, representative of non-normative sexualities and the supernatural, in order to attempt to (re)establish normative behaviors and identities. But, as in many gothic tales, the symbol of the othered monster expresses potential in its subversive qualities - a reader can learn how to emulate as much as avoid. We may not be able to shape-shift into terrifying occult figures, but when we learn to read the sexual symbolism of the Beetle's mesmeric powers, we can see the transgressive potential of Marsh's story to reveal the possibility of queer desires.

While The Beetle purports to horrify readers with its negative example embodied by the monster and othered via Orientalism, it is ultimately indeterminate, revealing the potency of sexual liminality through the vocabulary of mesmerism. The Beetle's threat, then, is portrayed overtly as mystical: her powers of hypnosis symbolize the dangerous control that she wields. Fears of autonomy and control also accompanied the earliest criticisms of Franz Anton Mesmer's theories of Animal Magnetism and its uses. ${ }^{3}$ Skeptics accused him of "ridiculous,

\footnotetext{
${ }^{3}$ Mesmer's name supplies the root of "mesmerism," of course, but other terms bear short explanation. The force Mesmer identified as being manipulated during a mesmeric session and
} 
prearranged fraud," highlighting fears of manipulation and influence (Mesmer 36). Stephen Jay Gould explains, "people in power feared the irrationalism, the potential for sexual license, the possibility that Mesmer's mass sessions might rupture boundaries between social classes" (188). Critics' concerns were merited because of the seeming efficacy of Mesmer's treatment practices; his (and his followers') ability to control the actions, speech, and senses of his patients was astounding. In cases examined by Alison Winter, Janet Oppenheim, Douglas J. Lanska and Joseph T. Lanska, Gould, and included in Mesmer's own treatise, subjects were under the complete control of the mesmeric practitioner. Mesmer's theory about Animal Magnetism prompted questions about the self (Is the self located in the brain? What is the soul? The will? What is magnetic fluid?) and the influence of the other. After a French commission was ordered to investigate and new, scientific approaches of study were applied, the mesmeric trance was found to be largely nonreplicable and faded from popularity. ${ }^{4}$ But mesmerism surfaced in England in the 1840s and '50s and was popular as a spectacle, and it resurfaced during Marsh's

the object of his study is Animal Magnetism. Later practitioners preferred to focus on the subject's resulting trance state, so 'mesmerism' was somewhat reimagined and renamed hypnotism by James Braid (from the Greek word for 'sleep') in the 1840s (Oppenheim 214). I use the terms "mesmerism" and "hypnotism" interchangeably.

${ }^{4}$ For a full account of Mesmer's rise to fame, treatments, the commission and its findings, see Lanska and Lanska. 
time at the fin de siècle because of the lasting appeal of "the role of imagination and suggestion in giving the mind dominance over the body" (Oppenheim 210). ${ }^{5}$

Understanding Mesmer and his contemporaries' concerns about the division of the self and the mind, autonomy, subject interacting with object, and fluid, physical forces, we can clearly identify the parallel to sexuality. Though subjects were often women and mesmerists often men, establishing a heteronormative power dynamic, same-sex application of hypnosis was not uncommon. Indeed, hypnotism between men involved more intimate touching, such as “interlaced fingers" with "the subject's knees between the mesmerist's," and Winter describes an illustration of two women "in the mesmeric state" as sitting so close together "that their skirts blend together" (140-1). Such physical postures during the trance symbolize the mysterious "influence" of one person on another and the meeting of minds and exchange of mystical fluids taking place. It is clear, then, that animal magnetism has always included the possibility of the kind of erotic attraction that the term came to describe colloquially in the twentieth century. Because of these fundamental connections, I argue that Marsh articulates the possibility of nonnormative sexual desires using the Beetle's mysterious mesmeric abilities. Though the Beetle's monstrous Oriental identity is highlighted, she also wields impressive hypnotic influence, and this symbol of aberrant sexual seduction proves to be the real threat and focus of the novel.

\footnotetext{
${ }^{5}$ Leighton elaborates by tracing the study of mesmerism from Braid's renaming it 'hypnotism' in the 1840 s to its revival as a public medical / scientific debate within the pages of the British Medical Journal in the 1880s and '90s. See "Hypnosis Redivivus" for more.
} 


\section{The Adept Mesmerist}

Though Marsh's novel appears after the height of mesmerism's general popularity in the 1850 s, it reflects the scientific revival in relation to hypnotism in the 1880s and 1890s, when mesmerism was an intense field of study for "psychical researchers," who approached supernatural phenomena with "circumspection and even, in some cases, skepticism" (Oppenheim 3). Psychical researchers and spiritualist believers together formed the Society for Psychical Research, or SPR, in the 1880s to investigate a number of phenomena, including mesmerism (Oppenheim 141). Like Mesmer himself, a practicing scholar and medical doctor, these researchers attempted to make what we might consider "spiritual" into observable and predictable science, blurring the lines between mental and physical as well as mystical and scientific. Winter agrees, saying that the practice of mesmerism, its proponents, and its skeptics combined to yield ideas that "could become tools for modeling the nature of human interaction and social power" (5). The mesmerism portrayed in The Beetle is thus not wholly incompatible with science and, indeed, the two fields complement each other by providing alternative explanations for mysterious occurrences and models for human interaction.

Mesmer's original theory of Animal Magnetism, along with its later mutation into hypnotism, is surprisingly accurately represented in The Beetle. For example, understanding that mesmerism was under scientific inquiry at the time of Marsh's writing helps explain why Atherton so easily refers to himself and his chemical work as magical. The two categories were inseparable, and so even Atherton's (scientific) resistance to the Beetle's mesmerizing power becomes evidence of their interplay. Though he attributes it to his strong mind, it is perhaps instead because he is also a mesmerist—a psychical researcher of sorts, rather than a susceptible test subject. Relation to science aside, this strength of Atherton's highlights a specific 
component of Mesmer's theory: the practitioner's ability to manipulate the "ebb and flow" of the subject's magnetic fluids is key (Mesmer 28 and throughout; notably Proposition 4); indeed, Mesmer says that "in a word, they [physicians] alone are qualified to put it into practice" (55), and in the later decades of the nineteenth century, similar concerns were raised about the pedigrees and professionalism of practitioners (M. E. Leighton "Hypnosis" 111, 113). Atherton is able to withstand the Beetle's mesmerism: he recognizes the Beetle's ability immediately in her eyes, but narrates that mesmerism works best on "weak and foolish folk" and that, "the sensitive something which is found in the hypnotic subject happens, in [him], to be wholly absent" (105). Atherton demonstrates that Mesmer has established a hierarchy of magnetic powers, the strong 'influencers' able to hypnotize the weaker patients. This core component of Mesmer's theory is repeatedly invoked in The Beetle, as only the weak or susceptible characters fall under the Beetle woman's hypnosis, and the process of mesmerizing is described in surprisingly accurate detail.

During a hypnotic session, Winter says that the "mesmerist and subject would stare into each others' eyes as he made 'magnetic passes' over her" and then, that "a strange communion would develop between them: she would speak his thoughts, taste the food in his mouth, move her limbs in a physical echo of his" $(2,3){ }^{6}$ Holt is especially struck by the Beetle's mesmeric movements, since, unlike Atherton, he seems to be unaware of what is happening. Precisely

\footnotetext{
${ }^{6}$ The gendered language here reflects what Winter explains was most common: men were mesmerists and women were their subjects. Interestingly, this muddles the Beetle's gender (and Holt's, and Lessingham's) by placing her in the masculine position of power, as I discuss below. The theme of gendered participants is also discussed at length by Rebry.
} 
matching Winter's description, Holt first sees the Beetle's eyes approaching him from across the dark room, and he says, "not for an instant did [his] glance pass from them" (50-1). The importance of eye contact is clear, as Atherton and others also continually comment on the quality of the Beetle's eyes. Holt narrates that he behaves "mechanically, like an automaton" while under the Beetle's spell, and that when she asks him questions, the answers "came from [him], not in response to [his] own power, but in response to [hers]" $(52,54)$. Such overpowering influence is troubling to readers, as Holt is not even in control of his own mind.

The Beetle's later instructions to break into Lessingham's house have a similar effect: as Winter describes, Holt's actions are "a physical echo" of what the Beetle does or wants him to do - she directs him to the house, which seems to prove she can see out of Holt's eyes, and she sends him commands to find the particular room and cabinet that hold Marjorie's love letters. Indeed, Winter writes that one of the tests of hypnotism was to force the subject to do things while entranced that they could not perform under their own power, such as lift heavy objects (53). Holt, while hypnotized, has difficulty climbing into Lessingham's house, but his trance state forces him to accomplish the feat by force of (the Beetle's) will. This power that the Beetle has over even Holt's physical capabilities, the "strange communion" caused by the eye contact, particular physical movements, and commands are precisely the links that confuse the self and the other and concerned early Mesmerism skeptics. The Beetle's mesmerizing powers allow her to project herself into another person and remove his autonomy. She becomes each of her victims, and they, in turn, lose their ability to act independently. Her mesmeric trances link the self and the other mentally and physically.

Marsh's accuracy in portraying mesmerism is fascinating for two main reasons: first, he is separated from Mesmer's theory of Animal Magnetism by more than a century, and yet the 
popular appeal and efficacy of hypnotic powers is key for his story. Despite its mutations into various branches of more contemporary science (anesthesiology and psychoanalysis for example), Marsh uses the unexplainable trance state as his plot device (Winter 348). Winter says that the lasting interest is in part due to mesmerism's "slippery and ambiguous" nature, resulting in "enormous possibilities" for exploring its meanings and ramifications (346). Second, then, Marsh taps into these "slippery and ambiguous" meanings of mesmerism to use the practice as a vocabulary and metaphor for another form of power exchange, influence, and connection of mind and body_namely, sexual desire. Indeed, Martin Willis and Catherine Wynne say, “Mesmer's quasi-sexual ritualism [...] was responsible for fuelling its literary possibilities” (8). The Beetle's popularity when published (it initially outsold Dracula) points to its success despite the use of mesmerism as symbolic of desire.

In an account of a French report, ${ }^{7}$ Michael R. Finn describes the common gendered roles of male mesmerist and female subject in order to highlight the potential for the mesmeric trance to lead to sex, either literally or (just as dangerous) metaphorically; the secret report says, "there are... certain moments of high excitement that have a hidden but natural cause, a specific emotional cause to which all women are more or less susceptible and which, even via a distant influence, as emotions accumulate to their peak degree, can contribute to a convulsive state that can be confused with other convulsive movements" (qtd. in Finn 98). Finn explains that these

\footnotetext{
${ }^{7}$ Though not quoted at any length, Tatar, Weyant, and Rebry each include a very brief reference to what may be the same report, claiming that it was filed off the record by the official commission appointed by Louis XVI. See Tatar pp. 22-3 and Weyant p. 101. Rebry calls it a "private addendum" (3).
} 
subjects, already known to be sensitive to the animal magnetic fluid, were also so sensitive to stimulation that they experienced a trance crisis as a sort of orgasm. Moreover, the stroking or gentle touching required to put a subject into a mesmeric trance was also loaded with sexual meaning: the same secret French report says, "when...one touches a woman in one spot, you might say that she is being touched everywhere" (qtd. in Finn 98). This private report is noteworthy in its frankness, but the ramifications are even more astounding: as discussed above, same-sex mesmeric sessions were perhaps more intimate, even, than this. If the male/female trance experience was so akin to (hetero)sexual intercourse, the male/male and female/female sessions were just as intensely erotic. These underlying meanings combine to symbolize a covert and complex network of queer sexual desires in Marsh's novel.

\section{The Foreign Seductress}

Mesmerism has, at its heart, seeds of sexuality. Mesmer's language of exchanging fluids, influencing, touching, and penetrating the mind of the subject certainly points to the practice's parallel to erotic activity. But it is not only The Beetle's accuracy in representing hypnosis that invokes underlying sexual tensions: Marsh uses Orientalism to add a layer of complexity and bolster the symbolic language of mesmerism to open up the possibility of queer erotics. While Orientalism is generally defined as the way the Western world conceives of the East, spatial distinctions, as well as the strict demarcations of self and other (as Western and Foreigner) were more difficult to manage. Formulations of Orientalism require, for example, the British subject to physically travel to the Orient, or to surround himself with Oriental objects and research, thereby bringing the Orient to England. Boone and Said both acknowledge this conundrum, and assert that the layers of meaning created and sustained by Orientalism are implied by each other, 
creating a mess of signifiers and referents. Boone says, "the geopolitical realities of the Arabic Orient become a psychic screen on which to project fantasies of illicit sexuality and unbridled excess" ("Vacation Cruises" 89). These "fantasies" reflect the subject crafting the fantasy as much as the object onto which it is "projected." Thus, the very concept of this projection, in fact an echo of the mesmerist's projection of will onto the entranced patient, necessarily connects the subject and the object via the fantasy.

Like hypnotism, Orientalism is full of potential meaning for Marsh, and although there is nothing essentially Eastern about mesmerism (Mesmer came to fame and practiced mainly in France), "projecting" such mysterious, seemingly supernatural phenomena onto the East was not uncommon. Infamous spiritualist Madame Blavatsky claimed to have drawn (divine) inspiration for her Theosophy from Eastern sources such as Indian and Tibetan Mahatmas, including Buddha and Zoroaster, and her famous text, published in 1877, is called Isis Unveiled (Oppenheim 167-177, 163). It is clear that the conversation between spiritualism of many types and Orientalism was already established when Marsh was writing the novel. The two fields are complementary in many ways, perhaps most importantly in their flexibility of uses and applicability. Said explains, "the Orient is less a place than a topos, a set of references, a congeries of characteristics" (177). The Beetle is this very "set of references" all bundled into one (gothic) body. Indeed, Halberstam says, "the monster functions as a monster [...] when it is able to condense as many fear-producing traits as possible into one body" and adds, "The Oriental" figure serves as a "generalized code of fear" (Skin Shows 21, 14). In much the same way, mesmerism and its projection into Egyptian occult magic can signify anxieties about the self and other, control, power, and autonomy. These vocabularies work together to speak for the potential of queer sexual practices. 
Just as there is evidence for the very real sexual threat of mesmerism, the sexualization of Orientalism is easy to identify. In many texts, the East is portrayed as a sensual woman ripe for domination - the West is the hyper-virile, masculine invader — and so perhaps the most telling dynamic of Orientalism is based in gender norms and heterosexual erotics. The association between the East and sex was "a remarkably persistent motif" according to Said, and "the Orient was a place where one could look for sexual experiences unobtainable in Europe" $(188,190)$. To read the Beetle as fundamentally sexual is likewise no difficult matter: indeed, in the brief explanation of the Cult of Isis we get from Lessingham, he all but says his experiences with the Beetle are sexual. After being "entranced" by the Woman of Songs, Lessingham finds himself naked and being kissed by her $(239,241)$. She calls him "beloved" and his narrative breaks down as he attempts to describe her assault: all he can manage is, "I lay there like a log. She did with me as she would" (243). Lessingham says that he remained in the temple for "two unspeakable months," implying that the "unspeakable" ordeals of the woman offering "her loathed caresses" were continuous or at least regular (243-4). Especially because he calls her the “Woman of Songs," Lessingham's account is perceived to be heterosexual, and it is almost graphically erotic.

Open sexuality is mapped onto the Beetle, and even though there are plenty of other, chaste romances in the story, her type of sexuality is aberrant - it is at times homoerotic, promiscuous, openly desirous, devious, sadistic, and non-consensual. Boone, who has established that Orientalism implicitly indicates homosexuality and homoeroticism, says, "Of all the regions in the Near East, Western writers most readily associate ancient and modern Egypt with the spreading 'contagion' of homosexuality" ("Vacation Cruises" 93). To revisit the above example of Lessingham's time with the Woman of Songs, his tenure as her sex slave is loaded 
with descriptions that point toward homoeroticism, since the Woman of Songs is the dominant partner. ${ }^{8}$ Indeed, his presence in Egypt can be read, via Orientalism, as purely sexual. W. C. Harris and Dawn Vernooy explain, "in the simplest terms, the eighteen-year-old Lessingham is in Cairo on a tour of sexual slumming" and that "to travel in the East was to seek, among other experiences, an escape from the rigidities of Western conventions — intellectual, spiritual, and, perhaps most often, sexual" $(355,354)$. Boone also identifies homoerotic potential as a major draw for sexual tourism in Egypt and the East, and it is no stretch to argue that Lessingham's goal in taking his midnight walk through a bad part of town was to find almost exactly what he ended up getting — sex decried and denounced by Western society but readily accessible in the East.

Lessingham's time in the den of the Children of Isis is thus complex in a number of ways: he is portrayed as hyper-virile (because he is British, male, etc.) but also entirely entranced and emasculated by the Woman of Songs. Hurley describes the contradictions of Lessingham's captivity:

He behaves as a female subject — passive, resistless, voiceless, and inert - when under the control of this sexually aggressively, strong-willed, and thus ultra-masculine woman. But to identify this scene as one of symbolic castration obscures the crucial point that, speaking literally for the moment, Lessingham is anything but castrated: he is sexually aroused again and again. (144)

Because Lessingham is not entirely feminized by the dominance of the Beetle / Woman of Songs, but rather maintains his virility, both partners can be read as masculine and thus the

\footnotetext{
${ }^{8}$ Rebry evaluates these gender dynamics at length.
} 
horror of the scene is not solely based in mesmerized rape, sadism, or quasi-beastiality, but also because it is homoerotic. Indeed, Harris and Vernooy astutely point out that Lessingham's unwillingness to talk about his experiences in Egypt draws a distinct connection to "the love that dare not speak its name" (363).

\section{The Covert Conjugal Conversation}

The historical contexts surrounding Marsh's use of both mesmerism and Orientalism are important to establish, along with their independent (though certainly interwoven) connections to sexuality and homoeroticism, because they are part of a particular contemporary conversation already circulating in the fin de siécle. As the scholars cited above agree, both mesmerism and Orientalism provide writers with complex, multi-faceted signifiers that I argue Marsh uses to express the potential subject / object interactions in queer erotic encounters. These vocabularies of symbols, tropes, and contextual meanings allow The Beetle to present aberrant sexualities to the reader concealed in the trappings of Egyptian cult magic, a language already available to those who knew how to read it. Now let us turn to what Marsh adds to the conversation.

The Beetle paralyzes both Holt and Lessingham before assaulting them, keeping them "spellbound," leaving each of them metaphorically 'bound in shackles' $(49,69)$. Lessingham narrates, "her touch had on me what I can only describe as a magnetic influence," echoing Mesmer's own language of animal magnetism (240). The Beetle also "play[s] some of [her] tricks" on Atherton's servant and prevents Marjorie from praying by silencing her $(108,166)$. Her ability to transform into her beetle avatar serves as the keystone of her identity and, indeed, highlights the "Animal" part of her ability to manipulate Animal Magnetism and induce a hypnotic trance. In each of the main trance episodes described in the novel, those of Lessingham 
(already discussed), Robert Holt, and Marjorie Lindon, a mesmeric exchange is accompanied by concealed erotic actions. Each time, the Beetle's hypnotic powers and bizarre, abhuman body is described in terrifying detail, shocking characters and readers alike while masking the underlying aberrant sexual desires. As established, Lessingham's encounters can be read as queer based on the gendered power dynamics with the Woman of Songs, and, similarly, the Beetle's encounters with Holt and Marjorie are queer. Mesmerism, a symbol of dominance and control, allows the Beetle to inhabit her subjects' bodies literally and metaphysically.

Holt provides the first glimpse of the Beetle's queer desire, since he is the first narrator to be dominated and physically assaulted by her. Holt is paralyzed by the Beetle's mesmeric power, then, he narrates, "it mounted [him]," and her legs "embraced [him] softly, stickily" (51). He calls the Beetle's actions an "invasion," her body "heaved" and she touches his neck and lips, and she seems to kiss him, her "huge, slimy, evil-smelling body" covering his face. ${ }^{9}$ The language surrounding the episode clearly depicts the Beetle "enact[ing] a normatively male sexual dominance" (Harris, Vernooy 353); she commands and he obeys. Holt is eventually left powerless, naked on the floor, where the Beetle "prod[s]," "thrust[s]" fingers into his mouth, and kisses him, which he narrates, "the soul of something evil entered into me" (57). These virile verbs, coupled as they are with Holt's insistence on using masculine pronouns for the Beetle, make his hypnotic domination distinctly homoerotic. Rebry explains, "the sexual undertones of

\footnotetext{
${ }^{9}$ On the other hand, her smell and the tactile stickiness and slime described here indicates that the Beetle is a huge, monstrous vagina. Since Holt is emasculated - he says, while he is under the Beetle's power, "for the time I was no longer a man"- - the Beetle's vagina-like description means the scene can still be read as homoerotic (54).
} 
this attack, though amplified, reflect the extensive public belief that mesmerism was a form of sexual seduction, with its emphasis on intimate physical contact and the exchange of fluid" (8). Furthermore, while mesmerized by the Beetle, Holt is seen "slithering down the Apostle's pillar" by Atherton, a clearly homoerotic euphemism (83). In each of these scenes, the terror of the mesmeric subject and the reader alike is tied to the hideous body of the Beetle-as-beetle or her complete domination of her victims by mesmerism, but the language of its mystical bodily transformation and the subject's hypnosis indicate graphic queer sex acts.

The other character susceptible to the Beetle's mesmeric powers is Marjorie Lindon, a more traditional hypnosis subject because she is female. Marjorie is subjected to the terrifying advances of the Beetle one evening when it enters her room: in a near-stupefied state, she strips herself in a "holocaust of dainty garments," turns off the light, and jumps into bed, hoping to escape. But the Beetle "alight[s] upon the coverlet" and while Marjorie is immobilized, slowly walks up her body, and "beg[ins] to find its way inside" (207). The homoerotic implications of the scene are clear: it "creep[s] between the sheets," comes "nearer and nearer," and finally Marjorie faints away in terror or trance. Though it is unclear whether Marjorie is mesmerized in this scene, she is speechless, unable to pray or call for help, and acts impulsively — all indicators that she is, perhaps, under the Beetle's influence. Mesmer and his followers recorded many cases of manipulating the magnetic fluids of subjects through walls, screens, without touching or eye contact, etc., so it is no stretch to believe Marjorie was under the Beetle's influence without her visible presence. Later, the Beetle mesmerizes Marjorie again and forces her to strip a second time, cut her hair, and dress as a man. The unspeakability of Marjorie's hypnotized episodes and the lasting trauma they cause parallels Lessingham's inability to specify what the 
Beetle does to him in the temple of Isis and demonstrates the horror of losing agency as an unwilling mesmerized subject and sexual object.

While the Beetle and Marjorie's brief erotic episode is a scene of female-female samesex desire, the Beetle's gender mutability also allows her to operate as a male during encounters with Holt and Lessingham. So even though the Beetle, we know, is female-sexed, each of her sexual interactions with men can be read as same-sex eroticism as well. Boone says that "the ghostly presence of something 'like' male homoeroticism [...] haunts many Western men's fantasies and fears of Middle Eastern sexuality" (Homoerotics xx). The key words here are "something like;" homoeroticism can be read into the Beetle's sexuality even though she is female because of the "haunting" of the trope within Orientalist texts, regardless of whether literal homoeroticism is present. This reading of male-male desire is made possible by the Beetle's aggressive, masculine pursuit of her sexual objects, her frequent characterization as a male (including other characters' continuous use of masculine pronouns when speaking of her), and the language used in these particular scenes, which centers on touching, penetration, and dominance. Beyond the haunting presence of homoeroticism in Orientalism, the Beetle's role as the mesmerist, usually a male, puts her in the seat of power, and her hypnotic control over her erotic partners queers every encounter. The languages of mesmerism and Orientalism reinforce each other as Marsh probes questions of sexual agency, autonomy, erotic subject and object, and control with a novel that ultimately opens the conversation to include queer desire instead of clear answers.

One contemporary theory could, perhaps, explain the potency of the Beetle's sexuality and magnetic power: the Waisbrooker theory, which was proposed in 1893 and was part of the Spiritual Darwinist movement (but explicitly uninterested in eugenics). Waisbrooker believed 
that spiritual awakening or rapture could only occur through the body's experiences, and that sexual bliss would lead to spiritual ecstasy. Sarah A. Willburn explains, "Waisbrooker believed that the only way to salvation and spiritual enlightenment is through refined sex acts in which spiritual (rather than material) fluid is exchanged" (73). Without directly drawing the connection, Waisbrooker describes a new kind of Animal Magnetism that, instead of controlling the body's natural balances, could add to a person's spiritual evolution: "The sexes [...] have an inherent electrical charge. Sexual magnetism, though, also contains content" (76). Sex allowed for the transfer of the magnetic charge between sex partners, leading to orgasmic spiritual awakening. The direct echo of Animal Magnetism and the "fluids" of spiritual exchange again beg the comparison between the mindless moment of orgasm and the trance state. Both theories account for the mingling of subject and object, but Waisbrooker directly includes the sexual desires and feelings that mesmerism hides as a worrisome side-effect of the trance. The Beetle's powers, though described in terms of her transforming body and powers of mesmerism, certainly involve similarly ritualistic eroticism.

Lessingham's description of the temple of Isis implies that sex is integral to the religious rites of the Children of Isis. Although he has difficulty speaking of the atrocities he has seen, it is noteworthy that he calls them "orgies of nameless horrors" (243 emphasis added). ${ }^{10}$ These rituals appear to not necessarily require the male sexual object, only the female sacrifice. Lessingham's presence, then, is part of the religious aspect of the ritual more as a secondary demonstration. Though the Woman of Songs derives obvious pleasure from Lessingham's

${ }^{10}$ The sexual sense of the word Orgy, OED confirms, has been in use since at least 1706 . The word is used again to describe the temple activities on page 244 . 
sexual enslavement and their copulations, he says that she is especially enthusiastic after a human sacrifice, "drunk with an insensate frenzy, delirious with inhuman longings," indicating the tie between their sex and the spiritual rite (244). Furthermore, Lessingham is in a trance throughout his time in captivity, tying the power of mesmerism to both religious ritual and sex. Mesmerism unites the self and the other via a similar penetration of the subject, and, as in Waisbrooker's theory, 'spiritual fluid' is exchanged (Willburn 73). Using the Waisbrooker theory, we could speculate that the Children of Isis have mesmeric and transformative powers because they have spiritually evolved through centuries of holy sex.

The parallel between sex and hypnosis creates a continuity between the body and mind as the union of sex and mystical trance "make a single identity impossible and replace it with a plural one" (Willburn 88). This "plural identity" is evidenced in the above discussion during the trances of Lessingham, Holt, and Marjorie, as they experience sexual and mental unity with the Woman of Songs or the Beetle. Interestingly, such pluralized identity also haunts the novel as we gradually trace the Woman of Songs, Arab man, and Beetle woman as the same individual. Her mesmeric capabilities, coupled with her unfixed gender and mystical ability to turn into a beetle, make such plurality of identity possible. Contextually, this plurality is also one of the fundamental concerns of mesmerism: during its revival in the 1880s and ' 90 s especially, professional (medical / scientific) evaluation of mesmerism hinged on issues of 'the will' and individual agency.

But a plural identity, made possible by mesmeric influence, is also a radical and potentially powerful mode of interpersonal - and sexual-relation. Maria Tatar says that in the secret report filed on early mesmerism, the writer(s) "noted that female patients often forged a strong emotional bond to their physicians" (22). Described as "the phenomenon of 
transference," this connection between mesmerist and subject was feared for its immoral implications of lowered inhibitions and sexual arousal (Tatar 22). As in The Beetle, however, the trance is the necessary mode of connection; the fluid mesmeric exchange facilitates a sexual bond. We can thus read each of the Beetle's hypnotic encounters with her victims as explicitly erotic as well as metaphysical.

\section{A Cautionary Tale}

It is noteworthy that the very modes that allow Marsh to suggest the possibility of queer desire are the aspects of The Beetle that are also designed to terrorize and fascinate the reader. This abject attraction and repulsion of the Beetle's hideous body, her uncanny ability to control others through hypnosis, and her Oriental otherness combine to fascinate readers who cannot look away from the spectacle. At the fin de siècle, the conversation circulating about mesmerism was negatively charged: the dangerous plurality of identity meant that it was unclear who was responsible for the actions of the hypnotized subject, and mesmerists gained a bad reputation. Mesmerists were popularly seen as manipulative criminals and predators, taking over their victims' minds to commit immoral deeds (M. E. Leighton "Influence" 206). ${ }^{11}$ Mary Elizabeth Leighton says this was based on a number of fears, including, "first, that hypnotism rendered the female subject prone to the predations of malevolent operators; second, that hypnotism could

\footnotetext{
${ }^{11}$ Willis and Wynne point out that the discourse surrounding tests of mesmerism was distinctly judicial: witnesses were called upon to testify to the veracity of a trance and judge whether the practice was legitimate (9). This is echoed in the form of Marsh's novel, which uses four independent narrator-witnesses, concluding with a case-study by Augustus Champnell.
} 
redirect the subject's moral compass, subjecting her to the will of the operator and removing all moral and sexual inhibitions," and that these uncertainties were perpetuated by popular literature ("Influence" 206, 213). Though he avoids being hypnotized by the Beetle, Atherton vocalizes this public perception of hypnotists when he narrates, "The scoundrel had almost succeeded in hypnotising me. [...] A shiver went down my back, - what might have occurred if I had not pulled up in time! What pranks might a creature of that character not have been disposed to play?" (144). Mesmerism, like aberrant sexuality, had distinctly illegal or immoral implications. Marsh's novel, then, is just one of many (Leighton names Henry James' The Bostonians, Esmé Stuart's In His Grasp, George Du Maurier's Trilby, and The Beetle as examples) that use the hypnosis as shorthand for criminal activity, making the hypnotist the antagonist or villain. Leighton explains:

These novels, among many others, provide various models of the hypnotist: as powerthirsty exploiter of vulnerable female subjects; as money-grubbing faux spiritualist; as vengeance-seeking charlatan; and as innocent-seeming, clandestine schemer. Regardless of the details of the authors' characterizations of the hypnotist, however, the broad strokes remain consistent. In each novel, the hypnotist is construed as a criminal: a representation that figured in the press of the 1880 s and 1890 s as well as in fiction. ("Influence" 221)

The popular view of mesmerists as criminals, then, was multi-faceted but widely applicable; it is easy to identify several of these tropes in the figure of the Beetle.

The Beetle woman would have been a recognizable threat for many reasons: as Leighton explains, the cultural milieu saw mesmerists as criminals, Orientalism ensured that the foreign other was seen as a threat, and her actual use of hypnosis in the novel would have been seen as a 
dangerous loss of self for her victims, who were forced to act against their will. Since the Beetle's surface characteristics — these recognizable Oriental and mesmeric codes—were seen as a threat, their underlying sexual meanings are also perceived as threatening. But the Beetle's specific language of self and other, exchanging fluids, control, and domination is an especially threatening and powerful portrayal in the ancient occult magic of the shape-shifting antagonist, and so her queer desires are also especially potent. Victoria Margree explains, "there is an equation produced between sexual possession and mesmeric possession: to be subjected to the will of another is to be invaded in a way that is equivalent to a sort of (mental) rape" (67). Both the Beetle's reputation (as a literary mesmerist and Oriental) and her actions reveal how dangerous she really is, and Marsh's villain serves to reinforce the popular conception of the dangers of mesmerists and Orientals at the same time.

The villain, then, is produced by, and also re-produces, a cultural, contextual language of evil and criminality that would have been easily recognized. Moreover, the same tropes that convey criminality convey dangerous aberrant sexual desires, reinforcing the negative example of the Beetle. Punishing the Beetle for her mesmeric abuses and sexual deviance with death-bytrain wreck and happy endings for everyone else, the end of Marsh's novel reinforces hegemonic norms of autonomy and heteronormative sexual desires. Or does it?

V. Seeds of Hope: Atherton as "a nice type of ideal citizen." 12

Figures like the Beetle, bundles of negative traits projected onto a single monstrous body, "represent contamination and threaten an orderly vision of human existence; they break down

\footnotetext{
${ }^{12}$ Atherton talks to and about himself, ironically (Marsh 99).
} 
cultural categories and signify social taboos" (Hutchinson, Brown 4). These "taboos" are, importantly, already present in London — both literally in the person of the Beetle and in the undercurrents of normativity. For example, the Beetle's gender and sexual preferences are indeterminate, unavailable to separate into acceptable behaviors or taboos because their complexity stems from the overlap of her foreignness and mesmeric powers. Boone explains the constellation of forces at work:

The tendency to associate Middle Eastern homoeroticism with a rigid active/passive model subscribes to the widely held belief that, particularly in third-world 'macho' cultures, the gender of the body being penetrated is irrelevant as long as the masculinity of the penetrator remains intact. But such truisms [...] unthinkingly repeat assumptions about masculine aim and object choice that reinforce binaristic understandings of gender and sexuality. (Homoerotics 68-9, emphasis original)

Since these "active/passive models" of sexuality rely on "binaristic understandings," they begin to self-destruct when applied to the Beetle. Her gender is indeterminate, as discussed above, but so is her sexuality. She takes both men and women as sex objects, indeed, even compound figures like masculinized women (in Marjorie as the New Woman) and emasculated men (Holt and Lessingham as powerless and passive).

The complex portrayal of the Beetle's sexuality may be related to its gothic mode, as it can be "an articulation of principles of pleasure that resist the sexological binaries" (Haggerty 19). George E. Haggerty explains, "Gothic novels articulate more complex 'sexualities.' Theories of sexuality that depend on the gothic $[\ldots]$ would be more varied, more sexually complex, less heteronormative, and more polymorphously perverse than any thus far considered" (Haggerty 19). Like her "mutable" gender, the Beetle's sexuality is "polymorphous." The 
Beetle's fluid sexuality impacts the perceived sexual orientations of all of her sexual victims: Hurley says that in the cases of Holt and Lessingham, "their own sexual identity is dismantled through contact with her, in part because hers is too fluid to constitute a reference point for theirs" (143). Though it appears she has homoerotic moments, it is never clear which partner's gender must be transmuted for the homoeroticism to be literal. Likewise, though much of her sexual activity is ostensibly heterosexual, mitigating factors like the "active/passive" model described by Boone in Orientalism and its parallel in mesmerism (the dominant, active mesmerist controls his submissive, passive subject) make us question the performed gender of each partner. No matter which way it is framed, the Beetle's sexual appetites cannot be mapped onto binaristic conceptions of heterosexual/homosexual without doing mental gymnastics to contort the gender, sexuality, or agency of one or both partners in an attempt to normalize one and prove the other "taboo."

Thus, the Beetle's mesmeric ability serves as not only the language of her potentially queer sexualities, but is reflected in the other characters of the novel as well. The inability to define the Beetle's queer sexual desires opens the potential for hope instead of the didactic caution conveyed by a surface reading of the novel. Instead of a tidy ending in which the big, queer mesmerizing bug is squashed and everyone else lives happily ever after, we can see the Beetle's mesmerism, Orientalism, and sexual deviance reflected in the good, normative Brits. The novel's cautionary ending, then, subverts its own message by allowing traces of mesmerism and aberrant sexuality to slip back onto the streets of London.

Where the Queer Desire Slips Through 
Lessingham's possible sex tourism and his queer encounter in Egypt with the Woman of Songs can be understood as outside the norm because the action is placed geographically in the East. But Lessingham's involvement with the incidents (and his instigation of them) still mars his Britishness and heterosexuality to some extent. Furthermore, The Beetle presents the reader with several scenes with a homoerotic subtext between British men in London itself.

Lessingham and Atherton, for example, are paired as contenders for Marjorie's affection, setting up a love triangle. Haggerty says, "the figure of two men locked in a physical and psychological bond - whether friendship or rivalry — so intense that they are spiritually a single being is everywhere in gothic fiction. This often sensational configuration is emotional and erotic in ways that defy conventional descriptions of male friendship or rivalry" (109). Haggerty's language, moreover, reflects the contemporary concern with metaphysical bonds as created by mesmerism: the men are "spiritually a single being," just as a hypnotist and his subject could share consciousness. The layer of eroticism is integral to both mesmerism and these Gothic formulations of male friendship/rivalry, and demonstrates that the Beetle is not the only representative of queer desires in Marsh's novel.

The theoretical reading of the friend/rival bond is supported by Atherton's own feelings for Lessingham: he admits that he admires Lassingham's speaking ability, political savvy, and his body. Atherton describes the politician, saying, "I admire the man,-—so long as he does not presume to thrust himself into a certain position" (that is, of marrying a woman), "he possesses physical qualities which please my eye — speaking as a mere biologist, I like the suggestion conveyed by his every pose, his every movement, of a tenacious hold on life, - - of reserve force, of a repository of bone and gristle on which he can fall back at pleasure" (108 emphasis added). Atherton does not feminize Lessingham in order to admire him—on the contrary, he highlights 
his virile power and even talks of him pleasurably falling on "bone and gristle." This proves what Harris and Vernooy say: "Though Atherton tempers the salacious nature of his pleasure by couching his observations [of Lessingham] in terms of analytical objectivity, Marsh's readers would be hard pressed to read Atherton's final pronouncement of Lessingham as being 'well hung' in any way other than sexual" (Harris, Vernooy 359 quoting 108). ${ }^{13}$ Atherton and Lessingham's bromance is neatly tied up in two traditional marriages at the end of the novel, folding such homoerotic hints back into normative contemporary ideology. Rather than being punished, as the Beetle is, this sort of same-sex desire seems to be, if not acceptable, at least not worth retribution.

Atherton, flamboyant when at all possible, has several other lines that give the reader a wink-wink-nudge-nudge hint at his homoerotic leanings: when he first starts investigating the strange occurrences of the novel, he says, "there was something about the Apostle's connection with his Oriental friend which needed probing to the bottom" (164, with similar phrase on 148, emphasis added). He also "appears to flirt with the local constable" when on the trail of the Beetle near the end (Harris, Vernooy 365). The two men complement each other and Atherton calls him a "magnificent example of the metropolitan constabulary," and the men then “admir[ed] each other's fine features and striking proportions" (281). As a character, Atherton's charisma and position as one of the narrators further demonstrate the acceptability of these kinds of queer desires, undermining the cautionary bent of the novel's ending overall.

\footnotetext{
${ }^{13}$ Harris and Vernooy add that the OED supports this usage of "well hung" for "large male genitals" for the nineteenth century.
} 


\section{When Magic Becomes Science}

The Beetle's use of mesmerism and her ability to transform are the main sources of terror in Marsh's novel, and she is appropriately punished as the antagonist. But the queer desire that the mesmerism symbolizes in its connotations of touch, lowered inhibitions, fluid exchange, and metaphysical promiscuity of identity are not so easily contained. As just discussed, the Beetle's indeterminate sexuality is reflected in other relationships of the novel. But even the mesmeric language used to convey those queer erotic desires is domesticated and survives the train wreck. Though lay hypnotists had a criminal reputation, investigations into the limits of the mind, will, agency, and metaphysical relations between practitioner and subject were all taken very seriously by the SPR and other professionals. ${ }^{14}$ Marsh uses mesmerism as a code to open the possibility of queer desires, but the figure wielding the mesmeric power is defeated by a symbol of modern technology — the train. The ultimate victory of science over unprovable mysticism echoes the same contextual shifts in perceptions of medicine, the mind, and sex. At the same time, the reformation of mesmerism into various sciences, available for serious study, allowed the underlying issues of control, connection, and possible eroticism to enter respected public discourse. Winter claims that mesmerism helped shape science, both by being absorbed into what we now consider legitimate pursuits in psychology, psychoanalysis, and physiology, but also by bringing to the public's attention questions of influence and power (27). The transition

\footnotetext{
${ }^{14}$ Indeed, professionals helped propagate the criminal reputation of hypnotists to discourage unsanctioned experiments and fraud, which gave scientists a bad reputation along with the popular performers. See Leighton, “Influence," p. 211.
} 
of mesmerism from spectacle to science necessarily included the incorporation of all the heavy symbolism of queer desires into various scientific fields along with the study of the mind.

Though Atherton is the novel's representative of science, he is also the strongest example of queer erotic desires of a protagonist, and, as I discuss shortly, sees himself as a powerful influencer of animal magnetism as well. Rebry succinctly describes Atherton as "occup[ying] a somewhat ambiguous position between scientist and magician, and the distinction between the two is continuously challenged in the text" (11). For Atherton, these different aspects are not contradictory: his mesmeric dominance and scientific experiments are not villainized as they are in the figure of the Beetle or other literary portrayals of the hypnotist-as-criminal or mad scientist. Moreover, his confident sexual comments about other men are glossed over and he is given a happy, heterosexual ending. The Beetle cannot be entirely cautionary, then, because the same characteristics that are punishable in its antagonist are allowed to survive and flourish in Atherton. ${ }^{15}$ The primary difference is that the Beetle's mode of queer erotic expression is her mesmeric abilities, while Atherton relies on his science. But we can see that the differentiation of the two spheres is continually being renegotiated - as Winter argues, it is the interplay between mysticism and science that helped form each. Atherton, then, may be the novel's symbol of science, allowed to have a happy ending, but a flair for metaphysical spectacle lingers in his science, just as queer desire haunts his heteronormative marriage.

${ }^{15}$ Willis and Wynne remark that Dracula has a parallel bad magic/good magic (science-magic) formulation: "The Count deploys mesmeric powers to satisfy his lust for blood but the occultist predisposition is scientifically reclaimed by a Dutch doctor, Van Helsing, and mesmerism becomes central in the struggle to defeat the vampire" (4). 
The duel in Atherton's lab is particularly interesting because the Beetle's mysterious transformative power is clearly portrayed as magic, but Atherton's chemistry is also discussed in terms like "magical" and that his gas kills as if its victims were "smitten by the lightening of the skies" $(131,137)$. Atherton insists on calling his discovery "magic vapour" and embraces the performative aspect of doing science popular in the nineteenth century, ${ }^{16}$ echoing performative mesmeric sessions both on public stages and in private homes. ${ }^{17}$ Rather than a triumph of science over superstition, the chapter that begins the duel in Atherton's lab presents only two options; it is titled "Magic?—Or Miracle?" Dora Grayling even calls his lab a "wizard's cave" (154), and Marjorie says "it looks uncanny" (162). The continuous conflation of the language of Atherton's science as magic indicates that the same queer desires at the heart of mesmerism are still present—indeed, they have been made acceptable as part of the protagonist's character and discourse.

During his first meeting with The Beetle, she slips past Atherton's servant, prompting him to ask, "are you a magician?" to which she replies, "You, Mr. Atherton,-—are you also a magician?" because Atherton is wearing his gas mask (104). This conflation of science and magic continues into their next meeting when they duel: Atherton has the lever for an electric machine within reach, and gives his visitor "a little exhibition of electricity" (145). The beetle woman is terrified, and Atherton threatens, "You may suppose yourself to be something of a

\footnotetext{
${ }^{16}$ See Iwan Rhys Morus, "Worlds of Wonder: Sensation and the Victorian Scientific Performance."

${ }^{17}$ See Winter for numerous examples, throughout, including facsimiles of playbills and advertisements for such gatherings.
} 
magician, but it happens, unfortunately for you, that I can do a bit in that line myself,- - perhaps I'm a trifle better at the game than you are. Especially as you have ventured into my stronghold, which contains magic enough to make a show of a hundred thousand such as you" (145). He follows this speech with another scientific display, this time showing off a liquid that causes pyrotechnics and smoke. He narrates, "it was a sufficiently simple illustration of one of the qualities of phosphorus-bromide" (145). By showing off some of the more flashy chemicals and contraptions in his lab, Atherton demonstrates that his science seems like magic to the beetle woman, a heavy-handed nod to the overlap and integrated natures of the fields as discussed by Winter. Though the novel cautions against the criminal uses of mesmerism and their hypererotic implications embodied by the Beetle, it fails to entirely condemn such practices and underlying meanings by allowing Atherton to survive.

Atherton incorporates the language of magic into his scientific demonstrations, illustrating the in-progress transition of Victorian society toward the methodical study of unexplainable events, thereby also incorporating aberrant desires. Anna Neill highlights this interplay between scientific achievements and spiritual or metaphysical phenomena to argue that they can be complementary: "strange and often marvelous psychical productions could be exposed as nervous epiphenomena and yet, on the other hand, highlight the unfathomable gifts of the mind, thereby reintroducing spiritual questions to empirical investigation" (5). According to both Neill and Winter, the science and the magic are inextricable in Marsh's contemporary culture; "for historians, these experiments [of mesmerism and hypnosis] can show just how malleable scientific, medical, and intellectual cultures were during this time" (Winter 5-6). Moreover, sexual identity was equally "malleable" at the fin de siècle, as sexual preferences and practices were only beginning to come under the purview of psychological (Krafft-Ebing's 
Psychopathia Sexualis, 1886) and medical (Sexual Inversion by Havelock Ellis and J. A.

Symonds, 1897) study. ${ }^{18}$ Thus, the complementary fields of mesmerism, science, and sexuality formed a cloud of nebulous meaning that Marsh shapes into a vocabulary not only to make space for the possibility of queer desires, but that also allows such desires to slip into normativity via Atherton's happy ending. While the Beetle's transformative and mesmeric abilities are foreign and wild, and she is therefore rejected, Atherton domesticates the same (chemical) transformations and (dominance of) mesmeric abilities to incorporate them into hegemonic norms of science, folding the underlying layers of queer erotics into normativity as well.

\section{Conclusion}

Like a good Victorian novel, The Beetle attempts to conclude by recapturing all stray aberrant behaviors back within normativity—its cautionary bent requires death for the Beetle and reward for Atherton and other main characters. I have already discussed the survival of queer desires in the figure of Atherton, but beyond his magic-in-science, most critics agree that the convenient ending, which purports to clear away threats posed by the foreigner, mesmeric probing, and queer sex, is problematic and, in fact, rather indeterminate. Harris and Vernooy take it a small step further by asserting that "it's certainly possible, and convincing, to read the ending of the novel as in fact destabilizing those conservative hierarchies of gender, race,

${ }^{18}$ The more these fields converged, indeed, the more sex was found at the root of the science of the mind. The Victorian impulse to control and document quickly turned on its head as Freud soon concluded there is an (uncontrollable) unconscious mind that constantly thinks about (unspeakable) sex. 
sexuality, and culture implicit in the imperialist/heteronormative project" (343). The abruptness of the resolution, like the sudden endings of Holt's and Marjorie's narrations, certainly draws attention to both the contrived, convenient feeling of the train accident and the uneasy feeling that the story is not quite finished. The Beetle's death is technically uncertain, the destruction of the Children of Isis is unclear, and the very Victorian triple marriage is marred by several lingering problems. The train accident we are supposed to believe ends the Beetle's life is a clear analogy for the triumph of science and technology over her Egyptian occult magic. But what is left on the train as "evidence" of the Beetle's demise is literally fluid, and we find out that the fluid on the train actually has the last laugh, since science cannot identify it.

Similarly, the description of the destruction at the Temple of the Children of Isis is ambiguous: even Champnell acknowledges that the reports of the "curious subterranean building" are unclear: he uses words like "seemed," "as if," "believe," "erred," and "suggest" (320). He admits that "no scientific examination of the remains took place" and that his theory that it was the very same temple of Lessingham's story is "not a hypothesis which [he] should care to advance with any degree of certainty" (321). The Temple, it seems, is much like the Beetle - mutable, movable, and likely to long outlast technology. ${ }^{19}$ Even its ruins, if these are

${ }^{19}$ Harris and Vernooy present an interesting interpretation: "no causal explanation is offered for the destruction of the underground temple of Isis at Dongola reported in the novel's coda. While one cannot conclusively tie Atherton to the explosion of the temple $[\ldots]$ this certainly seems more than a suggestive coincidence" (351). Attributing the destruction of the temple to Atherton's experiments, whether the poisonous gas or something a bit more explosive, again 
the ruins of the temple, are untested by science, unannounced by news, and unnamed witnesses cannot identify the remains present by gender or species. Though his final sentence on the matter makes Champnell seem entirely confident that his interpretation is the correct one, the preceding paragraphs, describing the actual event, have already established its uncertainty. The triple marriage is at least as problematic as the questionable elimination of the threat posed by the Children of Isis including the Beetle. Most scholars agree that "no matter how tidy, no marriage at the close of a gothic novel can entirely dispel the thrilling dys- (or different) functionality at the heart of gothic" (Haggerty 3). Marjorie remains psychologically damaged and her New Woman persona is entirely undone, and we find that "Paul Lessingham" is a pseudonym. Atherton's marriage to Dora, while at least foreshadowed in the text, seems like an afterthought designed to contain his dangerously aberrant sexuality and her sexual forwardness. Percy, barely even a minor character, is awarded one of Dora's bridesmaids, just to give the story a nice solid number of unions. Methinks Marsh doth protest too much. The convenience and the contrived feeling of especially the last marriage leaves the reader with more questions than answers, and rather than solidifying normative ideals (especially those of gender and sexuality), we are left wondering what happened to the potential we could see in the queer expressions spoken through the languages of mesmerism and Orientalism.

In The Beetle, Marsh uses mesmerism as a language of queer desire: the relationship between the practitioner and subject involve intimate touch and a communion of minds leading to lowered inhibitions and heightened sexual availability. Marsh includes accurate, specific

attempts to uphold the triumph of science over occult magic. It fails because Atherton himself speaks of science in magical terms. 
episodes of hypnosis between the Beetle and various subject/partners to portray the flexible applications of such intimacy and to demonstrate the potential for relationships other than the male/dominant/mesmerist and female/susceptible/subject. The symbolic meanings of the mesmeric touch, trance, and mind control are supported by Marsh's use of Orientalism, which has similar underlying questions surrounding agency, the self and other, and aberrant sexuality. The Beetle's combination of mesmeric and Oriental qualities, along with her ability to bodily transform, make her the terrifying abhuman antagonist. Halberstam says of the gothic monster, "multiple interpretations are embedded in the text and part of the experience of horror comes from the realization that meaning itself runs riot" (Skin Shows 2). Thus, while we can see Oriental and mystical traits distilled in the Beetle, she also contains "riotous" meaning, uncontained and incoherent. She introduces queer desire cloaked in mesmeric trance, but is punished for her criminal uses of her powers and the novel cautions against using hypnotism and condemns aberrant sexuality. Atherton's survival, though, indicates hope for the spark of magic and queer erotic expression. 


\section{Chapter 4: The Aesthetic Marriage of Michael Field}

Variously called "lovers," "life partner[s]," "romantic friends," and members of a "transitional lesbian generation," Katherine Bradley and Edith Cooper wrote together as Michael Field from the early 1880s until their deaths in 1914 and 1913 respectively (Donoghue 8, 27, 29). ${ }^{1}$ Though the fascinating aunt and niece were praised by some in their own time, after their deaths their work spent decades in relative obscurity. Scholarly interest in "the Michaels" has been increasing since the 1970s, ${ }^{2}$ yet Mary Sturgeon's 1922 biography remains the only fulllength study of the women's lives together. ${ }^{3}$ Though Bradley and Cooper focused their energies largely on their dramas and were dedicated to a joint journal that eventually filled 26 volumes, ${ }^{4}$

${ }^{1}$ There is some inconsistency in the spelling of Katherine / Katharine among scholars.

${ }^{2}$ Prominent Michael Field scholars include Emma Donoghue, Holly Laird, Yopie Prins, Marion Thain, Ana Parejo Vadillo, Chris White, and others.

${ }^{3}$ Donoghue's biography is a shorter and very accessible "profile" for the Outlines series, which investigates the "various and often unexpected ways in which homosexuality has informed the life and creative work of [...] influential gay and lesbian artists." Because of its position as part of this series, the biography necessarily highlights the women's relationship as lesbian and, though Donoghue acknowledges contextual conceptions of sexuality that complicate the portrayal of the women as such, it still rings slightly anachronistic.

4 Their journal, unfortunately, has never been published in full. Selections were edited by T. Sturge Moore, their executor, and published as Works and Days in 1933. The full collection was given to the British Library, awaiting a "less shockable generation," and is available on 
renewed attention to their work often centers on their poetry, which reflects their interest in pagan traditions and Hellenism, dedication to aestheticism, their own collaborative writing and living, and, later, their conversion to Catholicism. These themes tie the Michaels closely to others in the current project: like Teleny, their co-authorship and art create a special, mystical bond that elevates their relationship; like Dorian Gray, they are devoted to art for art's sake and channel others; like The Beetle, they explore foreign spiritualities in order to give expression to their sexuality. But beyond bringing together the previous three chapters, Bradley and Cooper demonstrate that the spiritual and sexual intersections investigated here expand past male homosexual desire and past the dominant Victorian form of the prose novel.

While some scholars, most notably Jill Ehnenn and Chris White, have explored the erotic potential of the collaboration between Bradley and Cooper, and others, like Linda Dowling, Stefano Evangelista, and Daniel Orrells have investigated the use of Hellenism as code for aberrant sexual practices, Yopie Prins approaches putting the two together. Like Prins, I argue that Bradley and Cooper's homoerotic relationship is represented in their works via Hellenism and mysticism, first expressed by channeling Sappho but also later in their explorations of Catholicism. Furthermore, the spiritual aspect of their collaboration is part of what unites the women in what I call an "aesthetic marriage," which is strengthened by their physical relationship. ${ }^{5}$ I embrace existing scholarship on the erotics of collaboration while emphasizing

microfilm (Donoghue 144). The figure of 26 volumes is not echoed everywhere, as other sources seem to include bound ephemera in the tally; 26 is the number cited by Works and Days. ${ }^{5}$ Prins simply calls their union an "alternative marriage," accounting for their "alternative" sexuality and artistic collaboration, but not their spiritual bond ("Greek Maenads" 46). 
the role of spirituality via the use of erotic Hellenism. Beyond the erotic and spiritual process of collaboration, their single, masculine pen-name, Michael Field, represents their awareness of and interest in experimenting with gendered norms, genres, tropes, and heterosexual desires while simultaneously uniting their identities and strengthening their queer relationship.

Bradley and Cooper knew each other long before they began writing together, thoughindeed, the niece (b. 12 January 1862) never knew a time when her aunt (b. 27 October 1846) was not a part of her life. Bradley's older sister, "Lissie," was left "perpetually feeble" after the birth of Edith's younger sister, Amy (Donoghue 15). Thus, the care of three-year old Edith and little Amy was largely left to Bradley and her mother (their maternal grandmother). After cancer claimed the life of "Grandma," Bradley cared for both girls, though she bonded especially closely with Edith. As Lissie's health continued to be poor, between her own travels abroad and education Bradley taught her young nieces and lived with the family. Eventually, Lissie and James Cooper both died and Amy married, leaving Bradley and Cooper to live together as they pleased. As Prins succinctly puts it, "The sixteen-year age difference between Katherine and Edith, not quite a generation apart, allowed them to play different familial roles: if initially the aunt was like a mother and the niece like a daughter, gradually they became more like sisters, and then more like lovers, and eventually like husband and wife" ("Greek Maenads" 54). In this way, their generational difference shifted from parent to sibling to spouse as they negotiated a unique relationship based on life-long dedication to each other and art. 
Bradley and Cooper began publishing as Michael Field in 1884 with Callirrhoë and Fair Rosamund, two dramas bound together. ${ }^{6}$ They wrote a total of thirty plays, often bound in multiples of two or three, and eleven volumes of poetry. The scripts were closet-dramas, written almost exclusively to be read rather than acted, and call for a stunning number of actors, props, and elaborate scene changes. The plays also employ the language and style of Elizabethan dramas, so although they had literary merit (and were praised by some of the women's most important contemporaries) they were never meant for wide distribution and did not aim at popularity. In addition to their outmoded style and language, the plays themselves overwhelmingly take as their subjects historical or mythical figures, making them doubly archaic. Their life-long interest in historical figures and modes in dramatic writing reveals the aunt and niece's dedication to interacting with — and making current — different pasts, through which they could depict the struggles or issues of their own time, most commonly questions of women's equality and humanity.

As the dramas of Bradley and Cooper take on historical figures and stories, their poetry reveals a penchant for Classical characters much beloved by writers of all generations. For example, Long Ago expands the translations of Sapphic fragments by Henry Wharton published in 1885 into beautiful explorations of gender, sexuality, and identity that reveal Bradley and Cooper's relationship through the lens of ancient Greece. This small volume of 68 poems was published in a run of only 100 copies in 1889 , to much initial praise (Donoghue $47-50$ ). But unlike their obsession with historical dramatis personae, their fascination with Sappho in verse

\footnotetext{
${ }^{6}$ Prior to this publication, Bradley published a volume of poetry as Arran Leigh in 1875 , and the two women together published their first drama as Arran and Isla Leigh in 1881 (Bickle xxxiii).
} 
was squarely on par with contemporary trends. As T. D. Olverson identifies, the Michaels have an almost direct precedent in Swinburne. ${ }^{7}$ Other poems, similarly based on Classical themes or characters, also reflected general Victorian interest in Hellenism, elaborated on below. Their interest in antiquity gives the women both a way to escape the fin de siècle world of sexual and spiritual malaise and an opportunity to express alternative ideals of sex, art, and religion disguised as history.

Bradley and Cooper lived and worked closely together their entire lives and, although their relationship was not flawless, their unity and devotion (and their dedication to portraying such unity and devotion to the world) demonstrate the power of their nontraditional love. Their collaborative authorship is both erotic and spiritual, as is their use of mythical and Classical figures. This combination of the mystical and the sexual is what gives their poetry strength and is ultimately what unites them in what I call "aesthetic marriage." Such a marriage is dedicated to the joint creation of art for art's sake, as the name implies, but is more than just the unity between collaborators - it is the total harmony between parts that remain distinct enough to act on each other, inspire each other, and challenge each other intellectually and spiritually. In essence, an aesthetic marriage is ultimate Platonic love, an intellectual and spiritual love, enhanced by an erotic aspect of physical desire that leads to not only mental but also physical unity or complementarity. The emphasis on creation and collaboration in art and life sets aesthetic marriage apart from normative marriage; it is, perhaps, what Bradley means when she

\footnotetext{
${ }^{7}$ See Olverson's "Libidinous Laureates and Lyrical Maenads: Michael Field, Swinburne and Erotic Hellenism.”
} 
claims that she and Cooper are "closer married" than the Brownings (Works and Days 16, emphasis original).

\section{Michael and Field}

Many critics speculate on the choice of the pseudonym "Michael Field," though most agree that "Michael" may refer to the archangel, and that the "associations of nature and open spaces" lie behind "Field" (Donoghue 36), though perhaps the surname was chosen just because it sounded good with "Michael" (Sturgeon 27). While the women used "Michael Field" when publishing, they enjoyed the playful application of many nicknames in their private correspondence — both for each other and for their family and friends. ${ }^{8}$ As Emma Donoghue explains, "these silly nicknames had a serious point; [they] were devising a vocabulary to celebrate non-marital but complementary roles they [...] played. Instead of husband and wife, they could be apple and pear" (87). This same name-based "vocabulary" helped Cooper navigate her tumultuous relationship with "The Faun," Bernard Berenson, for example. ${ }^{9}$ So their

\footnotetext{
${ }^{8}$ Nicknames for Bradley included simply "Michael," "Simiorg" or its many derivatives "S," "Sim," "All-Wise Fowl," and "AWF," and its symbol, which looks like a "V" for a bird in flight; and for Cooper, "Persian Puss" and its derivatives "Puss," "P," and "PP." While these nicknames were purely inventive pet-names, Bradley also called Cooper "Henry" and "Henny/ie" after an illness caused Cooper's hair to be cut and her German nurse to exclaim how like a handsome young boy she looked. The nurse, who became entirely devoted to Cooper, began calling her Heinrich (Thain, Vadillo 29).

${ }^{9}$ For more on Cooper's relationship with Berenson, see Vicinus's "Sister Souls."
} 
primary nickname, their pen-name, assigned to their written works and presented to the public, Michael Field, operates as a symbol or "vocabulary" for their unity in art and life.

In addition to helping them define and describe their relations with others, nicknames, particularly Bradley's "Michael” and Cooper's "Henry" demonstrate the women's dedication to gender play even, and especially, in their private interactions. ${ }^{10}$ The use of their masculine penname for publications, then, was an extension of their private exploration of gender and relation: the pen name was, perhaps, more true for them than their own given names. In its masculinity, the women found the authority and comfort their feminine names lacked, and in its single, though compound nature, they found an expression of their unity. They were dismayed to find that it was their friend and idol Robert Browning (nicknamed, privately, "the Old") who had let slip to the press that Michael Field was two women. Bradley wrote to him that "the revelation of that [dual authorship] would indeed be utter ruin to [them]" and that "[they] have many things to say that the world will not tolerate from a woman's lips" (Works and Days 6). Their response to being outed reveals that they were not only playing with names, but were keenly aware of the ramifications of pen-names in literary production — in regards to both gender and their collaboration. While their response to Browning reveals the truth also recognized by women

\footnotetext{
${ }^{10}$ Vicinus relates an interesting anecdote about a time while Cooper was sick when she compared herself to Antinoüs, famous lover of the Roman emperor Hadrian ("Adolescent Boy" 93). This use of another name was not only cross-gender, but explicitly indicated homoeroticism, as I discuss in Chapter I on Teleny. For more on Antinoüs and the fascination he held for Victorians, see Sarah Waters, “"The Most Famous Fairy in History’: Antinous and Homosexual Fantasy."
} 
writers using masculine pseudonyms like George Sand, George Eliot, and Vernon Lee, ${ }^{11}$ The Michaels were also concerned about the reception of their duality.

A year and a half after explaining to Browning the rationale for their conscious decision to present the unified, masculine pen-name, Bradley wrote to Havelock Ellis about her collaborative process with Cooper:

As to our work, let no man think he can put asunder what God has joined. [...T]he work is perfect mosaic: we cross and interlace like a company of dancing summer flies; if one begins a character, his companion seizes and possesses it; if one conceives a scene or situation, the other corrects, completes, or murderously cuts away. (qtd. in Sturgeon 47)

Her insistence on using the masculine pronoun emphasizes the deeply meaningful pseudonym and simultaneously highlights the true unity of their writing as Michael Field. This "flirtatious, angry dance" of collaboration is, significantly, prefaced by a warning based in the language of the Marriage Service which emphasized its "sacred and indissoluble bond" between the women both in authorship and in life (Donoghue 34, 35).

Collaboration was a way of life for Bradley and Cooper, but as a mode of authorship it was viewed with suspicion. Sturgeon muses, "something in the fact of a collaboration was obscurely repellent" (29). Others are more explicit: many propose that the "obscurely repellent" feeling Sturgeon identifies is a sexual one, and that collaborative writing indicated an erotic and/or romantic relationship. Sturgeon's 1922 biography neatly dances around any description

\footnotetext{
${ }^{11}$ Indeed, another point Bradley makes in this letter to Browning is that his revelation meant that he is "robbing [them] of real criticism, such as a man gives a man" (Works and Days 7).
} 
or specificity about the women's relationship beyond their writing, likely because of its context (an era fearful or condemning of alternative sexuality) and because for women, private citizens often alone in each other's company, romantic friendships were common. ${ }^{12}$ But Bradley and Cooper's dedication to each other, coupled with their united authorial voice, gives scholars a fuller picture of the nature of their relationship. They were life partners and passionately devoted to each other. They used the language of marriage and mystical union to describe their partnership. Their poetry, for and about each other, abounds with the sensual and sexual. Thus, it requires very little imagination to see that the Michaels were indeed joined in an erotic collaboration of writing and life.

As Wayne Koestenbaum has argued for men, literary collaboration can be a mode of ‘joining selves' and creating "bonds" between men who shared a "secret life" of homosociality bordering on homosexuality (1-3). He says, "collaborators express homoeroticism and they strive to conceal it," creating the "double-talk" of his title (3). Though Koestenbaum specifically takes men as his subjects, much of his work can be applied to women's collaboration and the Michaels. To adapt his main premise, "[Wo]men who collaborate engage in a metaphorical sexual intercourse, and the text they balance between them is alternately the child of their sexual

${ }^{12}$ London acknowledges that while Sturgeon was operating within her own contextual constraints, even still it is difficult to know with certainty the extent of Bradley and Cooper's physical relationship. She says of Michael Field and other women collaborators, "their lives, like their texts, were [...] wrapped up in each other, but their relationships were not easy to define in terms of the erotic. The details of their lives thus reinforce the impression that these partnerships existed somewhere between the faintly scandalous and the quaintly domestic" (5). 
union, and a shared [sex object]" (3). The "flirtatious, angry dance" described to Ellis above is just such a metaphorical erotic encounter; Bradley describes their collaborative process as a mad crashing together of selves, a euphoric editing process of "possession" and "completion." At the same time, though, we can see in the language Bradley uses that Koestenbaum's "double-talk" is also in effect, since to "cross" and "interlace" requires separate selves - indeed, the language is inherently doubled in its "one" and "other" structure. Bette London uses the terms "crosswriting" and "cross-identity" to describe the similar features of women's collaboration. Just as Koestenbaum argues for men, London says that “the discourse that surrounds women's joint writing has inevitably turned on transgressive sexuality, introducing the specter of lesbianism at the site of women's textual productivity" (64). As London and others are careful to note, theories of men's literary collaboration do not precisely translate into discussions about women collaborators, but the core implications of erotic partnering, whether metaphorical or literal, remain.

Jill Ehnenn's Women's Literary Collaboration, Queerness, and Late-Victorian Culture is devoted explicitly to women's collaborations of the time, and she highlights the sexual aspect of the collaborative process and the individual partnerships she examines. The Michaels, like other women collaborators, "spoke of their partnerships in ecstatic, fluid, eroticized terms" (Ehnenn, $W L C 2$ ). Indeed, the way Ehnenn describes the co-writing process echoes the way Bradley described it to Ellis above, a sort of dance of completion and unity; Ehnenn says, "writing with a lover — getting work done — in a rhythm of conversation that finishes each other's sentencesthoughts flying between you so you each seem part of the other. It would be...well, like sex" (WLC 2, emphasis original). This "metaphorical sexual intercourse" Koestenbaum identifies is a central part of Ehnenn's discussion, and it becomes clear that the sex slides off the page and into 
reality for Bradley and Cooper. But I argue that the metaphorical sex is just as important as the potentially literal erotic relationship between the women; they have a consummated marriage of minds. The text thus becomes more than their child or sex object as Koestenbaum posits, but also the product of a mutual orgasm, a "coming together" of minds (Ehnenn, WLC 5). London agrees, saying, "Like other women collaborators, [...] traditional nurturing bleeds into total fusion, where the union of minds in creative work calls up a vision of the joining of bodies" (67). Koestenbaum, London, and Ehnenn each explore a different aspect of the erotics of collaboration, but the concepts dubbed "double-talk" and "cross-writing" indicate that collaborating itself takes multiple things (generations, people, voices, writing hands) and makes them one. Koestenbaum speaks of "joining" and "bonding," Ehnenn talks of "coming together," and London says collaboration culminates in "total fusion." Bradley and Cooper insist on complete unity, which can be extended from their writing into their erotic relationship, but simultaneously emphasize their total complementarity—-their ability to complete each other, editing, cutting, adding — which necessarily requires that they be two.

The seemingly contradictory duality in unity is encompassed and signified by their pen name, discussed above. Michael and Field become Michael Field in fact as well as name. Beyond their collaboration, it also created a "polymorphic gender [which was] a sign of their remarkable unity of reason and passion" (Vicinus, "Sister Souls" 339). ${ }^{13}$ This unity of individuals in art, mind, and body, is what I call "aesthetic marriage." Their collaboration, the united face they presented to the world, and their spiritual natures, discussed below, result in a marriage of minds based in aesthetic, intellectual, and spiritual love and amplified by the

\footnotetext{
${ }^{13}$ Again, we can see the "double-talk" of the poly- and "unity" in Vicinus's formulation.
} 
metaphorical erotics of collaboration and literal physical erotic connection. The emphasis on creation and collaboration in art and life sets aesthetic marriage apart from normative marriage. Their singular pen-name is thus a symbol of their entire union: it recasts their gender, which freed their art; it unites them into a single identity, which reflected their dedication; and it was used to publish their works, which tied their artistic endeavors inherently to their relationship and life. The union of "Michael" and "Field" into a single, compound name also represents the metaphorical and physical 'coming together' of Bradley and Cooper — their mutual textual orgasms reaffirming their bond with each new written work.

There are two important precursors to my term aesthetic marriage as directly applied to Michael Field: first, Ehnenn calls Bradley and Cooper "poet-lovers” numerous times in "Looking Strategically: Feminist and Queer Aesthetics in Michael Field's 'Sight and Song."” For Bradley and Cooper, as for all aesthetic marriages, the poetry requires the love, and the love requires the poetry. Ehnenn's term is also interesting because it is compound, hyphenated. "Poet-lovers" thus participates in the same interesting doubling as the Michaels do themselves, being comprised of two things, unified. But Ehnenn's "poet-lovers" does not, in and of itself, account for the dedicated spiritual bond between the women the way I claim "aesthetic marriage" does. The second direct precursor is found in Vicinus's "Sister Souls" article, which identifies Berenson instead of Bradley as Cooper's "sister soul." Vicinus describes the fallout from Cooper's infatuation: “without Bradley, Cooper's queer desire had no reality; without art, it had no substance" (331). Based on their diary entries at the time, Vicinus concludes, "for Bradley their art and love were the same" (340); in this way, Bradley realized that she was part of an aesthetic marriage with Cooper and recognized its characteristics through their temporary reallocation to Berenson. Though Vicinus thus incorporates "queer desire," "art," and the 
spiritual connection in the word "soul," the term itself is applied to Berenson and the familial "sister" formulation of the bond between Bradley and Cooper is drastically inadequate. Though both "poet-lovers" and "sister souls" indicate that other scholars are investigating the multifaceted relationship between the Michaels, I do not believe they go quite far enough to incorporate sexual love, spirituality, and art.

Bradley and Cooper's relationship was not without its troubles, though, and their bond was tested by an on-again-off-again infatuation Cooper had with Berenson, as Vicinus indicates. ${ }^{14}$ Donoghue sums up Cooper's decisive return to Bradley: "What she [Cooper] seems to have sought was a unique, mystical, platonic friendship" (70). Having not found its fulfillment in Berenson, Cooper realized that her aunt, collaborator, and life partner had always been her spouse in aesthetic marriage - extending beyond "unique, mystical, and platonic friendship" to include erotic collaboration, artistic creation, and unity. "Platonic" here is worth a brief exploration of meaning. Aesthetic marriage, in my formulation, includes at least metaphorical erotic collaboration - the mind-sex of meetings and joinings of artistic mutual orgasm. But common uses of "platonic" describe relationships which specifically exclude sexual intercourse. ${ }^{15}$ Aesthetic marriage, then, is built on the concept of a perfect harmony between

${ }^{14}$ Ultimately, Cooper chose Bradley over Berenson for a number of reasons, but many scholars argue that it was mainly because his heterosexual relationship with Mary Costelloe foreclosed on his androgynous appeal, he became increasingly insensitive and negligent toward the poets, and was busy with his own work.

15 The OED includes an especially funny and noteworthy example of usage from Ada Cambridge in 1905: "What is known as a platonic friendship is generally nothing of the kind." 
individuals, a friendship so deep and fulfilling that sex does not need to be involved, and yet sex is involved. The seeming contradiction in a consummated platonic friendship is what makes aesthetic marriage unique. Bradley and Cooper were indeed united in platonic ideals of art and life, perfectly aligned intellectually and spiritually and physically, erotically. Indeed, other permutations of Platonism in fact indicate (homo)eroticism, rather than precluding it. For example, Evangelista explores the fin de siècle fascination with aesthetic Platonism and its links to homosexuality, saying that "aesthetic Platonism carries with it a strong positive energy: it is the belief in the possibility of a radical reinterpretation of homoerotic desire, no longer as a sexual perversion but as a marker of genius" (“Lovers and Philosophers” 243). Evangelista's evaluation of the interest in aesthetic Platonism for men like Pater, Wilde, and Symonds centers on these concepts of "positive energy," "homoerotic desire," and literary "genius." These are also the foundation of an aesthetic marriage, a transcendent unity in spirit, art, and sex.

\section{Michael, Field, and Sappho}

Victorian Hellenism

The great figures of Victorian Hellenism and alternative sexuality, Symonds, Pater, and Wilde, intentionally promoted Hellenism as a "homosexual legitimation strategy" (Dowling 121). Linda Dowling's foundational work Hellenism and Homosexuality in Victorian Oxford establishes the multifaceted connections between the rise of Hellenism, especially through Greek language education, and a subculture that increasingly examined, evaluated, and even participated in homosexuality. Dowling proposes that men like Symonds, Pater, and Wilde were particularly invested in promoting Hellenism as an "alternative to Christian theology" which developed "a homosexual counterdiscourse able to justify male love" (xiii). She describes this 
movement: "the specific effect of the continuous translation of Christian into Hellenic terms at Oxford was to bypass the ancient religious objections to homosexual behavior-now seen as a matter of faith or taboo fading along with the older and insufficient notions of Christian orthodoxy and ethics" (78). The work within the academy to spread Hellenism and Greek instruction was thus aimed at facilitating acceptance for homosexuality via alternative spiritual/religious approaches contained within Greek Classics. This allowed Victorians who were attempting to navigate a society unfriendly to same-sex desire to rely on an established precedent, layering or re-producing aspects of the ancient generations in the modern world. Though Dowling focuses on the male leaders of the Hellenistic movement, necessarily at the forefront because of their prominent public positions in the academy and as writers, Bradley and Cooper also deeply immersed themselves in the Hellenism of the fin de siècle and its complementary homoerotics. Bradley studied Greek during her time at Newnham College, and later convinced Cooper to learn the language as well (though she preferred Latin). ${ }^{16}$ The Michaels were fascinated by ancient Greek literary figures, and brought them to life in several of their early plays, including Bellerophôn and Callirrhö̈. Through the majority of their work up to their conversion to Catholicism in 1907, their devotion to Hellenism and, in particular, Bacchanalia, "presented Michael Field with a philosophical and spiritual resource, through which they could explore such subjects as religion, power, identity, sexuality, and gender" (Olverson, Dark Side 112-3). Bradley and Cooper's particular brand of Maenadism was, indeed, part of a "spiritual multiplicity" that was flexible and wide-reaching (Olverson, Dark Side 114).

\footnotetext{
${ }^{16}$ And, as Evangelista points out, "Learning Greek in women could be construed as an act of gender subversion" (British Aestheticism 10).
} 
Evangelista explains the women's sincere dedication to pagan worship, which they used to create space for their own alternative ideologies and sexual desires in the late Victorian years:

Bacchic aestheticism was not only a literary practice for them, but a way of conducting their daily life, as is testified by the widely noticed eccentric practices recorded in their letters and diaries: their private mythology of wine, the Bacchanalian dances performed to celebrate the arrival of good news, the erection of an altar to Dionysus in their garden and of a 'Bacchic library' in their study, in which they collected all works of literature that made use of the Dionysian theme. (British Aestheticism 123)

T. D. Olverson, Prins, Evangelista, and others all examine the women's Maenadic dedication to Dionysus and their use of ancient rites and religions to express their aestheticism simultaneously with their romantic and erotic feelings for each other. Thus, just as Dowling argues for many men involved in the promotion of Victorian Hellenism, Michael Field found their Greek mode to be useful in both cloaking and legitimizing same-sex desire. ${ }^{17}$ Using this "sophisticated counterdiscourse, which is both inclusive and positively subversive" was incredibly successful for the poetry of Michael Field because it gave them a framework and a vocabulary with which to explore and describe their own spirituality, creativity, and desire - precisely the characteristics that also define their aesthetic marriage (Olverson, Dark Side 10).

\footnotetext{
${ }^{17}$ Importantly, Prins describes the paganism of Michael Field using much the same language as Dowling, saying it is a "feminine counterdiscourse" and that "in the figure of the Greek maenad they found an imaginary alternative to the Victorian spinster" ("Greek Maenads" 46).
} 
Bradley and Cooper were dedicated to Dionysian rites as a vibrant, active, ecstatic expressions of spirit, life, and love, and they also used other Greek figures in the plays mentioned above and in Long Ago. This collection of poems uses Sappho's Greek fragments and expands them into lyrical explorations of gender, sexuality, and identity that reveal Bradley and Cooper's aesthetic marriage through a Classical lens. "Michael Field," the unified and male author, thus takes on another identity in addition to Bradley and Cooper-adding Sappho to their collaborative writing includes her in their eroticized writing process and unites their pagan voices in poetic praise of the divine. Just like the male Hellenists focused on the potential of Plato, Sappho gives the women a code through which they could express their devotion in writing. Not only are the poems of Long Ago sensual and occasionally openly sexual, they are also often concerned with art, education, and the divine, and the relationships or connections between the aspects. Thus, the addition of Sappho as the third voice in Long Ago reinforces the concept of aesthetic marriage in several ways. First, the objects of Sappho's desire are both men and women, which highlights the aberrant nature of a flexible sexuality, expressed by Bradley and Cooper as an inter-generational same-sex love. Second, Sappho was herself an artist, as a writer and an educator, reinforcing the central importance of artistic creation and collaboration to aesthetic marriage. Finally, Sappho is a figure directly out of the Hellenistic tradition that shifted from Christian to pagan spiritual beliefs. The layering of erotic desire, artistic impulse, and the spiritual aspect create aesthetic marriage for the women, a bond which cements their relationship beyond normative matrimony. 


\section{Sapphic Eros}

Orrells describes this first point, the tangle of gender and gendered desires, in Sex: Antiquity and its Legacy. While cautionary constructions of the lesbian Sappho (as opposed to merely Sappho from Lesbos) began circulating along with other images of tribades, "the image of Sappho as a pure and chaste Victorian schoolmistress" was also carefully presented to contemporary readers (Orrells 129). Both characterizations of Sappho coexisted in part because nineteenth-century German translations of Sappho used primarily masculine pronouns to give Sappho a heterosexual "wholesome image" which was then perpetuated by Symonds, ${ }^{18}$ while at the same time "male writers could not help but appropriate Sappho's voice to express their own desires" (Orrells 129). In this way, Sappho's fragments, initially framed as harmless affection between a teacher and her pupils with erotic desire only for men, were commandeered by male writers to write of their desire for women, thereby reflecting the desire for women back onto Sappho. Sappho's own voice supports both readings, though, especially after the various original pronouns were restored and included in the much-circulated 1885 edition by Wharton of fragments, biography, and reimaginings (Orrells 145). The restored pronouns reveal that Sappho did desire men (or $a$ man-Phaon), but was also attracted to her female students. Thus, when men would use her voice to speak of love of women, they were simultaneously ignoring her desire for Phaon (which would have been same-sex desire for male authors), and ignoring the same-sex desire implicit in using the female voice of Sappho to speak of love of women. As an

\footnotetext{
${ }^{18}$ Orrells and others are careful to distinguish between Symonds's support of pederasty and his abhorrence of lesbianism. Interestingly, the age difference between Bradley and Cooper made it easy to "cast [Cooper] in the role of the young initiate" (Vicinus, "Adolescent Boy" 93).
} 
unintended consequence, the male authors straightened Sappho's own same-sex desires and queered the heterosexual desires that they were intending to portray. Indeed, Orrells says, "Sappho offered a more nuanced opportunity to think about the relationship between heterosexual love and female same-sex sexuality" (Orrells 147). These exploratory constructions of Sappho and her sexuality, before the poetry of Long Ago, already bring her into the Victorian literary space. The differences between her carefully-crafted personas also reveal that she was already being used as a coded way of expressing and navigating the sexual, textual, and spiritual Victorian scene. Uniting these various aspects by channeling her voice, Bradley and Cooper outline their own personalized alliance.

Michael Field adds an even more complex layer of gender to the re-writing of Sapphic fragments because, of course, they were two women writing under a male pseudonym who did indeed have (female) homoerotic desires. In Long Ago, they are women writing as a man writing in the voice of a woman about love of women and men. The complex fluidity of gender in the collection of poems queers Bradley and Cooper's gender(s) to the extent that they are meaningless - to fix the writer(s) of Long Ago as only male or female is only possible if numerous other layers of authorship are disregarded. I argue, then, that the gendered identity that emerges is the one that Bradley and Cooper choose for themselves, citing the importance of their consciously self-formed identity. ${ }^{19}$ Their choice of the singular and male pseudonym,

${ }^{19}$ Certainly, it could be argued that the cloud of gender performances leaves Bradley and Cooper simply genderqueer or agender at this point, but those conceptual identities were not available to the women. Though they perhaps "tried to shrug off gender" instead of thinking of themselves as masculine women or feminine men (Donoghue 37), I argue that their choices about their own 
encompassing two female figures, adds Sappho as a third figure. Sappho thus helps to express the sexual element of aesthetic marriage in that the addition of her authorial voice, with all its implications, exposes the alternative nature of the gendered desires felt by Bradley and Cooper.

Beyond the complex gender of the author(s), the genders of the sexual objects of the poems are various. There are many poems that feature Sappho's unrequited love for Phaon, for example III, in which Phaon's love is compared to forbidden honey, or V, when Sappho laments her lost virginity as a hyacinth trampled by a man. Sappho's desire for Phaon, or the lessons she teaches her students based on the knowledge she has gained from her unrequited love, recurs throughout the volume. XXXIII, for example, asserts that falling in love with a man is a bad idea and that it is much better for Sappho to remain devoted to her (female) students. Thus, heterosexual desire is interspersed with sensual admirations of other women. In the first stanza of XXXV, Sappho invites one of her favorite students to bed:

Come, Gorgo, put the rug in place, And passionate recline;

I love to see thee in thy grace, Dark, virulent, divine.

This short, four-line excerpt contains a feverish concentration of erotic desire in the rapid-fire words "passionate," "recline," "love," "grace," "dark," "virulent," and "divine;" the praise of Gorgo's physical body and the sexual longing it inspires in the speaker are obvious.

gendered identity indicate a double gender rather than no gender. Prins, White, and Thain all write on Michael Field as a "Tiresian" poet, and certainly the inclusion of the Tiresias myth in Long Ago is noteworthy. 
Even more specifically, in XXVII she appreciates a student's breasts: "But when Mnasidica doth raise / Her arm to feed the lamp I gaze / Glad at the lovely curve" (lines 15-17), and LVIII is similarly an ode to breasts, as Sappho admires "warm flesh":

What are these roses like? Oh, they are rare,

So balmy pink

I will not shrink

Them to the Graces to compare,

When in gay dance the laughing triad link, When the round, lifted arms are bare,

And just about

The elbows' pout

The warm flesh glows

Into a flower, incomparable rose:

Such fluctuating stealth

Of light doth interfuse

Their virgin health,

In its soft buoyance, as indues

You, O ye roses, with your heavenly hues.

Sappho's admiration for women's bodies is clear: the "balmy pink" softness and rounded limbs compared to roses moving in a "gay dance" are as delightful and enchanting as the divine Graces. ${ }^{20}$ Rather than praising a specific student (like Gorgo or Mnasidica, above), this poem admires all breasts as "incomparable roses" with "soft buoyance." Furthermore, XLIII reads very much like an ode to the vagina ("Secluded from man's view / A little cave that cleaves / The rock with fissure deep. / Worshiped with milk and oil, / There dwell the Nymphs" and so on [ln. 5-9]), precluding the more chaste reading that the speaker(s) in Long Ago merely admire beautiful bodies in general.

\footnotetext{
${ }^{20}$ As I explore briefly below, "triads" were of special interest to Field; in this case the Graces echo the grouping of Bradley, Cooper, and Sappho.
} 
The clear references to a very physical same-sex love, compared alongside her many laments at lost virginity to Phaon indicate that Sappho was sexually attracted to various partners. The inclusion of the Tiresias poem is further evidence of Bradley and Cooper's exploration of gender and sexuality and a mirror of their own indefinite gender. ${ }^{21}$ Like Tiresias's affirmation of women's pleasure, Sappho's warnings against loving men reflect the choice of Bradley and Cooper to love only each other, since they are the actual authors of the extended poems. Their use of Sappho's voice legitimizes this choice and the imagined purity of women only loving women strengthens their bond.

Beyond heterosexual and homosexual desires, the lyrics of Long Ago also include a few poems about marriage (XXII, XLII, and XLVII). More specifically, Sappho takes on the role of surrogate groom to admire and praise her students, placing herself in the masculine role and projecting her same-sex desire into the normative framework of marriage. Tribadism, though often considered merely practice for marriage and heterosexual coupling, is instead held as the ideal in Field's Sapphic lyrics. Each of the marriage poems ends before the wedding takes place, leaving Sappho in the place of the groom and foreclosing on heterosexual consummation. The resulting suspended pair-Sappho and a female student—represents the marriage-like dedication that Bradley and Cooper shared. Sappho provides the vehicle and the voice for the idea of a dedicated women's same-sex relationship, coming from the distant past to help Bradley and Cooper describe and validate their own aesthetic marriage in the fin de siécle.

${ }^{21}$ See White's "The Tiresian Poet: Michael Field" in the 1996 edition of Victorian Women Poets: A Critical Reader edited by Angela Leighton. 
Sappho's Creative Impulse

As an artist, writer, and teacher, Sappho also adds to Bradley and Cooper's aesthetic marriage in the act of writing itself. Going beyond what Koestenbaum, London, and Ehnenn discuss about the erotics of collaboration and its inherent multiplicity in unity, Prins addresses the addition of the Sapphic voice and explains that Sappho herself is a "composite image," subjected by Wharton to "multiplication" of versions, which leads to further "poetic doubling of Sappho by Michael Field" (Victorian Sappho 75). These layers of identity and authorial voice are, like all of their writing, embodied by the name Michael Field, which shares the cover of Long Ago with the name Sappho. ${ }^{22}$ For these poems, then, the multiplicity of genders, sexualities, and authors is united and indicated by the author's signature(s). Based on the theories of collaboration discussed above, Bradley and Cooper are linked erotically (metaphorically in their coauthorship or literally in their physical sexual desires) to Sappho, and they also share a drive to write or create which is vital for aesthetic marriage. Their names' appearance together on the title page link them all together in the co-creation of art.

For Long Ago, the addition of the third collaborator adds a layer of creativity and aesthetic production, cementing the bond between Bradley, Cooper, and Sappho. Many of the poems in Long Ago either feature Sappho as a singer, lyre player, or poet, emphasizing her role as a creative artist. In the first two stanzas of XXII, she welcomes young students to gather and listen to her wisdom and music - presented as one and the same:

They bring me gifts, they honour me,

Now I am growing old;

And wondering youth crowds round my knee,

${ }^{22}$ For a more in-depth analysis of this fascinating cover, see Prins, "The Double Signature" in Victorian Sappho. 
As if I had a mystery

And worship to unfold.

O gather round me, golden youth,

For justly ye divine

I am your prophetess forsooth,

And ye shall learn love's very truth

Who to my lyre incline.

These "wondering youths," of course, include Victorians who had revived interest in the “prophetess," including Bradley and Cooper. But to Michael Field, it is not just "as if” Sappho has wisdom to bestow - the women do "divine" the truth about love by witnessing and extending Sappho's art and “inclining” to her lyre. The connection between Sappho and her students or followers, which can be read to include Bradley and Cooper each time, recurs in several of the lyrics of Long Ago; in XXVI for example, Sappho says she loves her "virgin train" that sits and learns, "violet-weaving at [her] knee" (lines 2, 7).

While Bradley and Cooper construct their own role as her descendants, they also ventriloquize her, uniting all three voices. For example, the first stanza of XXXIV seems to give us a clear picture of Michael Field's entire publishing philosophy via Sappho's own artistic performance:

"Sing to us, Sappho!" cried the crowd, And to my lyre I sprang;

Apollo seized me, and aloud Tumultuous I sang. I did not think of who would hear; I knew not there were men who jeer; Nor dreamed I there were mortals born To make the poet's heart forlorn.

By writing outmoded closet-dramas and poetry published in limited runs, Bradley and Cooper certainly don't "think of who would hear," and after some early positive reviews, some men did indeed "jeer" at them. But, "tumultuous," excited, enthusiastic, they continued answering 
Apollo's call. Thus, Sappho as an artist provides an important device for Bradley and Cooper, through which they explore poetry, performativity, and reception. Sappho is simultaneously a feminine role model, teacher, and collaborator to the Victorian women, who see in her a mentor and an artist divinely inspired, but also an equal with and through whom they can write. Just as Sappho's own role as a teacher bleeds into her role as a lover in her constructed mythos, Bradley first mothers Cooper, then becomes her partner, highlighting the role of art and education in their relationship(s). In this way, the aunt and niece rely on the voice of Sappho to explain and reveal their own artistic origins and philosophies and the importance of art in love and love in art - the central tenet of aesthetic marriage.

Resurrected Paganism

The overwhelming presence of erotic attraction and artistic endeavor in Long Ago are completed and complemented by the paganism in the poems. The inherent Hellenism of the collection seeks to make room in Victorian culture for new expressions of desire and art. Social conventions based on religious convictions could not accept same-sex desire, so Bradley and Cooper turned to Classical modes that would. The women focused on the religious or spiritual aspects of the Hellenistic movement discussed above to highlight the different possibilities for expressions of same-sex love, using the paganism as a code or vocabulary to discuss their taboo dedication to each other. Their use of paganism in the Sapphic poems was not just literary, though, as the women seemed to sincerely take on the role of ecstatic maenads: Evangelista says, "Bradley and Cooper embraced the total claim of the Dionysian cult with its glorification of sexuality and intoxication, its revolutionary energy, radical aestheticism, and virulent hostility towards protestant Christianity" (British Aestheticism 123). Representations of pagan worship in 
Long Ago thus simultaneously represent Bradley and Cooper's dedication to alternative religious practices and celebrates their same-sex desires that normative ideologies would not admit;

Evangelista explains, "their modern paganism is simultaneously an authorial identity and a revolt against the social and religious conventions of the time" (British Aestheticism 115).

Paganism as an aspect of the Hellenistic movement was thus doubly productive for Michael Field: as a code or vocabulary, pagan characters and acts of worship allowed the women to disguise their erotic desires in Classical symbolism, and as a lifestyle of celebration and ecstasy, pagan worship united the women in spirit and love. These two complementary uses of paganism are found throughout Long Ago: In XVII, for example, the code of pagan ritual surfaces as the interactions between Sappho and her students while they dance and worship ancient gods, Sappho playing the music that accompanies the younger women. Such symbolism allows Bradley and Cooper to explore the female gaze as Sappho watches her students dancing, and involves the movement and intertwining of bodies in a religious rite, disguising the otherwise notably sexual desires aroused by 'stirring' pale "limbs" in dance:

The moon rose full: the women stood As though within a sacred wood Around an altar - thus with awe The perfect, virgin orb they saw Supreme above them; and its light Fell on their limbs and garments white. Then with pale, lifted brows they stirred Their fearful steps at Sappho's word, And in a circle moved around, Responsive to her music's sound, That through the silent air stole on, Until their breathless dread was gone, And they could dance with lightsome feet, And lift the song with voices sweet.

These white-robed virgins, dancing around an altar in a sacred, private place, singing while Sappho plays the lyre, create a symbolic all-female world where they are free to worship the 
moon. The second half of the poem reinforces the idea that such devotion to Artemis ("perfect" and "supreme") represents a rejection of men and heterosexual intercourse, as Sappho begs Artemis to return her virginity and restore her pure pagan faith. The virgins of the passage quoted here, on the other hand, can "dance with lightsome feet" because they have pure faith and bodies untouched by men. Bradley and Cooper, in a parallel rejection of men, use the pagan practices of Sappho and her time to explore the potential of a homosocial women's experience while also hinting that part of its success is only ever knowing sexual pleasure at the hands of other women. Using the vocabulary of pagan worship was thus productive for the women's poetry and their interest in exploring their own desires through their work.

Moreover, the pagan celebrations of Michael Field's poetry were productive for their own lived religious experiences. A number of poems in Long Ago include pagan images and actions that seem to bear little influence on the message of the poem, but set the stage and establish a distinctly Hellenistic atmosphere. Reworking Sappho means working within her own context of spirituality, but for Bradley and Cooper paganism was much more than just maintaining authenticity for the lyrics. Louis explains the appeal, saying, "the exaltation of the [Greek] Mysteries became a way to celebrate the sacredness of this life, of sexuality, and of the life force" for Bradley and Cooper (2). The fourth quatrain of XII demonstrates such joie de vivre at the onset of spring:

The shepherd's pipe is heard, The villages are stirred To shout the wine-god's praise, And jest in rural ways.

This beautiful celebration of spring includes not only an ode to plants that "bud anew," but a specifically pagan form of worship in honor of the new life and renewed love (ln. 10). Olverson reiterates the importance of such imagery, saying, "Michael Field celebrated and venerated the 
Greek gods with Bacchic enthusiasm. [...] Their identification with ancient Greece was, in fact, not only professional but personal" (Dark Side 111). The Bacchic celebrations, reminiscent of the ones Bradley and Cooper enacted in their personal lives, include sensual dance and the music of the lyre, thereby joining together sex, art, and spiritual bliss.

\section{De-crypting Sappho}

Poem LIV in Long Ago also describes pagan vernal festivities, this time including Sappho's students, and we can imagine Bradley and Cooper each taking on the various roles of admiring and admired, singer and listener: the poem embodies both their literary uses of paganism as productive in encoding desires, and is an echo of how they allowed paganism to enrich their own lives. The poem furthermore highlights Sappho's same-sex desire and her role as artist:

A down the Lesbian vales, When spring first flashes out, I watch the lovely rout

Of maidens flitting 'mid the honey-bees

For thyme and heath, Cistus, and trails

Of myrtle-wreath:

They bring me these

My passionate, unsated sense to please.

In turn to please my maids, Most deftly will I sing

Sappho's students "please" her "unsated sense" and she gladly reciprocates to bring them pleasure as well: their "lovely rout" of pagan celebration is complemented by her art of "deftly" singing. Thus, we can see that the pagan mode helps cement Bradley, Cooper, and Sappho’s voices, desires, and art together. Bradley and Cooper unite their own voices with Sappho's to 
complete her fragments across the centuries, using her established personas to explore their own views and expressions of same-sex desire, artistic production, and paganism.

Using Sappho as both cloaking and legitimizing strategies, Bradley and Cooper are at liberty to explore the potential of implementing feminine Hellenism. First, as discussed above, the objects of Sappho's desire are both men and women, which highlights the aberrant nature of such a flexible sexuality, experienced by Bradley and Cooper as an inter-generational same-sex love. Second, Sappho was herself an artist, reinforcing the central importance of artistic creation and collaboration Bradley and Cooper shared. Finally, Sappho is a figure directly out of the Victorian Hellenistic movement described above that shifted from Christian to pagan spiritual beliefs as a way of changing the moral conversation surrounding same-sex desire, which was productive for the poets in their art and life. The layering of erotic desire, artistic impulse, and spirituality create aesthetic marriage for the women, a bond which cements their relationship beyond normative matrimony.

The addition of Sappho as the third voice in Long Ago allows for the transmission of ideas that validates and legitimizes the same-sex, intergenerational relationship between the aunt and niece. Sappho not only gives the women the vocabulary and symbols to express their love, but also gives them the artistic and spiritual framework on which to do so. Her fragments allow Michael Field to explore "the concept of 'extension', with its simultaneous evocation of space (from short fragment to full poem) and time (from antiquity to modernity)" (Evangelista, British Aestheticism 102). As the poet-mother, Sappho takes on her role of teacher and model for Bradley and Cooper, just as Bradley does for Cooper when she is young. In LVII, Sappho herself calls on her "mother muse" when other inspiration fails, and because her "mother muse" 
can sympathize with Sappho's lament of unrequited love and lost virginity. Similarly, Bradley and Cooper call upon Sappho as their poet-mother to sympathize with their same-sex love.

Just as Bradley and Cooper's familial relationships changed over time from parent to spouse, so the relationship between Sappho and Michael Field is also one that created poetic offspring. Sappho's fragments provided some of the genetic material, while Bradley and Cooper allowed the lines to gestate into full lyrics. Their union results in a beautiful hybrid volume of poems which are both ancient and modern. Since Koestenbaum asserts that literature is the child of erotic collaborative coupling, it is easy to see that Sappho, Bradley, and Cooper are indeed (metaphorically) erotically linked. The poem-children of Long Ago speak to the collaborative power of women working together to (re)produce art. These three distinct artists unite in a single voice to (pro)create poetry, the offspring of Bradley and Cooper's aesthetic marriage.

\section{Interlude: Michael, Field, and Whym Chow}

For Michael Field, the life and death of their dog Whym Chow marks the transition from Maenadic pagan revel-worship to solemn Catholicism. In their journal, Cooper wrote of the Skye terrier after his death: "our own Whym Chow, the light of our love, of our hearts, our spirits, our religion, our imaginations - Whym Chow, our Eastern Joy!” (qtd. in Thain, 185). The dog had an immeasurable impact on their lives and, as their "imaginations," he impacted their work as well. Indeed, from his death in 1906, the women kept a private, ongoing volume of poetry dedicated to the dog that was later published as Whym Chow: Flame of Love in $1914 .^{23}$ The poets often called Whym Chow "Dionysus" in writing, signifying their wild devotion to

\footnotetext{
23 Thain calls the volume "a luxurious Mass for the dog" (188).
} 
him, but his death, viewed as a loving sacrifice, is what drove the women to the Roman Church. Thain explains, "there is no doubt that the death of Whym Chow acquired a much greater significance for the two women than it might initially seem to merit because it came to symbolize a crisis of identity" (187). The dog symbolized their bond of love and support, so his death shook the poets to their core.

While Sappho can be read as a mystical third spirit early in the women's union, Whym Chow presents a similar complementary third figure later in their lives. His presence strengthened their mutual bond, and their shared grief for his passing forever changed their views on devoted, religious love. The dog's funeral provides a snapshot of this time of transition: Donoghue points out that he was buried "under the altar of Dionysus in the garden, with an eclectic service that included one of John Gray's Catholic poems" (122). Translating their aesthetic marriage into Christian terms was difficult for the women and I believe it ultimately failed because the union relied on the alternative spirituality of Bradley and Cooper's paganism and their physical and collaborative erotic relationship. Nonetheless, they remained devoted to each other and began to use Catholic symbols and figures in their writing to replace those of ancient Greece.

\section{Michael, Field, and Mary}

Father John Gray oversaw the Catholic conversion of both women, Cooper first but shortly followed by Bradley, early in 1907 (Vanita 132-133). Gray was associated with Wilde, 
and indeed, many aesthetes and decadents converted to Catholicism late in their lives. ${ }^{24}$ Angela Leighton explains that Michael Field was "taking a well-trodden, literary path from revels to repentance. The Catholic Church, with its erotic rituals and emphasis on chastity, was the natural home of the aesthetes" (222). Chastity was indeed appealing to many who harbored same-sex desires, as it shielded and masked their preference by providing an alternative to heterosexual marriage or coupling. The Virgin Mary, in particular, was a figure of "autonomous creativity, power and gentleness, women's community, sympathetic friendship with men, the joy and pain of love, and, most important, no father and no tying-in of childbirth with heterosexual marriage" (Vanita 7). But Cooper chose to offer to the church a vow of full chastity—not only abstaining from sex with men (which would, of course, have been no change for her), but abstaining from all sex. ${ }^{25}$ This caused a distinct change in her relationship with Bradley and, as others have argued, a turning point in their writing as well. Though some scholars, like Sturgeon and Vanita, argue that Field merely exchanged their Classical symbols for Catholic ones, that "the conversion occasions a shift from Sapphic to Marian imagery, but the content does not alter substantially" (Vanita 133), many others identify the declining quality and unity of their work after the conversion. Leighton, for example, bluntly asserts that Catholicism "was not good for their poetry" (222). I argue that the later volumes of Field's poetry do present a progression

${ }^{24}$ This trend, it must be mentioned, follows in the great footsteps of Pater's Marius. For more, see "The Dialectics of Conversion: Marius and Michael Field" by Kit Andrews.

${ }^{25}$ Many sources cite this vow, which also acts as direct evidence of earlier sexual intimacy between the women, who delicately avoided writing about their physical relationship in their journals. 
from pagan to Catholic imagery, thereby emphasizing the continuing importance of paganism even when both women were Catholics. The pagan influence on their later poems thus continues to mask and legitimize their same-sex desire, and indeed is strengthened by the Catholic church's alternative to normative marriage. But the end of their pagan practice and Cooper's vow of total chastity negatively impacted their aesthetic marriage and thus their collaborative work.

After their conversion, Bradley and Cooper published Wild Honey from Various Thyme, Poems of Adoration, Mystic Trees, and Whym Chow: Flame of Love, along with several dramas. Wild Honey was published in 1908, and so is the most immediate volume following their conversion, but it contains poems from the 1890s and only intersperses more overtly Christian poems with those on nature, love, and paganism. This intermingling is representative of the Michaels's continued use of pagan images and their unashamed ownership of their preconversion works, and is also evident in Whym Chow (1914), which they wrote for continuously after the dog's death. Perhaps more noteworthy are Poems of Adoration (1912) and Mystic Trees (1913), volumes that are explicitly Catholic and unique within the Field's oeuvre. These two volumes, published under the name Michael Field and intended to be held together with a specially-designed leather strap, were nonetheless the least collaborative of all Field's work. Poems of Adoration is almost entirely by Cooper, and Mystic Trees by Bradley. This sudden break from their earlier cooperative, collaborative creation process could be attributed to their Catholic conversion, emotional distress caused by the loss of Cooper's sister Amy (in 1909), Cooper's exhausting fight with cancer (diagnosed in 1911), or some unknown factor-but the poems themselves take on distinctly Catholic subjects that move away from the dedicated love between the women and look outward with devotion to their new faith. This digression from 
their life-long unity had been foreshadowed earlier: just after Bradley's baptism, she wrote a poem for Cooper that begins, "Beloved, now I love God first" (qtd. in Donoghue 128).

Stylistically, Poems of Adoration and Mystic Trees are also somewhat different; Cooper's poems are more solemn, portraying a demanding God, while Bradley's are candid and, she thought, overly familiar with God (Donoghue 135-6). Leighton says of the two volumes, "all the serenity and clarity of the early pagan verse has gone from these over-perfumed and erotic obeisances," and adds, "Faith did not re-energize their poetry, but turned it, paradoxically, towards the very flaccid and flowery decadence which they had largely avoided before" (223). The difference in content style, time of publication, and appearance in two volumes separated essentially by author is radically uncharacteristic of Michael Field, whose earlier works were written such that it was virtually impossible to distinguish their origin. To go beyond merely writing separate poems and to bind them separately is nothing less than shocking coming from the women who once claimed their writing was a "perfect mosaic" (qtd. in Sturgeon 47). Considered in tandem with their conversion to Catholicism and Cooper's vow of chastity, these two volumes are evidence of the women's weakened aesthetic marriage. In the absence of the collaborative or physical erotics, Bradley and Cooper had no sexual way to cement the bond of their poets-and-lovers formulation, and thus the "poets" aspect began to crumble as the "lovers" aspect was reduced to chaste affection.

The last factor in an aesthetic marriage, though, Bradley and Cooper tried to revive: their pagan spirituality, which gave them such vivacity as living maenads and productive symbols and images for their poetry, partially transformed after their conversion. The rites and rituals of 
Catholicism echoed the extravagance of Dionysian celebrations, ${ }^{26}$ and Bradley and Cooper relied heavily on their new faith for proscriptive life instruction and habit, attending church and confession regularly, to buttress their identities against the drastic changes happening in their sex and writing. Frederick S. Roden points out that Bradley and Cooper dedicated the same serious attention to their Catholic lifestyle as their earlier pagan one: they wrote about their conversion, sincere faith, and the sacraments in their journal (155). But there were still pagan hints that surfaced occasionally, such as when Cooper refused aggressive cancer treatments in favor of "a decoction of violet leaves in Lourdes water-a suitable mixture of the floral and the mystical" (Donoghue 133). Field's work went through a "transformation-Transubstantiation, if you will—of their earlier 'pagan' Sapphism" into Catholic poems that "incorporate" rather than oppose the earlier work (Roden 157, 156). To enact such a transition, Bradley and Cooper use similar images and symbols but shift their meanings, thereby attempting to continue to shield and validate their relationship in new ways.

In writing, their pagan pasts emerge in Poems of Adoration and Mystic Trees subtly but clearly, illustrating the continuing struggle to represent their same-sex love and unity using spiritual experiences. Bacchic dance is echoed in several places in the Catholic volumes, most directly in Cooper's Salome poem, “A Dance of Death," but also in her "After Annointing," which opens with a very aesthetic or pagan celebration of the sensual: "Joy of the senses, joy of

${ }^{26}$ Many scholars discuss the important similarities between Classical paganism and Catholicism. See, for example, Camille Cauti, "Michael Field's Pagan Catholicism" in Michael Field and Their World, Vanita's Sappho and the Virgin Mary, or, for a more general discussion, Joseph Cambell's The Power of Myth. 
all / And each of them, as fall / The Holy Oils! ... O senses, ye would dance" (MF the Poet 171). But far beyond dance, the language of flowers is particularly noticeable as a consistent motif in the poems of Long Ago and the Catholic volumes. Specifically, roses, lilies, violets, myrtle, and poplar trees are all found throughout Field's poems. Cooper's "Transit" opens with the description of the sights and smells of a passing censer, naming a veritable bouquet of botanicals:

Cloud that streams its breath of unseen flowers, Cloud with spice of bay, Of roses, lily-breathing, and the powers Of small violets, or, aloft, black poplars as they quiver! (MF the Poet 173)

Moreover, the poem equates the incense with Mary in line 9, saying "Mary hath passed by," firmly associating the flowery language with Sappho and her maids of Long Ago, who also are compared to or admire various flowers (MF the Poet 173). ${ }^{27}$ Both volumes often center on the wounds of Christ, which echo Sappho's laments of her penetration and resulting lost virginityan injury from which she cannot recover.

Cooper and Bradley also include apian poems in their Catholic writing, another echo of pagan fertility imagery that ties together yonic flowers and the eroticized wounds of Christ. Cooper's "Imple Superna Gratia" opens with a hyper-erotic description of a bee entering a flower: "We may enter far into a rose, / Parting it, but the bee deeper still", and continues by comparing God's wounds to "sanguine roses" that the bee "attain[s]" and is "feeding" on (ln. 10, 8, 9 MF the Poet 171). Bradley's "Before Requiem" is an ode to bees for furnishing the materials for making the phallic "golden rods" of church candles, and even goes so far as to compare the insects to Angels. Bees, then, make the transition from pagan symbols of fertility to Catholic symbols of holiness. The related language of flowers progresses from pagan uses in

${ }^{27}$ For an extended investigation of the similarities between Sappho and Mary, see Vanita. 
revel-worship to the décor in a church, from Sappho's fair maids and lost virginity to the holiness of incense. The wounds of Christ, common as an erotically-charged image for aesthete converts, became the object of desire in lieu of the same-sex desires in Long Ago. The biblical dance of Salome replaces the Bacchic dance of Maenads in spring. And, as Vanita describes at length, Sappho and her maids become the Virgin Mary and her "company of women," the female saints (30). ${ }^{28}$ Dancing, flowers, Christ's wounds, and even bees were, admittedly, not uncommon in poetry at the time, but their obvious appearance as central motifs in Field's Hellenic poetry and Catholic poetry is evidence for the women's continuing preoccupation with paganism even after their conversion.

Aesthetic marriage is founded on artistic cooperation, alternative sexuality, and spirituality. For the Michaels, it seems that all three began to disintegrate at once: their Catholic conversion, vow of chastity, and shifts in writing practices all contributed to shaking the core of Michael Field's unified identity as pagans, lovers, and poets. But the love between the women never faltered, and they did continue to write under their compound pen-name. Though the symbols they used changed, they also continued to incorporate a spiritual aspect in their lives and art, so although their aesthetic marriage as I define it was disturbed, the women's art, love, and religion remained the foundation of their lives until cancer claimed them both.

28 "Purissimae Virgini Sacellum” in Poems of Adoration frames Bradley and Cooper as devotees of Diana and then "Blest Mary," creating an even more direct link between pagan and Catholic worship via Virgin Goddess figures (qtd. in Vanita 134). 


\section{Conclusion: "The Little Earthly Trinity"29}

The shift from Hellenism to aesthetic Catholicism was a fairly natural one for Bradley and Cooper, as their focus on ritual, art, and the sensual remained at the heart of their relationship and lives despite the changes the conversion brought with it. But these main themes of sex, spirituality, and creativity are found more clearly in their earlier work Long Ago, where the Michaels use the well-established code of Hellenism for their homoerotic desires. To legitimize and express their dedicated same-sex relationship, Bradley and Cooper rely on the recognized voice and constellations of meanings surrounding Sappho. In harmony with the Hellenistic movement coming out of Oxford, Sappho's voice allowed the aunt and niece to recreate or reproduce aspects of the ancient generations in the modern world and replace Christian ideologies, unfriendly to same-sex desire, with pagan beliefs. Sappho also allowed the women to explore alternative genders and sexualities, layering their own gendered identities and their masculine pen-name on an existing tradition of authors using Sappho's speaking voice. Since Long Ago takes Sappho's fragments and extends them into full lyrics, Sappho is also a collaborator with Michael Field—linking all three women in the erotics of collaboration. The first poem in the volume perhaps best illustrates their inseparable unity, the absolute harmony of parts in theme and purpose:

They plaited garlands in their time;

They knew the joy of youth's sweet prime,

Quick breath and rapture:

Theirs was the violet-weaving bliss,

And theirs the white, wreathed brow to kiss,

${ }^{29}$ Qtd. from the Diaries of Michael Field (held by the British Library) in Thain, 187. In this passage, Cooper describes praying for "the little Earthly Trinity" of herself, Bradley, and Whym Chow, to "the ineffable Divine Trinity." 
Kiss, and recapture.

They plaited garlands, even these;

They learnt Love's golden mysteries

Of young Apollo;

The lyre unloosed their souls; they lay

Under the trembling leaves at play,

Bright dreams to follow.

They plaited garlands - heavenly twine!

They crowned the cup, they drank the wine

Of youth's deep pleasure.

Now, lingering for the lyreless god-

Oh yet, once in their time, they trod

A choric measure.

A plait, or braid, is a minimum of three strands (two strands being only a twist or knot) -

Bradley, Cooper, and Sappho individually become a single garland. They know sexual "bliss" with each other, sharing same-sex "kisses" and "rapture." Their erotic desires are supported by artistic creation, an impulse uniting them in aesthetic marriage by the "lyre" of Apollo, dreaming with open souls. And their sexual connections and artistic collaborations are all celebrations of life and love: pagan expressions of unity, wine-drinking and dancing a "choric measure."”30

The plait poem, an exploration of the trinity motif taken up later in the oft-cited "Cowslip Gathering" (Underneath the Bough), indicates the importance of a third figure for the unified Michael Field: first, they relied on Sappho as their predecessor and erotic collaborator, and then in "Cowslip Gathering," "Nature" finds the "twin maiden spirits" and they discover that "In all true marriage perfect trinity" is required (ln. 5, 3, 4). "Nature," the feminized, pagan spirit,

${ }^{30}$ Though in its context it may lament lost virginity, this poem also follows the progression of Bradley and Cooper's religious conversion, as it portrays pagan worship in the past tense and concludes with the "lyreless god." 
unites the women; in the final line of the poem, they are "in one [their] very being blent" (MF the Poet 124-5). Vanita specifies, "It is significant that the wedding is accomplished by Nature functioning as presiding goddess and the 'true trinity' is thus all-female" (120). Michael Field continued to create such trinities throughout their lives - including with Whym Chow, who was first Bacchus and then Christ. In "V. Trinity" from Whym Chow, Flame of Love, the dog is made into the Holy Spirit. The women are united with the dog ("we loved in trinity"), and Whym Chow is the "symbol of [their] perfect union" (ln. 4, 17 MF the Poet 185). Ultimately, Sappho, Nature, or Whym Chow was replaced by the Virgin Mary or God as the third, uniting spirit of their relationship, a symbolic replacement that operated throughout their works and lives.

Trinities of various kinds thus came to symbolize the third element in the women's relationship, which they used to shape, mask, and legitimize their alternative same-sex desires and spiritual impulses. Through writing, Bradley and Cooper explored various aspects of gendered erotic attraction, paganism, Catholicism, and art itself; indeed, for the Michaels, desire is a multifaceted "force which powers art," and their collaborative writing is a central part of love and spirituality (Thain 62). The inherent connections between the three aspects-same-sex desires, spirituality, and cooperative creation - tie the women together in an aesthetic marriage that meant they were indeed "closer married" than normative couples. 


\section{CHAPTER 5: IDENTITY IN PENNY DREADFUL: "WiTHOUT LiMITS"1}

The Victorian genre of the "Penny Dreadful" consists of cheap, mass-produced pamphlets catering to a wide reading public that, as the name implies, cost only a penny. The other part of the name—-Dreadful—conveys the sensational content of the little booklets, which often aimed for shock value or suspense, including murder, monsters, and mayhem. One of the most famous characters introduced by penny dreadfuls is Sweeny Todd, for example, and other Gothic stories or characters, like vampires, were re-written or imitated. Showtime's Penny Dreadful (2014-2016) continues this tradition of imitation, extension, re-writing, and recovery of earlier gothic tropes and characters made available to the masses for wide consumption. ${ }^{2}$ The show explores the world of 1890s London as populated by some of literature and film's favorite gothic and supernatural characters, such as Dr. Frankenstein and his monster, Dorian Gray, and the Wolf Man. Season 1 uses a vampire as its villain, and in Season 3 the antagonist is Dracula himself. Season 2 explores the dark world of witchcraft influenced by the Victorian fascination with table-rapping, seances, and possession. The Victorian era is well-known as a time of rapidly expanding literacy and a growing reading public, creating a market for such cheap and popularly appealing works, and the decades since the invention of television have yielded a similar, popular influence of the public's consumption of stories and information. The show,

\footnotetext{
${ }^{1}$ S1 E6, a phrase used by both Vanessa Ives and Dorian Gray to describe themselves.

${ }^{2}$ The focus on sensational sex and violence coupled with its supernatural elements may make the show more like a "Penny Blood," a somewhat more specific penny-publication genre, but its title complicates the (mis)classification by projecting a modern (mis)understanding of the publications' differences.
} 
then, imitates its titular genre in a new medium by its wide access and sensational appeal, while also maintaining the spirit of pastiche or re-imagining often used by the original little pamphlets.

The translation of the penny dreadful into the sensational television show also imitates a larger trend which looks to the more-or-less historically accurate past as a way of entertaining or illuminating the present. Specifically English historical fiction on television, like The Tudors (BBC/Showtime 2007-2010), Reign (CW, 2013-2017), Downton Abbey (ITV/PBS, 2010-2015), and The Crown (Netflix, 2016-present) are wildly popular. Fantasy-influenced historical fiction, or perhaps historically-influenced fantasy, is also especially appealing at the moment, as evidenced by HBO's goliath Game of Thrones (2011-present). The contemporary interest in historical fiction is also evident in other literary media, and scholars have been investigating our current fascination with the Victorians especially, as Neo-Victorian, Pseudo-Victorian, Victoriana, Gothic, and Steam Punk genres demonstrate, for example in the literary works of A. S. Byatt and Sarah Waters. This trend of interest makes my own investigation of Penny Dreadful worthwhile, because it brings the Victorian world of the dissertation project into conversation with modern storytelling. Part of the fascination is that historical fiction operates in the time it is set, i.e. Penny Dreadful's 1890 s, but is also necessarily part of the time it is written and published or produced, i.e. the twenty-first century. Thus, scholars debate the uses of the historical period, its appeal, and its relationship to the present.

Working from Linda Hutcheon's seminal work on "historiographical metafiction," Kate Mitchell claims that part of the modern interest in the Victorians is based in nostalgia, which helps place the individual in history. Thus, Neo-Victorian literature is not so much a factual reimagining as it is a subjective projecting backwards onto what we think history is. Mitchell says that in this way, we can understand the past through modern points of view, necessarily 
considering the differences between that time and ours; she says that "the Victorian period has been used throughout the twentieth century as an 'other' against which modernity might establish its identity" (8). While this may have been true for Modernists (Mitchell mentions Pound particularly), other scholars contend that Neo-Victorian fiction can operate in the opposite way: by considering commonalities between their world and ours, we can use the Victorian mode to explore our modern milieu. For example, Patrick Hutton contends that today's historians speak less of invoking the past and more of using it. To slightly modify Frederick M. Holmes's formulation, I agree with the scholars who conclude that Victoriana or Neo-Victorian writing "provides us with a provisional structure with which we can make sense of the present."3 More broadly, I agree with Louisa Hadley’s “dual approach,” discussed in more detail below, which acknowledges difference while finding value in similarity.

In Penny Dreadful, many of these complementary ways of looking at historical fiction and Neo-Victorian literature surface. For example, Billie Piper's character, initially known as Brona Croft, is a victim of all-too-familiar sexual violence, but is distanced from modern experiences by living in poverty as a sex worker after escaping from her abusive fiancée. While Brona is not entirely unfamiliar to audiences as a brave but down-trodden single woman looking for work, her life as a "fallen woman" is framed as irredeemable and doomed, not least because she also has tuberculosis. These aspects of her narrative- and, of course, her eventual resurrection by Frankenstein — distance her from modern viewers. After rebirth, the newlydubbed Lily is an exaggerated version of the feminist we glimpse in Brona. Lily uses her

\footnotetext{
${ }^{3}$ Holmes actually asserts that "the [historical] novel emphasizes the efficacy of the imagination in providing us with provisional structures with which to make sense of the past” (331).
} 
sexuality not just to feed herself, but also to target men. While a modern audience can understand the gendered unfairness and double-standards Lily draws attention to, murdering predators can only be a fantasy for women of the twenty-first century. Brona/Lily establishes both parallels and differences between Victorian gender norms and our own, simultaneously drawing our attention to the ways things have changed and the ways they have stayed the same. By removing such on-the-nose gender issues from viewers by more than a century, the show uses its historical fiction framework to show viewers causes, effects, and potentialities that would, perhaps, be too direct or improbable in contemporary realism.

Thus, I argue that Penny Dreadful uses the Victorian setting, various tropes of the gothic mode, and its characters to explore modern anxieties, specifically about sex and personal spirituality. The show's modern production makes it an important addition to my larger project because it brings the Victorians more intentionally into conversation with modern concerns of identity, sexuality, and spiritualism, as I discuss in the terms of Neo-Victorian scholarship. By displacing these modern concerns onto historical fantasy, the show creates distance between its audience and their own established ideologies or beliefs, allowing them room to consider alternatives. These alternatives to current sexual and religious norms are Victorian in the sense that they are stereotypes of and projections onto that era, but also in a more historical sense - the late Victorian sexual scene especially was in flux as definitions and identity markers were just beginning to solidify and spread. Penny Dreadful uses this period to illustrate the potential power of returning to undefined sexuality or, to paraphrase Foucault in reverse, Penny Dreadful demonstrates the potential power of returning to a time when there was no queer "species," only queer acts. 
Despite this novel approach to identity, the use of well-known characters and gothic tropes creates a sense of confident familiarity for the audience, allowing for a serious thematic investigation of the overlapping aspects of sex and the supernatural. In other words, using the specifically Neo-Victorian mode allows Penny Dreadful to "remythologize Victorian events and icons to make them newly available for politically self-conscious subjectivities" (Kucich and Sadoff xxvi). ${ }^{4}$ Because the audience is likely to be at least vaguely familiar with Frankenstein and his monster, Dorian Gray, and Dracula, they are not in suspense about those characters' backstories or development. Instead, the characters create interest by not being tied to their sexual identities in the ways that many modern characters are-other TV shows tend to parade out their representative queer characters and shape entire personalities around being LGBTQ+. But Penny Dreadful treats sexuality as a feature or side-effect of the supernatural instead: the primary identifying category of most characters isn't whether they are straight or gay, it's whether they' re human or what Kelly Hurley calls "abhuman," which I discuss below. I'd like now to turn more directly to Vanessa Ives and Dorian Gray and their experiences with sex and the supernatural to examine how the relationship between erotic acts and spirituality can provide new modes of relation for the audience to consider.

\footnotetext{
${ }^{4}$ My inclusion of the show as part of this larger project is thus valuable as a way of making the Victorian works of the preceding chapters "available" or deployable for active modern engagement as well.
} 


\section{Vanessa and Genre: "Like an echo already passed"}

Despite the show's large and varied cast of familiar characters, the protagonist is the invented Vanessa Ives, played by Eva Green. The show follows her from Season 1's quest for rescue and vengeance, through Season 2's struggle against a coven of witches tempting her to evil, into Season 3's surprising surrender to her dark side. I focus on Season 1, as it establishes character histories and specific paranormal abilities, and, a bit later, Season 3, because the conclusion of the show demonstrates Vanessa's radical end. Her history of betrayal, insanity, torture, and education is told largely through flashbacks, and a love story between Vanessa and Ethan Chandler (played by Josh Hartnett) slowly unfolds. She may not have roots in a period literary work, but she is undoubtedly (Neo-)Victorian in that she is molded from very familiar clay.

Though she is a new character made for the show, Vanessa is also a traditional gothic heroine as described by Eve Kosofsky Sedgwick: she is the hysterical woman who has an “immobilizing and costly struggle, $[\ldots]$ to express graphically through her bodily hieroglyphic what cannot come into existence as narrative" (Coherence vi). Vanessa's struggle against the monster becoming the self (to paraphrase Barbara Johnson ${ }^{6}$ ) is written on the body. For example, in Episode 7 of Season 1, Vanessa's darkness manifests as a literal hieroglyph of blood vessels on her chest. Moreover, her narrative is "unspeakable" when she is possessed by her evil self because she is often incapable of speech, or only capable of speaking the verbis diablo - the

\footnotetext{
${ }^{5}$ Vanessa describes the imprecise nature of reading her tarot cards to find Mina in S1 E6. ${ }^{6}$ Johnson’s 1982 essay “My Monster/My Self” appears in A Life with Mary Shelley, Stanford UP, 2014, pp. 15-26.
} 
devil's tongue. These bodily changes and Vanessa's overarching story of fighting "the monster within"7 also match her with Hurley's definition of the abhuman: she is "a not-quite-human subject, characterized by its morphic variability, continually in danger of becoming not-itself, becoming other" (3-4). ${ }^{8}$ These recognizable gothic characteristics make Vanessa readily identifiable as a Gothic heroine despite her invention for the show. Using gothic conventions and tropes like the abhuman, we can see Vanessa is a Neo-Victorian creation, an imitation or reimagining of the Victorian original that serves to distance modern concerns for the audience while keeping them accessible. Moreover, her position as abhuman inhibits audience categorization of her as chaste or sexual, good or evil; it sidesteps sexual and moral identity by placing emphasis on overlap, conflation, and confusion manifested in her magic. The audience is thereby encouraged to consider life in the gray areas, and the potential of denying dominant identity markers.

The liminal position of Penny Dreadful's genre as Neo-Victorian, between strictly historical or modern, is reinforced by Vanessa's own position as in-between the opposing existential and moral categories of self/other, good/evil, and more. Similarly, Julia Kristeva's concept of the abject, which emphasizing the contradictory impulses of attraction and repulsion of horror, is clearly implicated by Vanessa's storyline. The show is full of gore, but we cannot look away. Vanessa's position on the cusp of familiar and foreign echoes Kristeva's definition

\footnotetext{
${ }^{7}$ Amunet (Vanessa's supposed alter-ego) is “The Hidden One," Egyptologist Ferdinand Lyle explains to Sir Malcolm Murray in S1 E2, "because despite her outward divinity, she had a monster within her, not unlike your Miss Ives." More on the Amunet storyline below.

${ }^{8}$ For example, the Beetle woman I discuss in Chapter III is abhuman.
} 
of the abject, which she says is caused by "what disturbs identity, system, order. What does not respect borders, positions, rules. The in-between, the ambiguous, the composite" (4). Vanessa, therefore, embodies abjection as she is both-and-neither herself or other, good or evil, historical or modern, etc.

In S1 E6, Vanessa and Dorian go on an "adventure" to have their photographs taken, then have dinner together and return to Dorian's townhouse. Several details from these scenes invoke abjection, and Dorian prompts Vanessa to talk about her spirituality and identity before they return to his home and have sex. Vanessa and Dorian discuss their different (yet similar) paranormal positions in terms of the abject: Vanessa's continuing struggle against her darker self leaves her in a position, as Kristeva puts it, "on the edge of nonexistence and hallucination, of a reality that, if I acknowledge it, annihilates me. There, abject and abjection are my safeguards" (Kristeva 2). Instead of "annihilation," in Kristeva's formulation, Vanessa chooses the "edge" of her supernatural abilities, attempting to use them without letting them overpower her, continually fighting down the demons, but refusing to finally choose either side of her nature. The conversation between Vanessa and Dorian at dinner is worth quoting nearly in full:

Vanessa: "I have a complicated history with the Almighty. I think, Mr. Gray, there are...tremors around us. Like the vibrations of a note of music. Hidden music. Some might be more attuned to them than others." [Vanessa's theme plays] "What do those people do, those who have been chosen?"

Dorian: "They endure uniqueness." [she laughs] V: "To be alien. To be disenfranchised form those around you. Is that not a dreadful curse?" D: "To be different, to be powerful, is that not a divine gift?"

V: "To be alone."

D: "To be seeking."

V: "What?"

D: "Another."

V: "Like you."

D: "Who shares your rarity."

V: "Then you are no longer unique."

D: "Nor are you alone." 
At this point in the show, Dorian's immortality has not yet been established, so the conversation shows Vanessa's abject position in particular. Their conversation is held entirely in the hypothetical, as they are concealing their supernatural elements from each other, and so the end of the exchange, while hopeful (and intentionally seductive), is inconclusive. Vanessa's refusal to choose a side means she is precisely within the realm of the abject and abhuman — she rides this "edge" to refuse choice, because to choose one part of herself over another would be to give up her "uniqueness." This puts Vanessa in a queer position where socially-imposed identity is virtually meaningless; she does not conform to categories, especially spiritual categories, and her abjection thereby refocuses audience attention on her agency and choices.

But it is not only Vanessa who is abhuman and abject; the very genre of Neo-Victorian or historical fantasy is in-between, neither purely Victorian nor modern, authentic nor nostalgic, realistic nor fantastical. In this way, the show is also abject, on the "edge." Its genre identity “does not respect borders” or historical truth (Kristeva 4), and Penny Dreadful's layered historicity adds precisely the complexity that I assert makes its genre influential. The show contains characters from different fictional texts spanning more than a century, placed together in the same London. Moreover, the London of the show itself is composite: it cannot be all of the Londons of the source novels, as they span so many years, but neither can it be the London of 1891, which would be impossible to truly, accurately reproduce. It is certainly not the London of today, but it does exist today as a filming set, as models, and as CGI. These complex positions of reality, time, and space in the show are echoed by its occasional doubling of visuals. In the same episode just discussed, Vanessa confesses she has never had her photograph taken and cites "native tribes who believe you give away something of your soul when you're photographed," directly indicating traditional material duality. But the camera work of the show makes it abject, 
foreign, by focusing on Vanessa's reflection on the front face of the camera lens - and doubly so, as we are watching the scene through our TVs after it has been filmed and edited. The visuals of the scene thus emphasize the doubling of the abject and Vanessa herself while drawing attention to the artificial nature of the show.

Meta-awareness of the fourth wall and its implications when discussing photography in the scene provide one example of the show's abjection, and Penny Dreadful's Neo-Victorian genre itself is also in-between, liminal, or on the "edge" of the camera lens. Like a photograph, it attempts to reproduce (historical) reality in a new form - to translate from life, to create something material from a moment, to generate something more permanent or more shareable than memory. Neo-Victorian works have various aims, but many scholars of the genre make similar connections to photography, a great Victorian invention of permanence. ${ }^{9}$ Hadley calls this translation from life or history to modern media a kind of ventriloquism, which "involves both speaking like and speaking as a Victorian" (159). I'd argue that such ventriloquism across time is more like a séance, as the medium of today channels the past, its modes, its characters, and its places. The show, then, is the clairvoyant, bringing Victorian fiction from the past to the present moment. Neo-Victorian pastiche like Penny Dreadful thus resurrects its characters from the dead to put them in a new setting - making them simultaneously old and new, historical and modern.

\footnotetext{
${ }^{9}$ Dorian explicitly disagrees, saying, "Photographs are so ironically...impermanent. They capture one moment in time to perfection. A painting can capture eternity" (S1 E6). His point is the emotion and movement a painting can "capture," but also, of course, about his own immortality. We must wonder what he would make of moving pictures.
} 
Beyond this language of mediums, clairvoyants, ventriloquists, and resurrection, NeoVictorian works have numerous other metaphorical connections to the abject, monstrous themes under investigation here. The composite aspect of Penny Dreadful in particular echoes Frankenstein's monster, as 'dead' characters are spliced together and brought back to life via the 'shock' of television. John Kucich and Dianne F. Sadoff say that the genre is "vampirizations of the Victorian cultural past; uncanny hauntings of our moment by its historical selfrepresentations" (xvi). This ghostly language is echoed by other scholars: Hilary M. Schor says, "the Victorian past has come to uncanny life in contemporary fiction," and that such works of fiction "invoke a series of spectral Victorian predecessors" $(234,235)$. Schor also calls the genre "reincarnation" and "ghostwriting that is speaking with the dead, not so much as writers but as moldering bodies, decaying forms" $(235,237)$. Neo-Victorian fiction, then, works as a supernatural conduit or "ghostly afterlife" for Victorian works, characters, and themes, but leaves the elements queerly caught between their origins and their modern incarnations (Thomas 289). These boundary-defying genre elements of such works as Penny Dreadful serve to draw the audience's attention to the complexity of lived experience and the individual's place in history with a specifically supernatural mode.

Vanessa asks Ethan, "Do you believe there is a demi-monde, Mr. Chandler? A half-world between what we know and what we fear. A place in the shadows, rarely seen, but deeply felt. Do you believe that?" "Yes," he firmly replies (S1 E1). Penny Dreadful uses many layersVictorian, modern, existing fiction, new invention, realism, fantasy, and more - to convey the multiplicity of experience and the potential for living in a "half-world" between categories. Moreover, as this selection from the very first episode indicates, the show knowingly interacts with such liminality and, indeed, draws attention to the "places in the shadows." For an 
observant audience, lines like these prompt us to question our understandings of history and how our own (modern) world creates composite narratives. It highlights the fact that reality itself is multiplicitous, and that the places and people we know are composites of their own histories. So the genre, camera work, even location encourage viewers to be aware of categories and how to reject them. This mode is what allows the audience to disassociate or disengage from the modern world while simultaneously illuminating modern issues of identity.

\section{Miss Ives, "The Most Mysterious Thing in London" 10}

Vanessa's unique position as the "mother of all evil" (a title which appears first in S1 E2 and is used repeatedly) makes her always-already the monster within this haunted genre. But one interesting thing about Neo-Victorian stories is their approach to historicity and the remaking of the contextual "normal" that the monster operates in opposition to. For example, Vanessa is an unmarried, sexually active young woman, but she is still able to circulate in the highest social circles without the show making much of an issue of her reputation. As cited above, some critics note that modern interest in historical fiction frames the Victorians as distant and different from us and investigates the changes between that context and ours, often falling prey to stereotyping or nostalgia or, perhaps in the case of Vanessa, anachronism. Other critics, though, argue that the Victorians are so fascinating because we have come to recognize how much we have in common. Taking both difference and similarity together, Hadley argues, "NeoVictorian fictions, then, are not merely part of the contemporary fascination with the Victorian past; they are aware of the purposes the Victorians are made to serve and in returning to the

\footnotetext{
${ }^{10}$ S1 E4; Dorian Gray toasts Vanessa Ives with Ethan Chandler.
} 
Victorians self-consciously comment on the political and cultural uses of the Victorians in the present" (14). In this way, Vanessa's social standing, historically inaccurate as it is, connects the 1890s to modern cultural norms. She does not have many friends and is often isolated, but isn't actively prevented from travelling in public social spaces. Her supernatural monstrosity, intrinsically related to her sexuality, serves to set her apart, yes - but she is portrayed as troubled, introverted, self-driven to solitude, not shunned or cast out of company.

Vanessa's choices demonstrate that Penny Dreadful is indeed engaging with the Victorian (fictional) historical context deliberately, and that the show does so to "selfconsciously comment" on the present, where, ideally, women can choose the circles in which they travel. Moreover, when Vanessa does have social troubles, they focus on her uncanny psychic ability, not her sexuality. In S1 E2, the Egyptologist Ferdinand Lyle invites Sir Malcolm Murray and Vanessa to a "wee fête" at his home, where he entertains his guests with a séance lead by Madame Kali (later established as the real witch Evelyn Poole, the villain of Season 2). ${ }^{11}$ But when Madame Kali invites spirits to join them at the table, she discovers that there is

${ }^{11}$ One of the great popular Victorian pastimes of the superstitious and the skeptical alike, séances allowed participants to have "a fascinating, disturbing, and sometimes even lifechanging experience. Many saw in them the fulfillment of the mind's greatest potential," as the impressive influencing power of the mesmerist and sharpened senses of the mesmerized were often the results (Winter 3). Moreover, "The question of whether the effects were natural or supernatural made experiments a testing ground of faith and doctrine" (Winter 4). Though séances had fallen out of style for posh parties like Lyle's by the 1890s, they were certainly popular in such settings through the middle of the nineteenth century. See Winter for more. 
"another" at the table — presumably another medium or someone with paranormal abilities. She identifies Vanessa as "Amunet," whose "lover" and "master" is the devil, and Vanessa becomes dramatically possessed by Sir Malcolm's son, Peter, and then daughter, Mina (S1 E2). Vanessa chose to attend the party and, led by Dorian, also chooses to join the séance table, despite knowing the dangers of engaging with her supernatural powers. These choices lead to her shocking possession, but later it is clear that Lyle, the host, does not shun her. Indeed, he becomes quite close friends with her through the ensuing seasons.

Throughout Lyle's fête, several details serve to emphasize Vanessa's supernatural ability rather than her sexuality. Although the show shifts audience focus to the mystical events portrayed, desire and sexuality do play a distinct role in the scene. Especially within the Victorian context, Vanessa's possession is wildly sexual— to begin with, she chose to not wear gloves to the party, which Dorian comments on and Madame Kali draws attention to when she requires the other ladies to take theirs off for the séance. This links her bare arms and hands to raw sexuality, vulnerability, and availability while also making bare hands and touching skin an important feature for supernatural conductivity; ${ }^{12}$ Alison Winter says that for channeling spirits, such close contact was encouraged to "allow for the flow of mesmeric fluid" between those involved (140). While possessed, she clutches the hands of the people on either side of her to her breasts and talks about Malcolm's graphic sexual transgressions, using words like "fucking" and

\footnotetext{
${ }^{12}$ I evaluate a similar moment of gloveless contact in Chapter I, where Teleny and Des Grieux shake hands. Their skin-to-skin touch causes a "magnetic" connection and Des Grieux says, "I actually felt I was being taken possession of" (11).
} 
"cunt." After she storms out, her erotic desire—perhaps caused by her possession—drives her to have sex with a strange man in the street.

Despite all of these sexual details, the episode hinges instead on her supernatural ability and the shock of her possession. Even when she 'becomes' Malcolm's son, the gender transgression is second to the sensational aspect of her raw ability to channel the dead. ${ }^{13}$ Throughout the séance, others at the table and the crowd of partygoers in the room are in shock, gasping and screaming in horror as Vanessa reveals Peter's grim death. She crawls on the table, growls, moans, and ends the spectacle by doing a gravity-defying back-bend over the table while speaking the verbis diablo to a chorus of women's screams. Later, though, Lyle comments on her bad language, and then he says of Vanessa, "if one is to engage with the primordial forces of darkness, one must expect a bit of... social awkwardness," demonstrating that what we are meant to take away from the scene is not Vanessa's sexual transgressions, but her spiritual powers (S1 E2). Lyle clearly states that any "social awkwardness" would be due to Vanessa's unexpectedly powerful ability to channel spirits, not the gloveless hands or later sex (which only Dorian witnesses). Penny Dreadful thus conveys to modern audiences the potential for people to move

${ }^{13}$ The spiritual subject for mesmeric states was generally a woman, as women were believed to be simpler, in a mental state closer to nature, weaker, and thereby easier to influence or control (Winter 1-2). But such possession of a woman by a man was often controversial, as she was then free to act on her desires or transgress other gender norms under the (potentially faked) guise of losing control of her body. Winter explains, "mesmerism threatened more than a figurative seduction," since it "invited [subjects] to pretend to succumb" to literal seduction (101). See her section, "Weak Women and Weaker Men" for more (100-102). 
past social identity constructs based primarily in sexuality. Instead of merely a sexual deviant or 'fallen woman,' the audience is asked to consider Vanessa as a powerful player in the larger cosmos of good and evil forces.

Lyle's party also serves as an important plot point in establishing Vanessa's connection to Amunet as mentioned above, and reinforces her abject liminal position—Madame Kali calls Vanessa Amunet at the séance, but it is unclear what this means at the time. After the party, Malcolm goes to see Lyle about translating the hieroglyphics found on the vampire killed in episode 1, and they discover that the vampire's corpse tells the story of Amunet joining with her forbidden lover, Amun-Ra. Lyle is terrified by this discovery, and explains to Malcolm: Amunet and Amun-Ra "never appear in the same incantation. It is inconceivable in pharaonic religion to conjoin them. Their narratives are kept completely separate $[\ldots]$ because, if they ever came together, Amunet would become the mother of evil. All light would end. The world would live in darkness, the Hidden Ones would emerge and rule.” But Amunet and Amun-Ra are shown conjoined in the vampire - and Vanessa is, they deduce, a reincarnation or embodiment of Amunet. The story of forbidden (sexual and metaphysical) joining of Amunet and Amun-Ra echoes the abject in its push and pull: it appeals - it is desirable, but it also repulses—it is dangerous. Vanessa's conflict, then, is one of resisting sexual longing and mystical powers while still feeling, even reveling in, their attraction.

The séance is made doubly abject by its camera work, which estranges viewers from the scene by frequently interposing reflective surfaces to show the action. It balances on the edge of portrayal by placing an imperfect medium between the viewer and the scene- at several points a convex mirror, at others, the mirrored glass top of the séance table. Near the beginning of her possession, Vanessa leans over the mirrored table and it suddenly shatters, spider web cracks 
spreading across the entire surface. As the viewer watches her reflection break and multiply, then learns of her alter-ego Amunet and her story of forbidden unity, the show demonstrates Vanessa's abjection. Clearly the sexual aspects of Vanessa's spirituality are important, but the show maintains sharper focus on her supernatural ability — to fragment or multiply herself by channeling spirits or by becoming a reincarnated Goddess figure-instead of her obvious erotic expressions and transgressions. Instead of sexual identity, these supernatural abilities make up the focus of the show, driving the plot and most of the character development. These imperfect reflections of Victorian expressions of sexuality and spirituality, their interconnections and their impact on Vanessa's identity, can inform modern audience experiences.

Despite Vanessa's fractured, abject nature, the message she can send is based in the combination of these multiple elements. Jack Halberstam writes in Skin Shows that "the Gothic monster is precisely a disciplinary sign, a warning of what may happen if the body is imprisoned by its desires or if the subject is unable to discipline him- or herself fully and successfully. [...] The monster (from de-monstrare) encourages readers to read themselves and their own bodies and scan themselves for signs of devolution" (72). Halberstam's formulation of the monster combines Vanessa's sexuality and the show's focus on her mystical powers to embody a totality of negative characteristics. In this way, Vanessa is an example of what can go terribly wrong if a young woman gives in to desire and has sex before marriage: she will become a literal devil. We discover in a flashback that just before her best friend, Mina Harker's wedding, Vanessa has sex with Mina's fiancé. The wedding is then, obviously, canceled. Vanessa is punished repeatedly_Mina is heartbroken and later taken by a vampire and ultimately killed, their families feud, Vanessa goes insane, is tortured in an asylum, and has to live with guilt forever. Moreover, she struggles continuously with the demon inside her, which is triggered repeatedly 
by later sex acts. Including her initial transgression, Vanessa is shown having on-screen sex four times in the first season: the first, with the stranger in the street immediately after she is possessed at Lyle's séance, the second, with Mina's fiancé in a flashback, and then shortly thereafter, with the devil, who appears to her as Sir Malcolm, before she becomes possessed and is taken to the asylum. ${ }^{14}$ Finally, in S1 E6, she has wild sex with Dorian, which causes another supernatural episode. Using Halberstam's logic of monsters, the message is clear: women's erotic desires invite or are caused by the devil, and to act on them causes supernatural and psychological disaster.

Vanessa is the perfect gothic example of what not to do, by Halberstam's definition of the "technology of monsters," illustrating the extreme taboo against women's desire in both the Victorian age and ours. Punishing a Victorian woman for having sex doesn't significantly differ from similarly punitive messages found all around us in the twenty-first century. Penny Dreadful uses these elements of the gothic and monstrosity to ask the audience to reconsider our modern notions of sex and the supernatural. The show's Neo-Victorian genre, with "its elements of mixing and matching on a formal level [...shows that] to look at the present is to estrange it as well" (Schor 239). "Looking at the present" through the lens of the Victorian woman punished for sexual transgressions allows the audience to become "estranged" from their own context— to step back from modern society and to recognize the similarity they are usually too close to see in order to critique it. But the message we get from Vanessa-as-monster goes further: she is even more complex than the picture I've painted so far; she is the protagonist. As I mentioned, she is

\footnotetext{
${ }^{14}$ This is shown onscreen from her mother's point of view as Vanessa naked in her bed, having sex with thin air (since her mother cannot see the devil).
} 
not excluded from high society. She uses her demonic powers to help find and attempt to rescue Mina, to fight vampires, and to defeat a coven of powerful witches. She is brave in the face of terrible horror, and saves her comrades from sure death multiple times. She uses her monstrosity as her strength; she dreads her evil side but uses her supernatural abilities for good until she no longer can.

The message we get from the "immobilizing and costly struggle" Sedgwick describes is that Vanessa is both connected to a larger fate, but also in control of her own identity (Coherence vi). Her sex acts or erotic desires seem to trigger the monster within, but when she accepts her supernatural powers she can control them, use them, and be her most authentic self. The connections between her sexuality and spirituality make her powerful, and her destiny as part of the battle between good and evil is the focus of the show. Indeed, when she accepts her fate and herself and partners with Dracula in Season 3, the sex they have does not trigger a psychotic break, but a newfound (though somewhat remorseful) peace with her demonic abilities. Though still paired, it becomes even more obvious in Season 3 that the show de-emphasizes Vanessa's sexuality to highlight the larger ideas of morality and self-determined identity via her spiritual struggle.

\section{Season 3's Queer Failure}

While Season 1 establishes the show's layered genre and Vanessa's supernatural abilities, Seasons 2 and 3 explore the men who desire her and desire to possess her. Season 2 follows a coven of witches led by Evelyn Poole (the same Madame Kali of the séance) as they try to seduce Vanessa to the dark side for their Master, Lucifer. The show reveals through extensive 
flashbacks that years earlier Vanessa had been trained as a "day walker" (good witch) by the cutwife of Ballantree Moor, Joan Clayton. It is Clayton who identifies Vanessa's witch-totem, a scorpion. The scorpion motif is present from the very first episode of the show, as it is part of the opening sequence, but in Season 2 we discover it has power as a touchstone for Vanessa. Throughout Seasons 2 and 3, the small, dangerous creature appears repeatedly, often as a protective mark drawn by Vanessa in her own blood. The scorpion comes to symbolize her power, her monstrosity, and her ferocity, but it is also auto-destructive and indicates the surrender of her humanity. The scorpion is most powerful as protection after Vanessa cuts herself, transferring her lifeblood to the totem, which she draws on a threshold surface: a gate post, a door. It is, then, a sign of the mystical body, of masochism, of transference, liminality, and power at the abject edges of things.

I begin with the symbol of Vanessa's blood scorpion because it provides a transition through Season 2 to Season 3 through the "queer failure" of Vanessa to contain, control, or preserve her bodily integrity precisely at the same time she is resisting the social and moral obligation to contain, control, or limit her supernatural abilities. In The Queer Art of Failure, Halberstam explains that such masochistic acts "dramatize new relations between body, self, and power," which can result in what he calls "queer failure" (235). ${ }^{15}$ Vanessa's use of the scorpion demonstrates her choice to risk using her powers - to risk her self being subsumed by the dark side — while it is also a choice to do herself bodily harm — to risk weakening and, perhaps, death. Being drawn in her blood, this means Vanessa's scorpion, according to Halberstam's theory of

\footnotetext{
${ }^{15}$ In Season 3, Vanessa is also repeatedly shown scratching her hands bloody, a specific tick addressed by her therapist, Dr. Seward and another masochistic act.
} 
queer failure, is "a feminist aesthetic proper to the project of female unbecoming. [...It] represents her attempt to remake herself as something other than a repository for" cultural norms and expectations ( $Q A O F 135)$. By creating a new, in-between space, neither day-walker nor night-walker (good or bad witch), Vanessa boldly inserts herself in the supernatural realm as an individual.

In the final episode of Season 2, Lucifer offers her a "normal" life in exchange for her soul, but Vanessa says, "Why do you think I want that anymore? I know what I am. Do you?" Her frank refusal to choose, even between the full manifestation of her supernatural abilities and a "normal" humanity, demonstrates her determination to forge her own path. Visually, this decision to not give up her soul, her powers, or her agency is symbolized by the image of scorpions again, which pour out of the devil-poppet after she defeats it. A single, pale scorpion crawls onto her hand, and as she watches, it is absorbed into her palm, becoming one with her body. She continuously radically refuses categories, as we see in Seasons 2 and 3 when she embraces and represses her powers, using them for both good and evil. Ultimately, she fulfills the "project of female unbecoming" by choosing death.

Season 3 explores the aftermath of the physical and psychological trauma of Season 2. Lyle escapes to Egypt, Ethan travels home to the American West, and Malcolm finally embarks on his long-planned trip back to Africa. Vanessa, left alone, seeks counseling. She also meets a seductive new man who turns out to be Dracula. Her counselor, Dr. Seward (who is played by Patti LuPone, the same actress who portrays Joan Clayton, her original mentor) hypnotizes her ${ }^{16}$

\footnotetext{
${ }^{16}$ While the therapeutic hypnosis portrayed in the show is certainly a convenient way of introducing a flashback, it also has Victorian historical basis. Beginning as early as the 1840s,
} 
and we get flashbacks that finally reveal the details of the struggle between Lucifer and Dracula for Vanessa. In the flashback, the two competing supernatural suitors plead, bargain, and threaten Vanessa: Lucifer wants her complete spiritual surrender so he can pair with her soul, while Dracula wants her bodily surrender so he can join with her erotically. She defends her independence from them, rejecting, refusing, and banishing both, and we the audience can see the heavy-handed message of the soul/body duality and the temptation of evil and sex embodied in the two men. ${ }^{17}$ The obvious message for viewers is heteronormative in the extreme: women must resist moral wrong and sexual desire, and the stakes are as high as the end of the world itself.

hypnotism was viewed as one of many psychical sciences and was treated as a medical tool and area worthy of serious intellectual inquiry. It was used as an experimental anesthetic and within physiology to attempt to address the unconscious mind (Winter 184-5, 287). Just as portrayed in Dr. Seward's office, "the trance [is induced] by a combination of imagination and attention [and was] produced entirely by the subject's own mind in interaction with an external sensory stimulus," in Vanessa's case, a blank spinning wax gramophone cylinder creates a white noise akin to static (Winter 185). The resulting trance left Vanessa able to "smell, hear, and see things that normal people could not" from her memory (Winter 288). In a nod to the historic popularity of hypnotism, Dr. Seward says, "it's not like the music-hall acts" (S3 E3).

${ }^{17}$ It must be mentioned they are played in the scene by just one man, the asylum orderly who becomes possessed, or Vanessa projects their presence into his imagined form. This undoes some of the splitting of the body/soul duality and indeed presents its opposite: that the material and the metaphysical are one and the same. 
Returning to the real-time storyline of the narrative, however, complicates this message. Dr. Seward encourages Vanessa to find new experiences, or to do something that she thinks will make her happy no matter how “capricious or unlikely," and Vanessa repeatedly seeks out Dr. Alexander Sweet, who works with the "night creatures" at the Natural History Museum and who, of course, is secretly Dracula (S3 E2). The show thus challenges its normative message predicated on the dual seductions of body and mind by allowing its heroine to choose, to explore, and even to follow her desires. She enthusiastically gives in to Sweet's advances and they have sex in the museum surrounded by the very predators who symbolize her dark side, thereby fulfilling the prophesy of her fall and initiating the end of the world. As discussed above, Vanessa's other erotic encounters were always linked to episodes of possessed psychosis, but the transformative erotic encounter with Sweet-Dracula does not cause such an episode. ${ }^{18}$ Rather than sex triggering or being triggered by her supernatural powers, it seems that acquiescing to her destiny causes a deep peace (or at least quiet resignation). This peaceful state returns focus to her spiritual position, rather than lingering on the sex act that caused it. But her tranquility leaves more questions than it answers, each with its messages for the modern audience. Was she being punished for having sex with other men, because Dracula had a claim on her? Is she now, or was she, held in his vampiric thrall, negating any agency? Is her two-and-a-half-season, 23episode resistance overcome merely because Dracula is ridiculously good looking?

The answers, I argue, hinge on the entirety of Vanessa's character as discussed here. She stands as a composite of re-imagined Victorian ideals placed in front of a twenty-first century

${ }^{18}$ Though Vanessa might not be aware, at first, that Sweet is Dracula, she is still choosing to have sex with him despite this history of possessions linked to intercourse. 
audience: she is an abject, abhuman figure always on the cusp of falling to a side; Amunet, sexual agency, and guilt for moral wrongdoing all haunt her continuously. But more importantly, she has refused, thus far, to choose between light and dark. She has both rejected and embraced her powers, resisted and capitulated to erotic desire. Her options have been presented numerous times: in S1 E5, the flashback to her first sexual transgression and subsequent visitation by the devil as Sir Malcolm includes a long conversation with him about her choices. The devil-as-Malcolm says to her, "you've always had a choice. You allowed all this to happen. Hell, you sought it out and fucked it. You could have shut the door at any time. You still can. Right now. Will you?" She rejects him, saying, "Yes." But a few moments later, she gives in to him by saying "yes" again is precisely the same way. Similarly, Dorian can see the conflict within her when they return to his home in the episode discussed at length above (S1 E6):

Dorian: "You have exceptional composure."

Vanessa: "Do I?"

D: "Poise I mean."

V: "Control."

D: "Yes. What if you were to abandon it?"

V: "I couldn't."

D: "Why?"

V: "There are things within us all that can never be unleashed."

D: "And what would happen if they were?"

V: "They would consume us. We would cease to be, and another would exist in our place, without control. Without limits."

Vanessa's choices, then, have been made clear all along: she can choose body or soul, good or evil, control or freedom. The sex she has throughout the show cements or is evidence of her choices, but the choice itself is about identity and spirituality. Since Vanessa knows that sexuality and her possessed episodes are linked, each erotic encounter highlights the decision she makes to experience the supernatural part of herself. Until Season 3, though, she has ridden the 
line between her main options of good (chaste) and evil (intentionally joining with Satan or Dracula), remaining a liminal figure of abjection, always at risk of becoming not-herself by giving in to a ready-made option.

Instead, Vanessa chooses not to choose. She embraces a last act of pleasure by having sex with Sweet-Dracula because he makes her happy. But then she refuses the options of light and dark by deciding to fail, to un-become, to die. Halberstam asks, "what kinds of reward can failure offer us? Perhaps most obviously, failure allows us to escape the punishing norms that discipline behavior and manage human development," like moral and sexual conformity ( $Q A o F$ 3). Vanessa's queer failure allows her to opt out of a system designed for women's subjugation or obedience. She opts out of a system that was only navigable by denying parts of herself. Instead, she chooses to be fully herself, powerful, flawed, desiring, good and evil—she accepts herself as outside norms and embraces destruction because she understands the radical possibility of such self-acceptance, but also its impossibility within hegemonic systems of control. ${ }^{19} \mathrm{Her}$ death creates "a shadow archive of resistance, one that does not speak in the language of action and momentum but instead articulates itself in terms of evacuation, refusal, passivity, unbecoming, unbeing" (Halberstam, $Q A O F$ 129). As Halberstam's theory of queer failure makes

${ }^{19}$ Halberstam cites such impulses in his discussion of Low theory: "Low theory tries to locate all the in-between spaces that save us from being snared by the hooks of hegemony and speared by the seductions of the gift shop. But it also makes its peace with the possibility that alternatives dwell in the murky waters of a counterintuitive, often impossibly dark and negative realm of critique and refusal" ( $Q A o F 2)$. 
clear, this "archive of resistance" is possible — even necessary—in the real world of Penny Dreadful's audience as a social and political mode.

Echoing scholarly debate about Neo-Victorian works, show creator John Logan says, It's important that even though we're set in 1891 and we have corsets and long dusters and it's dark alleys and it's London, that it's very much a modern show. [...] You know, I think we all feel we will have failed if this is seen as a museum piece or as a quaint presentation of another time, because if we're not speaking to what it is to be alive today, there is no reason to do it. (qtd. in Arenstein 1)

Vanessa's queer failure does speak to a modern audience: just as Halberstam's Queer Art of Failure argues, social and political potential lie outside normative options of good and bad, light and dark, chaste and passionate. Despite its setting, historical references, and tropes, "in the end, it's clear that the monsters in question are merely fictional representations of the real-life predators who haunt our everyday reality" (Arenstein 1). These "monsters" are not the werewolves, immortals, witches, and mad scientists who make up the main characters of the show - the real monsters are the pressures, norms, and expectations of hegemony that the show highlights by rethinking identity. Vanessa's "failure" is her choice to opt out of the system, to reject all the options in favor of unbecoming. As Halberstam says, "failure [...] provides the opportunity to use these negative affects to poke holes in the toxic positivity of contemporary life" $(Q A o F 3)$. 
IV. Dorian Gray: "A longing so deep and dark and rare"20

Vanessa's character arc sets up the queer failure at the end of the series to highlight the potential of rejecting the entire hegemonic system of obedience, choice, and reproduction of norms. Moreover, although they are intrinsically connected, her portrayal focuses on her paranormal abilities instead of her erotic encounters to continually shift audience focus from sexual identity to spiritual potential in such radical resistance. The interplay between Vanessa and Dorian Gray, discussed at various points above, is illuminating as their conversations work to develop both characters, and Dorian serves as an excellent secondary example of the show's de-emphasizing of sexual identity categories. While Vanessa's narrative incorporates heterosexual sex and is able to shift focus off the object preference and onto the types of supernatural powers that result from or prompt erotic encounters, Dorian Gray's character eliminates sexual markers altogether by making his sexuality impossible to define.

The character in Penny Dreadful is surprisingly true to the book original in Oscar Wilde's The Picture of Dorian Gray: he lives for experience and novelty. The show incorporates numerous hobbies for him, including portrait collecting, gramophone cylinder collecting, dancing, going to the theater (in a nod to the Sibyl Vane arc of the original), rat-baiting, and absinthe-drinking. Talking to Vanessa over dinner in S1 E6, he ticks off a long list of experimental philosophies he has tried: the Fabian society and vegetarianism, which he says was "hell; $[\ldots]$ transcendentalism, utilitarianism, Aestheticism, ludditism, Taoism, socialism [he

\footnotetext{
${ }^{20}$ From the play in S1 E4. Maud, the female lead, says, "But surely love is supernatural, a secret urge and not quite factual. A longing so deep and dark and rare, that only such as we can share" as the camera pans from Dorian to Vanessa.
} 
cringes] -that didn't stick." But for Dorian none "sticks," as variety is the spice of his life—and his life is so very long. The show thus demonstrates that Dorian's promiscuous pursuit of excitement is not only sexual—but it is also very sexual. There are wild parties with graphic nudity and sex acts and, we can guess, drugs; S1 E4 opens with a lavish orgy, but Dorian's bored expression make it seem like an average Tuesday night. The sex for Dorian might be the focus of the show, but it is more like a byproduct of his enigmatic personality, always seeking new sensations, which is caused by his immortal ennui-the supernatural aspect of his character.

If the sex is a focal point for Dorian and he is defined more directly by his sexual encounters, the show doesn't categorize him as bisexual or homosexual, he is portrayed as simply very-sexual. ${ }^{21}$ The nebulous relationship between Dorian's immortality and his erotic encounters creates a queer, indefinable allure for the audience: viewers appreciate Dorian's ability to easily move from hobby to hobby and from partner to partner (or partners), and come to understand that Dorian doesn't need to be sexually categorized; he just is sexual. One review describes him as having "unsubtle $[\ldots]$ omnivorous sexual appetites and scandalous inclinations, which are emphasized by his penchant for silk dressing gowns, orgies, leather trousers, and S\&M" (Murphy 144). Here, again, we have a laundry-list of things Dorian has tried, this time in front of viewers. His "omnivorous" passions are easily revealed as uncategorizable: if it were

${ }^{21}$ While I argue in Chapter II that book-Dorian's uncertain sexuality leaves him "queer," we might call show-Dorian "pansexual." I resist using this word because, by indicating the potential for any person to become the object of Dorian's desire, the term acts as a category of sexuality that does not necessarily encompass his kinks or other interests. Calling him "queer," like the original, would be more accurate in that it is more nebulous, but I prefer not to call him anything. 
possible to encapsulate his preferences or interests into just a few words of 'this' or 'not this,' he would be boxed in. Essentially, if it were possible to define Dorian's gender preference (heterosexual or homosexual) or even kink (leather or silk, S\&M or group sex), he would be limited, uninteresting. What the show does, then, in demonstrating the variety and scope of his sexuality, is to un-box and undefine sexual identity, demonstrating the potential of breaking away from rigid, normative categories.

Above all else, Dorian wants to remain undefined. Back at his home after dinner with Vanessa in S1 E6, he asks her to choose the music for the evening, and she understands she's being asked to set the mood. She asks, playfully, "Dorian Gray, who do you want to be?" And he replies, quite seriously, "Myself. Without limits," echoing her earlier speculation about what would happen if she would relax her composure. Just as Vanessa struggles to accept every part of herself, Dorian seems to struggle to express every part of himself-to live "without limits" in his social, sexual, and supernatural context. Such unbounded identity suggests the "morphic variability" of the abhuman (Hurley 3). Hurley says, "abhuman entities must of necessity confound traditional sexual identities. They are simultaneously male and female, masculine and feminine, heterosexual and homosexual — metamorphic as to sexed identity, indiscriminate as to both gendered behavior and object-choice" (150). As another potentially abhuman character in the show, then, Dorian does not fit neatly into human identity categories - either of the Victorian age or now. His "indiscriminate" choices are "omnivorous," "without limits," indefinable.

As I argue in Chapter II, this sexual indeterminacy makes Dorian queer in the original as well as in Penny Dreadful —Wilde himself says, "What Dorian Gray's sins are no one knows" (qtd. in Bristow xxiv). Penny Dreadful shows us Dorian's sexual sins, but does so in a way that they are nearly impossible to define because they are so promiscuous, prolific, and various. 
Thus, just as Dirk Schulz argues readers and critics should do for the original, the show allows indeterminacy and ambiguity to remain. "To define is to limit," says Lord Henry, the spokesman for much of the novel's queerness, and, "Knowledge would be fatal. It is the uncertainty that charms one. A mist makes things wonderful" $(165,173)$. Penny Dreadful embraces this fog of un-knowing, portraying Dorian as unbounded by sexual identity categories as defined by either his time or ours.

The conflict between knowing (by watching the explicitly erotic scenes of the show) and not-knowing (in the novel and in the show by inference: Dorian's sexual exploits go far beyond what we see) is certainly a product of Penny Dreadful's medium (visual) and Wilde's context (unspeakable). But the showing/not showing of erotic content is also an important area of inquiry for Victorianists and scholars of Neo-Victorian trends. Sexuality is "frequently cited as evidence of the gulf between the Victorians and us," according to Hadley, but mostly because modern viewers are interested in the idea of Victorian repression, believing that passion is "barely contained beneath high collars and stiff petticoats," and wanting to see the potential eruption of those passions (11-12). Modern viewers enjoy seeing debauchery like Dorian's for its spectacle because it is removed from their own repressive social contexts by more than a century. But the visibility of such sexuality and the undeniable attraction it has for viewers allow the show to question the repression still present in society. As viewers see Dorian embrace promiscuity and undefined variety in his historical Victorian context, they can perhaps also learn to accept it in the modern world.

Beyond the abstract potential the show creates for accepting things we cannot define, Penny Dreadful also demonstrates the importance of visibility for non-heterosexual identities in modern media. Dorian's infatuations not only add to the variety of his sexual partners, but they 
are also queer in and of themselves. The very first time we see Dorian, in S1 E2, his shirt gapes open seductively as he waits for consumptive Brona to arrive for an erotic photo shoot. Since we have already learned that Brona is a prostitute, even though we don't yet know who Dorian is, the scene is tensely sexual. Predictably, he is bored of the photography itself until she coughs blood, at which point Dorian perks up at the potential for novelty and immediately moves in for seduction. He says, "I've never fucked a dying creature before. Do you feel things more deeply, I wonder? Do you feel pain?" She replies, boldly, "Do you?" and he says, "Let's find out." Brona scratches him and then coughs blood in his face, foreshadowing his more violent erotic scene with Vanessa in S1 E6. His encounter with Brona is the first representation of blood play in the series, and because she is ill it also echoes gay barebacking and the known risk, sometimes intentionally pursued, of HIV transmission. ${ }^{22}$ This first scene with Dorian, then, establishes his promiscuous behavior in the sense of sexual promiscuity but also promiscuity of experience. The risk and the novelty are what appeal to him, and the visibility of his kinks on television operates the same way as other types of horror, attracting and repulsing simultaneously. Viewers allow themselves to watch, allow themselves to consider such fetishes or accept seeing them in others, because the show is removed from our modern context by more than a hundred years.

Other than these kinks, the Brona-Dorian erotic encounter is normative in many ways: they are white, cis, young, and the power dynamic favors Dorian not least because he has hired Brona. But Dorian's encounter with Angelique in Season 2 demonstrates a different kind of visibility predicated not only on queer sex, but also on gender identity and acceptance. Like

\footnotetext{
${ }^{22}$ For more, see Tim Dean's Unlimited Intimacy: Reflections on the Subculture of Barebacking,
} 2009. 
Sibyl Vane of the novel, who can multiply herself and become an/other on the stage, the Dorian of Penny Dreadful is attracted to Angelique, who is what we would call transgender. Here the show is making another interesting ahistorical interjection-men dressing as women to attract male clientele certainly existed in the $1890 \mathrm{~s},{ }^{23}$ but Dorian's reaction to Angelique provides the modern audience with a model for acceptance instead of disgust or rejection. Angelique indicates that she has had experience with more negative reactions, but Dorian recognizes and supports her, even publicly, until she unwittingly stumbles upon his secret portrait. ${ }^{24}$ To see Dorian's accepting, supportive relationship with a transgender woman reveals that "contemporary contemplation of Victorian sex [is] a dizzying hall of mirrors, in which it seems impossible to decide whether Victorian sexuality lies behind us in the dust, or whether, in their passionate struggles with sexual repression, the Victorians were somehow the harbingers of sexual self-realization" (Kucich and Sadoff xix). Thus, although the show's historical fiction genre could place the audience in a position of feeling superior for having made some kind of vague social progress, Dorian's acceptance of Angelique demonstrates that we can learn something from the ages before sex and gender identity became so fixed.

The specific nature of Dorian's sexual identity is de-emphasized in the show-not because the sex is unimportant, but rather because it is so frequent and so various that it resists categorization and becomes commonplace. His interest in variety, his collections and hobbies,

${ }^{23}$ The best-known example is perhaps the case of cross-dressing socialites and sex workers Ernest Boulton and Frederick Park (Stella and Fanny).

${ }^{24}$ When he kills her, it is because she knows his supernatural secret, not because of her gender expression or sexuality. 
his kinks, fetishes, and partners, all illustrate his quest to alleviate his boredom. The sex becomes just another item in a long list of things he has tried. In a review for Inverse.com, Lauren Sarner observes,

Penny Dreadful [is] far from the only show to depict kink, fetishes, or nonheteronormative sex, but it always treat[s] them nonchalantly. Recall Vanessa and Dorian's Season 1 blood play scene, or Vanessa's taxidermy fetish (it can't be coincidence that she had sex to the backdrop of a room full of stuffed dead animals multiple times). It also featured nonchalant sex between a man and a trans woman and sex between a couple in which both parties are above the age of 40 . Other shows feature fetishes or non-heteronormative intimacy, but rarely with this breadth or depth. (6)

And, alas, Sarner has forgotten one of the most non-normative sex scenes, between two adults over the age of 40 and enacting a dom/sub scene. Dorian's sex is certainly the most regular and the most emphasized, but as we can see, the show itself treats sex as a natural part of life in social, supernatural, and power relationships. Penny Dreadful may be guilty of sensationalism (sex sells TV shows), but it is also so saturated with explicitly erotic scenes that the viewer comes to accept them "nonchalantly."25

Dorian is a main player in the show's portrayal of sexual liberation that could encourage viewers to consider their own twenty-first century repressions, but his Season 3 storyline is sadly

${ }^{25}$ It must be mentioned that rape remains, as it should, absolutely abhorrent. S3 E2 opens with a scene of nonconsensual bondage with implied rape ending in the murder of the very young victim of sex trafficking, but Dorian and Lily intervene before anything happens and kill all the men present for the spectacle instead. 
disappointing. After her resurrection, Dorian becomes infatuated with Lily for much the same reason he was initially attracted to Brona - she is between life and death; she is abhuman. He supports her quest for domination over men because, at least at first, it is framed as "ascendancy" over all mortals (S2 E10). At the end of Season 2 when they terrify Frankenstein by not dying after he shoots them both, Dorian quips, "I've experienced so many sensations over the years, but never one precisely like this. Complete supremacy." His thirst for variety is temporarily quenched as he has wild, immortal sex with Lily and even more blood play as part of a threesome. But his own dominating male position leads him to betray her-and his queer immortal nature - by capitulating to the status quo and trying to get her to submit and obey. It is when he rejects the radical potential for revolution that he fails as a character. He becomes unlikable to the audience and is left lonely again when Lily leaves him. With the sudden ending of the series, we are left wondering: does he become, ultimately, a sad symbol of (immortal) perpetuated patriarchy? Is he every conservative white cis gay boy, just out to have a good time, trying to alleviate his existential angst? Like his literary namesake, Dorian's radical potential as a liberated sex symbol is undermined when he attempts to reasserts normative ideologies.

\section{Conclusion: The Potential of Penny Dreadful}

In the introduction to their work on monsters across more than a century, Sharla Hutchison and Rebecca A. Brown say, "monsters cannot be contained by mediums or eras or modes" (3). The abhumans of Penny Dreadful cross from their original Victorian books into our modern age as a television show, but they remain monstrous. Even the invented protagonist, Vanessa Ives, comes from these roots of the gothic heroine, the abject, the transgressive woman to interact with our new millennium. They, and their meanings, cannot be contained by either 
their historical context or their new modern form. This Neo-Victorian multiplicity, like Hadley's "dual approach," means that the modern audience understands the distance between us and the Victorians, acknowledges the transferal of the characters from their original sources, but also sees how they comment on our own age; we can see that they are not "contained" by either specific context. The distance created by more than a century between their origins and the airing of Penny Dreadful thus allows viewers room to more comfortably consider revolutionary ideas about sexual identity and spirituality as foreign while potentially applying them to the familiar modern world.

Halberstam says, "the monster functions as a monster [...] when it is able to condense as many fear-producing traits as possible into one body" (Skin Shows 21). So, what do we do when the monster is the protagonist? We re-imagine and re-consider what the "fear-producing traits" are, we have sympathy for the monster, and we understand those traits as not necessarily the sum total of an individual. We can acknowledge that Vanessa's demon side is scary and terrible while seeing that it empowers her. We can see that her erotic encounters might trigger supernatural effects, but that they do not define her. We can understand that her queer failure presents a new option that "thinks in terms of the negation of the subject rather than her formation, the disruption of lineage rather than its continuation, the undoing of self rather than its activation" (Halberstam, QAoF 126). Even Dorian-who is a focal point for exploring what sexuality is and does and looks like_-even he encourages us to re-evaluate what the "monster" of the sexual deviant is by leaving his sexual identity undefined and undefinable. In these ways, Penny Dreadful uses its Victorian setting and characters to explore alternatives to the sexual binary and identity-markers of our time - the show provides a distanced, historical space where viewers can consider the ways sexuality and the supernatural interact. 
A final example is worth a quick look, though his origin (in The Wolf Man films of the 1940s $)^{26}$ and American reimagining make him slightly outside the scope of this larger project. Ethan Chandler has multiple on-screen sexual partners, but, like Vanessa, his supernatural lycanthropy and inward spiritual struggle are the main identifying characteristics that the show focuses on. Moreover, Ethan's sexual orientation or identity is never questioned, even after he has sex with Dorian. The audience is invited to see him first and foremost as a conflicted, selfhating werewolf, and never as bisexual or even as a straight man who once had gay sex. Ethan also closely mirrors Vanessa's struggle, as he mopes and sulks about the men he has killed when he has given in to his dark side but somehow maintains his image as a "good guy" with a good heart. In his final scene with Vanessa, Ethan says, "I have stood at the very edge. I have looked into the abyss. If I'd taken one more step, I would have fallen” (S3 E9). Like Vanessa, he is abhuman and abject, toeing the line between good and evil, occasionally slipping from one side to the other, but never fully embracing either part of his nature.

Though they both seem to embrace the dark and then the light at the last moment, Ethan's submission to his own "destiny" and his killing of Vanessa (after she tells him he must) are also a sort of queer failure. He gives in to fate and Vanessa's desire for death, thereby surrendering actual choice. Vanessa says, "My battle must end. You know that. Or there will never be peace on Earth. Let it end." Ethan pleads, “don’t ask it." But Vanessa only replies, "I don't have to" (S3 E9). Ethan does not have to answer the will-you or won't-you question. There is no question, and so no answer. Rather than demonstrating Ethan's careful consideration or

${ }^{26}$ Ethan also could be inspired in part by The Werewolf of London, but his real last name is revealed to be Talbot - the name of the lycanthrope in The Wolf Man. 
explaining the logic in killing the Mother of Evil for the greater good, the show portrays Ethan's action as inevitable, a sort of falling-away of the self and agency that reinforces the potential for such radical submission and failure of will.

Queer failure, then, is one ultimate message of the show. And like Ethan, the supernatural side of Vanessa is what the show focuses on, indicating that the sex is subordinate to or merely the catalyst for the greater struggles of good and evil or material and spiritual. Using the Victorian fascination with the supernatural and still-flexible sexual categories, Penny Dreadful demonstrates the potential for taking the emphasis off strictly categorized sexual identity and reconsidering the meaning of individual determination, even if it means refusal and failure. The show's genre assists in delivering this message through multi-layered uses of history and modernity, highlighting both our differences from and similarities to the Victorians. Our own "concerns" about issues such as identity, sexuality, and spirituality prompt viewers to transpose the explorations of the show into the real world, encouraging us, too, to de-emphasize sexual categories and allow for identity expressions, as Dorian or Vanessa would say, "without limits." 


\section{Epilogue: Have a Cigarette}

\section{What I Did}

In the preceding chapters, I have considered a variety of late Victorian expressions of sexuality and spiritualism. In Chapter I, I explore the ways Teleny portrays Des Grieux's entry into Warnerian gay counterpublic through his telepathic connection with the eponymous pianist. Their mystical bond, which allows them to share visions across time and space, supports their queer erotic relationship as not only acceptable, but perhaps more meaningful than a normative partnership. Des Grieux make a clear shift to a gay identity, but Dorian Gray's desires are various, so Chapter II uses the queer multiplicity in The Picture of Dorian Gray to examine the promiscuous identity of its titular character. Dorian operates outside chrononormativity, and his supernatural immortality fuels his aberrant desires. While Chapters I and II (and IV) suggest the benefits of metaphysical elements in non-normative erotic relationships, Chapter III turns to consider how such a powerful combination could serve as a warning. I argue that The Beetle is ostensibly a cautionary story about the dangers of mesmerism and its associated sexual undercurrents, but that the warning falls short; "magic" and queer desires survive the novel and continue circulating in London. In addition to their work, Chapter IV looks at the life and writing process of Michael Field, and I conclude that their dedicated lesbian partnership is bolstered by their collaboration and paganism. The resulting relationship, based in sex, spirituality, and art, is what I call "aesthetic marriage." Finally, Chapter V makes a leap forward in time to consider the Neo-Victorian television show Penny Dreadful and how it continues to negotiate sexual identity with spirituality using a re-imagined historical setting. Rather than focusing on sexual orientation, the show's portrayal of Vanessa Ives highlights her supernatural 
abilities, and likewise Dorian Gray's promiscuity. I argue that this shift in emphasis allows viewers to reconsider the importance of sexual identity in normative modern ideologies.

This project argues that fin de siècle navigations of emerging categories of sexual identity were partially expressed in literary representations of supernatural connections, transformations, events, and practices. In tracing these themes across five chapters, I build on sexuality and queer foundations by such scholars as Foucault, Halberstam, and Warner along with New Historicist scholarship about spiritualism in the nineteenth century to examine the connections between aberrant erotic desires and alternative forms of spirituality. I have attempted to prove that queer sexual identities and acts, unspeakable, unfixed, and nebulous in the late Victorian years, were supported, represented, and navigated in these works through the use of the supernatural, demonstrating the importance of spiritualism and sexual desire in non-traditional identity and relationship building.

\section{What I Didn't Do}

There are a number of things the current project necessarily neglects in the interest of focus and space. The most obviously neglected theme is, perhaps, class. Most scholars do not directly address questions of class as related to the Victorian spiritualism movements, instead indirectly indicating certain professions, locations, and groups who were involved. Mesmerism, for example, was frowned upon unless undertaken by a medical professional who was paid for his services. This necessarily frames the practice, then, as one only performed by educated physicians on subjects who could afford to pay. Alison Winter, though, notes that as hypnosis gained popularity, its simple application "allowed anyone with a servant or a curious friend to experiment," to the extent that it became "ubiquitous" in London (57). Janet Oppenheim 
explains that Spiritualism was similar: some types had hierarchies akin to normative religious institutions, but spiritualist practices were so diverse that class is difficult to concisely discuss. ${ }^{1}$ It is similarly difficult to trace aberrant sexual encounters across classes because although practices, risks, and expressions might vary, homoerotic desires are not relegated to any specific social group. In both cases, as with most themes, those with money and power are able to write history: big names like Oscar Wilde spark public scandal, while a poor sodomite may be shunned by his neighbors but never make the news. Records of involvement, then, are necessarily biased - and for this reason it is doubly hard to discuss women's same-sex desires, especially with regards to class. The preceding chapters largely skirt class because it is a question investigated by others more directly concerned with the field, with more space to devote to such necessary nuance.

The most obviously neglected texts are, perhaps, a number of other canonical or nearcanonical authors and works that incorporate or even focus on the supernatural, in which aberrant sexual desires could, perhaps, be read. Vampire stories provide an excellent example, as many critics read the bite and transferal of blood to be sexual. Bram Stoker's Dracula (1897) is contemporaneous with the texts I examine, and could certainly provide additional evidence for the themes I trace, and it would be interesting to evaluate Varney the Vampire (1845-47) as a predecessor published during the height of hypnotism's popularity. The Gothic revival at the end of the Victorian era would be a rich field for similar supernatural tales, especially coupled

\footnotetext{
${ }^{1}$ See Oppenheim's The Other World for more, including sections on “Amateurs and professionals" (7), “The professional middle class" (28), “The industrious working class" (39), and "Organizers and societies" (49).
} 
with the New Woman and reshaped as the Female Gothic. ${ }^{2}$ Many scholars discuss spiritualism and/or sexuality in gothic texts. Though the Gothic is not my primary focus here, such references came up often in my research for the current project and I could easily shift my thesis to be Gothic-specific. Such genre-specific studies could also shift toward twentieth- and twentyfirst-century fantasy, where we generally find more recent clear examples of the supernatural and paranormal in non-human races and magic of various kinds.

The full scope of Victorian texts should not be neglected, though I have chosen works from just a few decades at the fin de siècle; as I discuss in Chapter III, Mesmer came to fame in the 1770s and ' 80 s, and interest in "hypnotism" was revived in the 1840s, so examination of mid-Victorian texts including the supernatural would certainly be reasonable. Dickens, for example, was famously interested in mesmerism and "learned to produce the trance himself" (Winter 52). Evidence for his personal belief in spiritualism can be found in the dream scene of Oliver Twist, the premise of A Christmas Carol, and his last, unfinished work, The Mystery of Edwin Drood. Any discussion of Dickens would bring with it a much-needed evaluation of the influence of class on spiritualism. Charlotte Brontë and Wilkie Collins, of course, also incorporate hints of strange occurrences like telepathy and hypnotism, as do a number of other, less-canonical authors. The problem with extending the study of spirituality and sexuality back toward mid-Victorian literature is the changing landscape of sexual identity and aberrant desire. The fin de siécle is uniquely situated in a time of flux and uncertainty, after legal, medical, and scientific considerations of sexological categories had begun, but before the binaristic

\footnotetext{
${ }^{2}$ The "Female Gothic" is a genre first named and defined by Ellen Moers in 1977 and since studied and expanded by many scholars.
} 
understanding of heterosexuality and homosexuality had taken root in common ideology. Thus, any evaluation of earlier works containing erotic desires and paranormal events would need to take into account the different contextual situation.

Other late-Victorian texts could still yield interesting and complementary readings of sexuality and spiritualism, though. In addition to Dracula, Vernon Lee's short stories of femmes fatale in Hauntings (1890) demonstrate the power of the irresistible erotic attraction of a series of mysterious women. Many of these objects of desire are unobtainable, resulting in an infatuation cut short, often by supernatural means. Though most of her stories center on heterosexual desire, Lee was a lesbian, and much of her writing as a male protagonist worshipping the female form reflects her own adoration of her lover, Kit Anstruther-Thomson. ${ }^{3}$ Furthermore, the failure of heterosexual love in the stories makes a noteworthy comment on Lee's opinion of the efficacy of those partnerships.

Beyond the direct address of sexuality and spiritualism, though, a number of related themes have become apparent as I have worked through the research and formulation of the current project, and in the interest of focus it has also been necessary to minimize these connections here. Though I only discuss Orientalism at length in Chapter III, it recurs throughout many of the selected texts, and has been the subject of much critical inquiry. While most clearly seen in The Beetle, Orientalism surfaces in Teleny, The Picture of Dorian Gray, and

\footnotetext{
${ }^{3}$ Even without this kind of biographical information, the stories of Hauntings are obviously queer. For a heavily contextualized queer reading, see Ardel Haefele-Thomas's “In Defence [sic] of Her Queer Community: Vernon Lee's Coded Decadent Gothic" in Queer Others in
} Victorian Gothic (U of Wales P, 2012). 
Penny Dreadful as well. Teleny is Hungarian, his first shared vision with Des Grieux is of Alhambra and Egypt, and the furnishings and décor in Teleny's room (where there is a lamp "from some Byzantine church or some Eastern synagogue") and the orgy scene (in which men are draped lewdly over "Persian and Syrian divans" like in brothels of "the wanton East") are Oriental, demonstrating the theme's importance in the novel in myriad ways $(5,15,96,122)$. Likewise, there are subtle details incorporated almost continually in Dorian that convey a general atmosphere of Orientalism, and we know of Wilde's interest because of evidence like Salomé and his own collection of blue china. ${ }^{4}$ As I establish in Chapter III, the subtext of homoeroticism in Orientalism was so widespread that it would have been understood by (some) contemporary readers of these texts. By incorporating Orientalism, then, Teleny and Dorian rely on such connotations to convey meaning without speaking it.

Penny Dreadful also thoroughly incorporates Orientalism in its main plot points: Vanessa is a manifestation of Amunet, ancient Egyptian goddess, and her struggle against evil is initially framed as a struggle to thwart an ancient Egyptian taboo against Amunet joining with the god Amun-Ra. As in The Beetle, the Oriental threat is already within London. Moreover, Ferdinand Lyle, a main character, is an Egyptologist introduced to the story to translate hieroglyphics. His office at the British Museum is fantastic, as imported artifacts, scrolls, and other Egyptianlooking detritus clutters every flat surface. The set design choices demonstrate the paradox of bringing the Orient into England, making the foreign into the local. Lyle is doubly important to consider because he has homoerotic desires, highlighting that element of Orientalism for

\footnotetext{
${ }^{4}$ For more, see "Oscar Wilde in Japan: Aestheticism, Orientalism, and the Derealization of the Homosexual" in Jeff Nunokawa's Tame Passions of Wilde.
} 
viewers. In Episode 6 of Season 3, Lyle tells Vanessa that he is leaving for Egypt "for appearance sake" because, "strictly entre nous, one has heard that Cairo is considerably more... accepting of my way of life." Thus, Orientalism's main representative, the Egyptologist, also struggles with his sexual identity and goes to Egypt to find respite. As W. C. Harris and Dawn Vernooy say, "to travel in the East was to seek, among other experiences, an escape from the rigidities of Western conventions - intellectual, spiritual, and, perhaps most often, sexual" (354). The use of Orientalism, then, is not isolated to The Beetle, and indeed, conveys many of the same loaded connotations in each of these texts as I establish in Chapter III.

In addition to the recurring theme of Orientalism, the importance of art and music cannot be ignored. Artistic concerns seem to be especially important for both spiritualism and sexuality studies. While I cover the importance of the aesthetic bond in Chapter IV on Michael Field, arts of various kinds make important contributions to the stories under question. Teleny, for example, is a pianist—and, more importantly, makes his first psychosexual telepathic bond with Des Grieux while playing a concert. Dorian becomes obsessed with the theater and Sibyl Vane for a large portion of Wilde's novel, and in Penny Dreadful, Dorian once again becomes the central figure for the arts, as he collects gramophone cylinders and portraits, attends plays, and dances frequently. Performance is doubly represented in the show as its medium draws attention to the artistic features of theme music, set, costume, and acting. As I discuss within the context of Michael Field's work, I do not think that the connections between the arts, sex, and spirituality are coincidence: Basil Hallward explains, the "subtle influence" of a great love can result in a new approach to art, with "all the passion of the romantic spirit, all the perfection of the spirit that is Greek[, and t]he harmony of soul and body" (Dorian 12-13). 


\section{Where it Goes From Here}

As I have now identified the things that fell outside the scope of the current work, it is logical to look ahead to potentially filling in these missing pieces and expanding my thesis to incorporate new texts and ideas as well. Lee's Hauntings and further exploration of Orientalism or art clearly offer new roads of possibility. Similarly, Hellenism may provide a field for exploration; as I discuss in Chapter IV, Hellenism, like Orientalism, incorporates undercurrents of both alternative sex and spiritualism (in paganism). Walter Pater's Marius the Epicurean provides a foundational starting point, and has been widely discussed by scholars already. ${ }^{5}$ Other texts like Anthony Trollope's “A Ride across Palestine" may be useful, as, indeed, will Lee's "Dionea." Trollope's story follows a mysterious pair of companions on a long desert pilgrimage across the Holy Land and traces the indescribable attraction between the two menuntil, we find, one of the "men" was a cross-dressing woman. "Dionea," like many of Lee's stories, uses a mysterious woman (this time appearing out of the sea after a shipwreck) to lure admirers to their doom. It is slowly revealed that Dionea is a manifestation of an ancient Greek goddess. These works, then, continue the themes of Orientalism and Hellenism in new directions: the sexual chemistry between the two "men" in Trollope is tied to their Oriental journey, a spiritual pilgrimage. Lee resurrects an ancient figure to demonstrate the erotic irresistibility of Woman, tying divinity to sexuality and, ultimately, death.

The abovementioned theme of music or the arts could also be extended in the directions of sexuality and spiritualism. For example, "The Lost Stradivarius" by J. Meade Falkner (1895) follows a young man's descent into madness as he discovers a Stradivarius violin and it begins to

\footnotetext{
${ }^{5}$ See, for example, Linda Dowling's Hellenism and Homosexuality in Victorian Oxford.
} 
haunt his life - he cannot stop playing a mysterious song and seems to be transported through time. The homosocial school environment and John Maltravers's obsession with the ghostly previous owner of the violin could be read as homoerotic. As in many of Lee's stories, the combination of music, magic, and queer obsession end in disaster, so perhaps the combination of sexuality and spiritualism is fatal unless desire is fulfilled.

Expanding my study to include France, one of the most famous mesmeric novels is George Du Maurier's Trilby (1895), which incorporates hypnosis and queer themes (such as the feminization of Little Billee), and the plot centers on the art world of Bohemian Paris and Trilby's singing performances. Expanding my study into the twentieth century a bit farther, E. M. Forster's Maurice (written 1913-1914, published 1971) includes connections between the (Hellenic) nude statuary at the British Museum and his homosexual desires and hypnosis. ${ }^{6}$ These texts both struggle with (sexual) identity as socially constructed and embraced (Trilby) or initially rejected (Maurice), and use the supernatural to navigate constructions of self.

Finally, echoing my fifth chapter on Penny Dreadful, I could expand the project to include other twenty-first century works in a variety of mediums. The 2002 film adaptation of Anne Rice's Queen of the Damned, for example, uses contemporary rock music as the inspirational force that awakens Lestat and Akasha from centuries-long slumber, unleashing their supernatural forces in a very eroticized way. To be more precise, a flashback shows Lestat partially waking Akasha soon after his own conversion by playing the violin to her while she

\footnotetext{
${ }^{6}$ Indeed, the Classical statuary collection at the British Museum is a recurring symbol of the homoerotics of Hellenism, and a touchstone for multiple authors. See Matt Cook's various work on the geography of homosexuality in London.
} 
sleeps in stone. As an immortal ancient Egyptian figure, Akasha embodies the eroticism of both Orientalism and the Gothic femme fatale along with the deepest vampiric magic. Lestat's rock music energizes her and stirs both her erotic and destructive desires. In this case, music is the catalyst for exploring how Lestat and Akasha express sexual desire and supernatural abilities. Like the Lee and Falkner just discussed, though, when the relationship ends, it leads to Akasha's downfall.

I am especially interested in development in this last direction, toward twenty-first century texts in a variety of genres, to tease out the ways we are still navigating sexuality using spiritualism or the supernatural. With a Modernist stop at Woolf's Orlando, I could proceed to the fantasy and science fiction of the mid-twentieth century and on to Neo-Victorian works of recent years by such writers as Sarah Waters and A. S. Byatt. As mentioned above, fantasy novels have become the places we are accustomed to looking for the supernatural, and I would argue that looking to science fiction is a logical progression from seeking the unexplainable paranormal to the unexplainable (because not yet understood) capabilities of science. Some of these texts undo the transition from fantasy to science and use a futuristic setting to make sex magical again. Ursula K. LeGuin's The Left Hand of Darkness (1969), for example, follows a universe-travelling ambassador to a planet populated by humans who are ambisexual unless they are in kemmer, a period of fertility. Such bodily transformation echoes the Beetle's ability to transform and shift between genders. In LeGuin's novel (spoiler), the ambassador learns to understand the "magic" of the ambisexuals and develops a very intimate bond with one of them. Sexual identity in LeGuin's contemporary context is radically different from the fin de siécle texts considered here, as sex and gender binaries were firmly entrenched by the 1960s, so LeGuin's novel is doing radical "what if?” exploration by asking readers to consider a world 
where gender is neutral by default because sex differences are variable and temporary. By encouraging readers to adjust to the ambisexual characters of Left Hand of Darkness using the ambassador's point of view, LeGuin also shows her audience that it is possible to live in a world without strict gender norms or strictly gendered sexual preferences.

In an even more extreme example of queer sex and mysterious science (fiction), Octavia E. Butler's Lilith's Brood Series (1987-89) explores what would happen if an alien race saved humanity, but in return demanded human mates to collect our DNA and hybridize it with their own. In the three books (Dawn, Adulthood Rites, and Imago), humans cannot understand the mystical aliens' motivations, bodies, or purpose on Earth, and the aliens can do seemingly magical things like make walls move, alter genes, and fly in giant, living ships. Armed with such a loose definition of "supernatural," I could examine how Butler explores the mystical union of different bodies in alien-human sexual encounters. I suspect that the overarching message of the series is that it will take the supernatural (in the sense of extraterrestrial) to remind humans that sex partners need not fit into rigid categories and that sex can be a sublimely connective experience.

Quite beside the point of this project, I am also interested in applying a similar lens to heterosexuality and the supernatural, perhaps as a second book or series of articles. Some of the texts mentioned above would be better read "straight" (e.g. Jane Eyre), but the spiritual element of sex is nevertheless important. Using Waisbrooker's theory of sexual evolution (discussed here in several chapters), even erotic encounters between opposite-sex partners can be spiritually enlightening. The recent wave of "supernatural romance" erotic novels demonstrates the abject 
appeal of using abhuman partners to explore a variety of sex acts. ${ }^{7}$ The lasting cultural fascination with vampires is also evidence of such interest.

In addition to spending more time addressing Orientalism, Hellenism, and the arts, my motivation in moving the conversation into the twenty-first century is to expand the critical intersections of sex and the supernatural so that two of the deepest of human intellectual instincts can continue to speak together. As the preceding chapters argue, the sexual and spiritual elements of these relationships cannot be separated. Some types of paranormal connections, like telepathy in Teleny or the collaboration and paganism of Michael Field, strengthen and support queer relationships to parallel or even surpass normative couplings. Some supernatural elements, like Dorian Gray's portrait (in both Wilde and Penny Dreadful) encourage or allow the queer erotic desires to exist. Other forms of mysticism, like the Beetle's mesmeric abilities or Michael Field's connection to Sappho across time, operate as vocabularies for opening the possibility of queer desires. In the twenty-first century, sexual identity categories have solidified, but we can still continue to make room for new expressions and explorations of desire by considering the role of the supernatural.

\footnotetext{
${ }^{7}$ I have read several of these novels, including Aline Hunter's Omega Mine series about animal shapeshifters and vampires. Plot twist, loving a human is taboo but the novels center on such couplings anyway! In these books in particular, lifetime monogamy is fetishized along with mutable, animalistic bodies.
} 


\section{Works Cited}

Amis, Kingsley, Lindsay Clarke, Lawrence Norfolk and Nigel Williams. "Time Magic and the Counterfactual Imagination." Romances of the Archive in Contemporary British Fiction, edited by Suzanne Keen, U Toronto P, 2001, pp. 132-153.

Arenstein, Seth. “A Dreadful Delight.” Review of Penny Dreadful, created by John Logan. Cablefax Daily, 9 May 2014, pp. 1-3.

Bauer, Heike. English Literary Sexology: Translations of Inversion, 1860-1930. Palgrave Macmillan, 2009.

Beckson, Karl. "The Dance of the Occult Mysteries." London in the 1890s: A Cultural History, Norton, 1992, pp. 317-44.

Boone, Joseph Allen. The Homoerotics of Orientalism. Columbia UP, 2014.

---. "Vacation Cruises: Or, the Homoerotics of Orientalism." PMLA, vol. 110, no. 1, 1995, pp. 89-107.

Bristow, Joseph. Introduction. The Picture of Dorian Gray, by Oscar Wilde, 1891, Oxford UP, 2006, pp. ix-xlii.

Cavaliero, Glen. The Supernatural and English Fiction. Oxford UP, 1995.

Cohen, Ed. Talk on the Wilde Side: Toward a Genealogy of a Discourse on Male Sexualities. Routledge, 1993.

Cook, Matt. “'A New City of Friends': London and Homosexuality in the 1890s.” History Workshop Journal, vol. 56, 2003, pp. 33-58.

Dean, Tim. Unlimited Intimacy: Reflections on the Subculture of Barebacking. U Chicago P, 2009. 
Dellamora, Richard. Masculine Desire: The Sexual Politics of Victorian Aestheticism. U North Carolina P, 1990.

Donoghue, Emma. We Are Michael Field. Absolute P, 1998.

Dowling, Linda. Hellenism and Homosexuality in Victorian Oxford. Cornell UP, 1994.

Ehnenn, Jill R. "Looking Strategically: Feminist and Queer Aesthetics in Michael Field's 'Sight and Song." Victorian Poetry, vol. 43, no. 1, 2005, pp. 109-154.

---. Women's Literary Collaboration, Queerness, and Late-Victorian Culture. Ashgate, 2008.

Evangelista, Stefano. British Aestheticism and Ancient Greece: Hellenism, Reception, Gods in Exile. Palgrave Macmillan, 2009.

---. "'Lovers and Philosophers at Once': Aesthetic Platonism in the Victorian 'Fin de Siècle.” The Yearbook in English Studies, vol. 36, no. 2, 2006, pp. 230-244.

Field, Michael. Long Ago. Thomas B. Mosher, 1897.

---. Michael Field, the Poet: Published and Manuscript Materials. Edited by Marion Thain and Ana Parajo Vadillo, Broadview, 2009.

---. Works and Days. Edited by Thomas Sturge Moore, D. C. Moore, J. Murray, 1933.

Finn, Michael R. Hysteria, Hypnotism, the Spirits, and Pornography: Fin-de-Siécle Cultural Discourses in the Decadent Rachilde. U of DE Press, 2009.

Foucault, Michel. The History of Sexuality, Volume 1: An Introduction. Vintage, 1990.

Freccero, Carla. Queer / Early / Modern. Duke UP, 2006.

Freeman, Elizabeth. Time Binds: Queer Temporalities, Queer Histories. Duke UP, 2010.

Geary, Robert F. The Supernatural in Gothic Fiction. Edwin Mellen Press, 1992.

Gould, Stephen Jay. Bully for Brontosaurus: Reflections in Natural History. Norton, 1991. 
Gray, Robert, and Christopher Keep. “An Uninterrupted Current: Homoeroticism and Collaborative Authorship in Teleny.” Literary Couplings: Writing Couples, Collaborators, and the Construction of Authorship, edited by Marjorie Stone and Judith Thompson, U of Wisconsin P, 2006, pp. 193-208.

Hadley, Louisa. Neo-Victorian Fiction and Historical Narrative: The Victorians and Us. Palgrave, 2010.

Haggerty, George E. Queer Gothic. U of Illinois P, 2006.

Halberstam, Jack. The Queer Art of Failure. Duke UP, 2011.

---. "Queer Temporality and Postmodern Geography." In a Queer Time and Place: Transgender Bodies, Subcultural Lives, NYU Press, 2005, pp. 1-21.

---. Skin Shows: Gothic Horror and the Technology of Monsters. Duke UP, 1995.

Harris, W. C., and Dawn Vernooy. ““Orgies of Nameless Horrors': Gender, Orientalism, and the Queering of Violence in Richard Marsh's The Beetle.” Papers on Language \& Literature, vol. 48, no. 4, 2012, pp. 339-381.

Holmes, Frederick. "The Historical Imagination and the Victorian Past: A. S. Byatt's Possession.” English Studies in Canada, vol. 20, no. 3, 1994, pp. 319-33.

Hurley, Kelly. The Gothic Body: Sexuality, Materialism, and Degeneration at the Fin de Siècle. Cambridge UP, 1996.

Hutcheon, Linda. A Poetics of Postmodernism: History, Theory, Fiction. Routledge, 1988.

Hutchinson, Sharla, and Rebecca A. Brown. Introduction. Monsters and Monstrosity from the Fin de siècle to the Millennium, edited by Hutchinson and Brown, McFarland \& Co, 2015, pp. 1-11.

Hutton, Patrick. History as an Art of Memory. UP of New England, 1993. 
Hyde, H. Montgomery. The Cleveland Street Scandal. W. H. Allen, 1976.

---. A History of Pornography. Farrar, Straus, and Giroux, 1965.

Kaplan, Morris B. Sodom on the Thames: Sex, Love, and Scandal in Wilde Times. Cornell UP, 2005.

Koestenbaum, Wayne. Double Talk: The Erotics of Male Literary Collaboration. Routledge, 1989.

Kristeva, Julia. Powers of Horror: An Essay on Abjection. Translated by Leon S. Roudiez, Columbia UP, 1982.

Kucich, John, and Dianne F. Sadoff. Introduction. Victorian Afterlife: Postmodern Culture Rewrites the Nineteenth Century, edited by Kucich and Sadoff, U of Minnesota P, 2000, pp. ix-XXx.

Lanska, Douglas J., and Joseph T. Lanska. "Franz Anton Mesmer and the Rise and Fall of Animal Magnetism: Dramatic Cures, Controversy, and Ultimately a Triumph for the Scientific Method." Brain, Mind and Medicine: Essays in Eighteenth-Century Neuroscience, edited by Whitaker H., Smith C.U.M., Finger S., Springer, 2007, pp. 301 320.

Lee, Vernon. Hauntings and Other Fantastic Tales. Broadview, 2006.

Leighton, Angela. Victorian Women Poets: Writing Against the Heart. UP of Virginia, 1992. Leighton, Mary Elizabeth. “'Hypnosis Redivivus': Ernest Hart, 'British Medical Journal,' and the Hypnotism Controversy. Victorian Periodicals Review, vol. 34, no. 2, 2001, pp. 104127.

---. "Under the Influence: Crime and Hypnotic Fictions of the Fin de Siécle." Victorian Literary Mesmerism, edited by Martin Willis and Catherine Wynne, Rodopi, 2006. 
Logan, John, creator. Penny Dreadful. Desert Wolf Productions and Neal Street Productions, 2014-2016.

London, Bette. Writing Double: Women's Literary Partnerships. Cornell UP, 1999.

Louis, Margot K. Persephone Rises, 1860-1927: Mythography, Gender, and the Creation of a New Spirituality. Ashgate, 2009.

Marcus, Sharon. Between Women: Friendship, Desire, and Marriage in Victorian England. Princeton UP, 2007.

Margree, Victoria. ““Both in Men’s Clothing’: Gender, Sovereignty and Insecurity in Richard Marsh's The Beetle." Critical Survey, vol. 19, no. 2, 2007, pp. 63-81.

Marsh, Richard. The Beetle. Edited by Julian Wolfreys, Broadview, 2004.

Mesmer, Franz Anton. Mesmerism: The Discovery of Animal Magnetism. Translated by V. R. Meyers, Soul Care, 2016.

Meyers, Jeffrey. "Wilde: The Picture of Dorian Gray (1891)." Homosexuality and Literature, 1890-1930. McGill-Queen’s UP, 1977, pp. 20-31.

Mitchell, Kate. Introduction. History and Cultural Memory in Neo-Victorian Fiction, by Mitchell, Palgrave, 2010, pp. 1-11.

Moers, Ellen. "Female Gothic." Literary Women: The Great Writers, Doubleday, 1977, pp. 9098.

Murphy, Bernice M. Review of Penny Dreadful Season 1, created by John Logan. The Irish Journal of Gothic and Horror Studies, vol. 13, 2014, pp. 142-6.

Neill, Anna. Primitive Minds: Evolution and Spiritual Experience in the Victorian Novel. Ohio State UP, 2013. 
Nunokawa, Jeff. Tame Passions of Wilde: The Styles of Manageable Desire. Princeton UP, 2003.

Olverson, T. D. Women Writers and the Dark Side of Late-Victorian Hellenism. Palgrave Macmillan, 2010.

---. “Libidinous Laureates and Lyrical Maenads: Michael Field, Swinburne and Erotic Hellenism." Victorian Poetry, vol. 47, no. 4, 2009, pp. 759-776.

Oppenheim, Janet. The Other World: Spiritualism and Psychical Research in England, 18501914. Cambridge UP, 1985.

Orrells, Daniel. Sex: Antiquity, and its Legacy. Oxford UP, 2015.

Prins, Yopie. “Greek Maenads, Victorian Spinsters.” Victorian Sexual Dissidence, edited by Richard Dellamora, U Chicago P, 1999, pp. 43-81.

---. Victorian Sappho. Princeton UP, 1999.

Rebry, Natasha. "Playing the Man: Manliness and Mesmerism in Richard Marsh's The Beetle." Gothic Studies, vol. 18, no. 1, 2016, pp. 1-15.

Rhys Morus, Iwan. "Worlds of Wonder: Sensation and the Victorian Scientific Performance." Isis, vol. 101, no. 4, 2010, pp. 806-816.

Roden, Frederick S. "Michael Field and the Challenges of Writing a Lesbian Catholicism." Michael Field and Their World, edited by Margaret D. Stetz and Cheryl A. Wilson, The Rivendale Press, 2007, pp. 155-162.

Said, Edward. Orientalism. Pantheon Books, 1978.

Sarner, Lauren. "The Late Penny Dreadful Leaves a Glorious, Gorgeous, Messy Legacy." Review of Penny Dreadful, created by John Logan. Inverse, 27 June 2016, 
https://www.inverse.com/article/17360-the-late-penny-dreadful-leaves-a-gloriousgorgeous-messy-legacy-in-its-wake. Accessed 30 Nov. 2017.

Schor, Hilary M. "Sorting, Morphing, and Mourning: A. S. Byatt Ghostwrites Victorian Fiction." Victorian Afterlife: Postmodern Culture Rewrites the Nineteenth Century, edited by John Kucich and Dianne F. Sadoff, U of Minnesota P, 2000, pp. 234-251.

Schulz, Dirk. Setting the Record Queer: Rethinking Oscar Wilde's The Picture of Dorian Gray and Virginia Woolf's Mrs. Dalloway. Transaction Publishers, 2011.

Sedgwick, Eve Kosofsky. Between Men: English Literature and Male Homosocial Desire. Thirtieth Anniversary ed., Columbia UP, 2016.

---. The Coherence of Gothic Conventions. Methuen, 1986.

---. Epistemology of the Closet. U California P, 2008.

Spurgeon, Caroline F. E. Mysticism in English Literature. Kennikat Press, 1970.

Stone, Marjorie, and Judith Thompson. "Contexts and Heterotexts: A Theoretical and Historical Introduction." Literary Couplings: Writing Couples, Collaborators, and the Construction of Authorship, edited by Stone and Thompson, U of Wisconsin P, 2006. 337.

Sturgeon, Mary. Michael Field. The Macmillan Co., 1922.

Tatar, Maria. "From Mesmer to Freud: Animal Magnetism, Hypnosis, and Suggestion." Spellbound: Studies on Mesmerism and Literature, Princeton UP, 1978, pp. 3-44.

Taylor-Brown, Emilie. “'She has a parasite soul!' The Pathologization of the Gothic Monster as Parasitic Hybrid in Bram Stoker's Dracula, Richard Marsh's The Beetle, and Arthur Conan Doyle's The Parasite." Monsters and Monstrosity from the Fin de siècle to the 
Millennium, edited by Sharla Hutchinson and Rebecca A. Brown, McFarland \& Co, 2015. 12-28.

Thain, Marion. Michael Field: Poetry, Aestheticism, and the Fin de Siécle. Cambridge UP, 2007.

Thain, Marion, and Ana Parajo Vadillo. Introduction. Michael Field, the Poet: Published and Manuscript Materials, by Michael Field, Broadview, 2009, pp. 23-51.

Thomas, Ronald R. "Specters of the Novel: Dracula and the Cinematic Afterlife of the Victorian Novel." Victorian Afterlife: Postmodern Culture Rewrites the Nineteenth Century, edited by John Kucich and Dianne F. Sadoff, U of Minnesota P, 2000, pp. 288310.

Teleny, or The Reverse of the Medal. Edited by Amanda Caleb, Valancourt, 2010.

Thurschwell, Pamela. Literature, Technology and Magical Thinking, 1880-1920. Cambridge UP, 2001.

Tyson, Nancy Jane. "Caliban in a Glass: Autoscopic Vision in The Picture of Dorian Gray." The Haunted Mind: The Supernatural in Victorian Literature, edited by Elton E. Smith and Robert Haas, The Scarecrow Press, 1999, pp. 101-121.

Vanita, Ruth. Sappho and the Virgin Mary: Same-Sex Love and the English Literary Imagination. Columbia UP, 1996.

Vicinus, Martha. “The Adolescent Boy: Fin-de-Siécle Femme Fatale?” Victorian Sexual Dissidence, edited by Richard Dellamora, U Chicago P, 1999, pp. 43-81.

---. “'Sister Souls': Bernard Berenson and Michael Field (Katharine Bradley and Edith Cooper)." Nineteenth-Century Literature, vol. 60, no. 3, 2005, pp. 326-354. 
Vuohelainen, Minna. “'The Key of the Street': Displacement, Transit, and Gothix Flux.” The Beetle. By Vuohelainen. U of Wales P, 2015. eBook.

Waldrep, Shelton. The Aesthetics of Self-Invention: Oscar Wilde to David Bowie. U of Minneapolis P, 2004.

Warner, Michael. Publics and Counterpublics. Zone Books, 2005.

Waters, Sarah. "'The Most Famous Fairy in History': Antinoüs and Homosexual Fantasy." Journal of the History of Sexuality, vol. 6, no. 2, 1995, pp. 194-230.

Weyant, Robert G. "Protoscience, Pseudoscience, Metaphors and Animal Magnetism.” Science, Pseudo-Science and Society, edited by Marsha P. Hanen, Margaret J. Osler, and Weyant, Wilfrid Laurier UP, 1980, pp. 77-114.

White, Chris. "“Poets and lovers evermore': the poetry and journals of Michael Field." Sexual Sameness: Textual Differences in Lesbian and Gay Writing, edited by Joseph Bristow, Routledge, 1992, pp. 26-43.

Wilde, Oscar. The Picture of Dorian Gray. Oxford UP, 2006.

Willburn, Sarah A. Possessed Victorians: Extra Spheres in Nineteenth-century Mystical Writings. Ashgate, 2006.

Willis, Martin, and Catherine Wynne. Introduction. Victorian Literary Mesmerism, edited by Willis and Wynne, Rodopi, 2006.

Winter, Alison. Mesmerized: Powers of Mind in Victorian Britain. U of Chicago P, 1998.

Wolfreys, Julian. Victorian Hauntings: Spectrality Gothic, the Uncanny and Literature. Palgrave, 2002. 